\title{
TREND ANALYSIS OF SELECTED WATER-QUALITY CONSTITUENTS IN THE VERDE RIVER BASIN, CENTRAL ARIZONA
}

By STANLEY BALDYS, III

U.S. GEOLOGICAL SURVEY

Water-Resources Investigations Report 90-4128

Prepared in cooperation with the ARIZONA DEPARTMENT OF ENVIRONMENTAL QUALITY 
U.S. DEPARTMENT OF THE INTERIOR

MANUEL LUJAN, JR., Secretary

U.S. GEOLOGICAL SURVEY

Dallas L. Peck, Director

For additional information write to:

District Chief

U.S. Geological Survey

Federal Building, Box FB-44

300 West Congress Street

Tucson, Arizona 85701-1393
Copies of this report can be purchased from:

U.S. Geological Survey

Books and Open-File Reports Section Federal Center, Building 810

Box 25425

Denver, Colorado 80225 


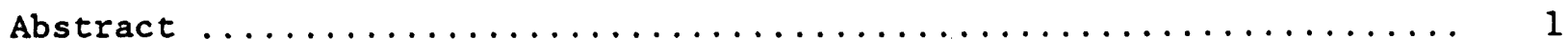

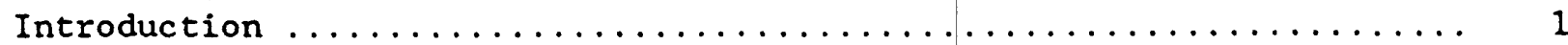

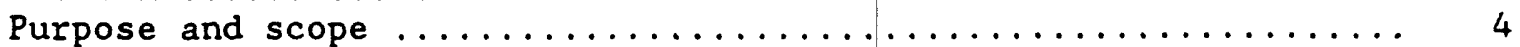

Previous studies ............................. 4

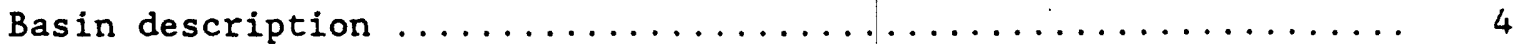

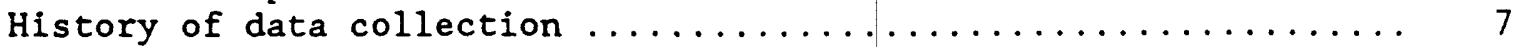

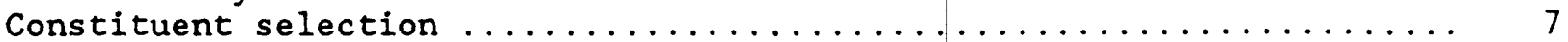

Summary statistics ............................ 11

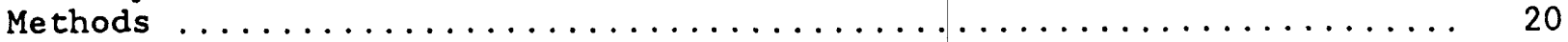

Ordinary least-squares regression analysis.............. 20

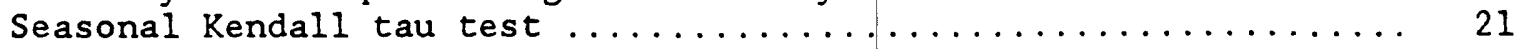

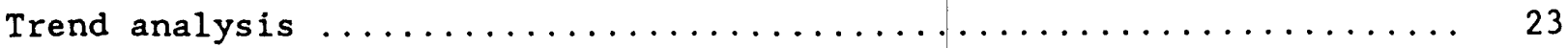

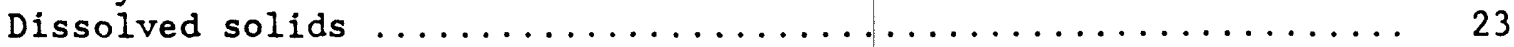

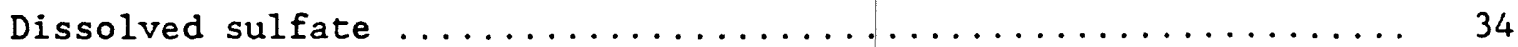

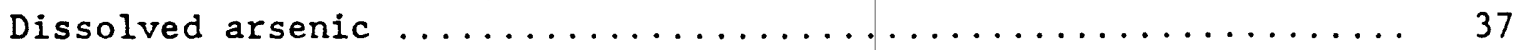

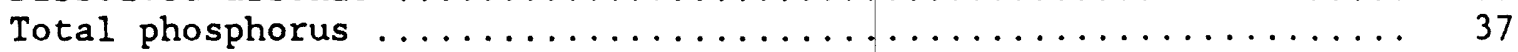

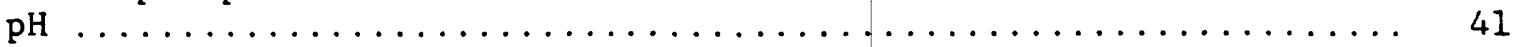

Total nitrite plus nitrate-nitrogen $\ldots \ldots \ldots \ldots \ldots \ldots \ldots \ldots \ldots \ldots \ldots$

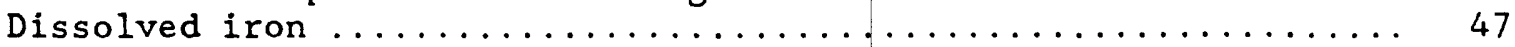

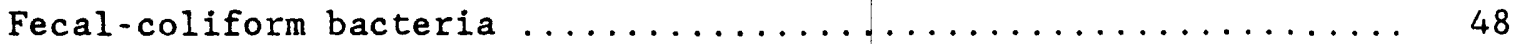

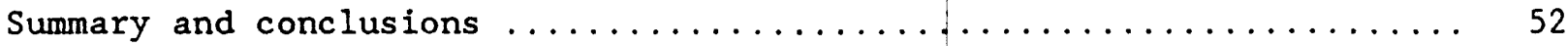

Selected references............................. 53

ILLUSTRATIONS

Page

Figure 1. Map showing location of study area............... 3

2. Schematic diagram showing location of major tributaries to the Verde River, data-collection sites, and mean daily discharge where data are available.............

3-19. Graphs showing:

3. Box plots of constituent concentrations.......... 16

4. Temporal trends in dissolved-solids concentrations using the ordinary least-\$quares regression

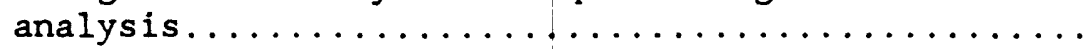

5. Temporal trends in discharge-adjusted dissolvedsolids concentrations using the seasonal Kendall tau test.

6. Temporal trends in dissolved-sulfate concentrations using the ordinary least-squares regression

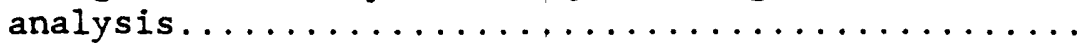




\section{ILLUSTRATIONS}

Figures 3-19. Graphs showing-Continued

Page

7. Temporal trends in discharge-adjusted dissolvedsulfate concentrations using the seasonal

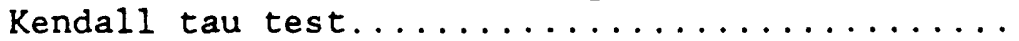

8. Temporal trends in dissolved-arsenic concentrations using the ordinary

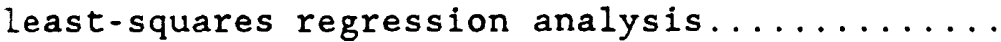

9. Temporal trends in discharge-adjusted dissolvedarsenic concentrations using the seasonal

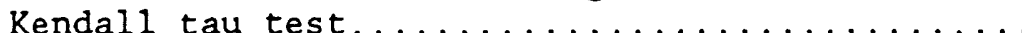

10. Temporal trends in total-phosphorus concentrations using the ordinary least-squares regression

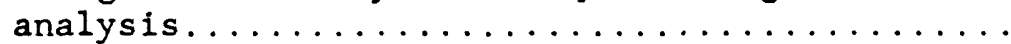

11. Temporal trends in discharge-adjusted totalphosphorus concentrations using the seasonal Kendall tau test....................

12. Temporal trends in $\mathrm{pH}$ concentrations using the ordinary least-squares regression analysis.....

13. Temporal trends in discharge-adjusted $\mathrm{pH}$ concentrations using the seasonal Kendall

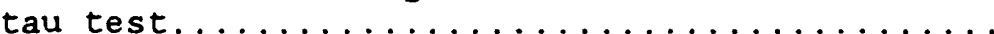

14. Temporal trends in total nitrite plus nitratenitrogen concentrations using the ordinary least-squares regression analysis............

15. Temporal trends in discharge-adjusted total nitrite plus nitrate-nitrogen concentrations using the seasonal Kendall tau test...........

16. Temporal trends in dissolved-iron concentrations using the ordinary least-squares regression

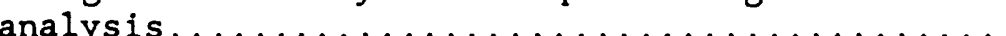

17. Temporal trends in discharge-adjusted dissolvediron concentrations using the seasonal Kendall

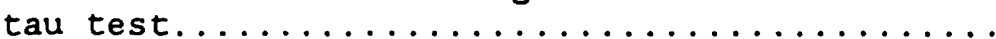

18. Temporal trends in fecal-coliform bacteria concentrations using the ordinary least-squares

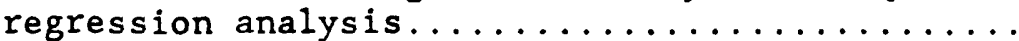

19. Temporal trends in discharge-adjusted fecalcoliform bacteria concentrations using the seasonal Kendall tau test. 
TABLES

Page

Table 1. Characteristics of water-quality data-collection

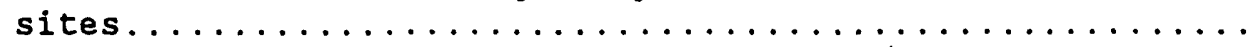

2. Periods of data collection for surface-water and water-quality study sites $\ldots \ldots \ldots \ldots \ldots \ldots \ldots \ldots \ldots \ldots$

3. Maximum contaminant levels and maximum allowable limits for selected constituents in water, Verde River basin,

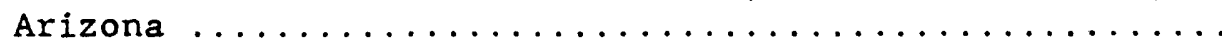

4. Summary statistics for water-quality data used in

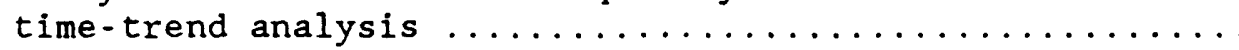

5. Results of ordinary least-squares regression analysis and seasonal Kendall tau test of water-quality data.......... 24

\section{CONVERSION FACTORS}

For readers who prefer to use the metric (International system) units, the conversion factors for the inch-pound units used in this report are listed below:

Multiply inch-pound unit

inch (in.)

foot ( $f t$ )

mile (mi)

acre

acre-foot (acre-ft)

cubic foot per second $\left(f t^{3} / s\right)$ degree Fahrenheit $\left({ }^{\circ} \mathrm{F}\right)$ $\underline{\text { By }}$<smiles>[13CH3]</smiles>

0.3048

1.609

0.4047

0.001233

0.02832

${ }^{\circ} \mathrm{C}=5 / 9\left({ }^{\circ} \mathrm{F}-32\right)$
To obtain metric unit

millimeter ( $\mathrm{mm}$ )

meter (m)

kilometer $(\mathrm{km})$

square hectometer $\left(\mathrm{hm}^{2}\right)$ cubic hectometer $\left(\mathrm{hm}^{3}\right)$ cubic meter per second $\left(\mathrm{m}^{3} / \mathrm{s}\right)$ degree Celsius $\left({ }^{\circ} \mathrm{C}\right)$

Sea level: In this report "sea level" refers to the National Geodetic Vertical Datum of 1929 (NGVD of 1929)-a geodetic datum derived from a general adjustment of the first-order level nets of both the United States and Canada, formerly called "Sea Level Datum of 1929." 


\section{TREND ANALYSIS OF SELECTED WATER-QUALITY CONSTITUENTS IN THE VERDE RIVER BASIN, CENTRAL ARIZONA}

\section{By}

Stanley Baldys, III

\section{ABSTRACT}

Temporal trends of eight water-quality constituents at six data-collection sites in the Verde River basin in central Arizona were investigated using seasonal Kendall tau and ordinary least-squares regression methods of analyses. The constituents are dissolved solids, dissolved sulfate, dissolved arsenic, total phosphorus, pH, total nitrite plus nitrate-nitrogen, dissolved iron, and fecal-coliform bacteria. Data collected from October 1976 to March 1987 for the eight constituents at the six sites were analyzed for temporal trends. The analysis also included data collected from 1968 to March 1987 at Wet Bottom Creek near Childs, a hydrologic bench-mark station, and from 1950 to March 1987 at Verde River below Bartlett Dam.

Increasing trends with time in dissolved-solids concentrations of 7 to 8 milligrams per liter per year at Verde River near Camp Verde were found at significant levels $(p \leq 0.0500)$. An increasing trend in dissolvedsulfate concentrations of 3.59 milligrams per liter per year was also found at Verde River near Camp Verde, although at nonsignificant levels $(p-0.2609)$. Arithmetic mean dissolved-solids concentrations at Verde River near Camp Verde, 403 milligrams per liter, and at other sites farther downstream on the Verde River, 285 to 328 milligrams per liter, were less than the 500 milligrams per liter recommended by the U.S. Environmental Protection Agency for drinking water. Statistically significant decreasing trends with time in dissolved-solids and dissolved-sulfate concentrations were found at Verde River above Horseshoe Dam for data collected from 1980 to 1987. These decreasing trends could be a naturally occurring change in temporal water-quality trends, although additional data need to be collected in the reach of the Verde River between the Verde River near Clarkdale site and Verde River below Tangle Creek above Horseshoe Dam site. Observed trends in the other selected inorganic constituents do not indicate the emergence of water-quality problems in the Verde River basin. Analyses of the eight water-quality constituents indicate nonvarying concentration levels after adjustments were made for seasonality and streamflow.

\section{INTRODUCTION}

The possible degradation of water quality in streamflow from the Verde River basin in north-central Arizona has become a major concern of local and State officials. Streamflow from the Verde River basin provides valuable recreational, agricultural, and domestic water supplies to 
residents of central Arizona. Most of this streamflow is allocated as a supply of drinking water for the rapidly growing Phoenix metropolitan area, which is downstream from the confluence of the Salt and Verde Rivers (fig. 1). Water from the Verde River is preferred over that from the Salt River as a public drinking-water supply because of lower water-treatment costs.

Large-scale recreational use and habitat for wildlife in the Verde River basin are made possible by water from the Verde River. Horseshoe Reservoir and Bartlett Reservoir, which have a combined storage capacity of 309,600 acre-ft behind Horseshoe and Bartlett Dams often are heavily used for recreation. Upstream from the reservoirs, the river provides sufficient moisture to maintain dense riparian vegetation on the adjacent flood plain, which serves as habitat for many types of wildlife. The Verde River provides favorable habitat for many types of aquatic organisms.

Water from the Verde River is used for agricultural purposes, primarily in Verde Valley. In recent years, conversion of land covered by natural vegetation to agricultural use has increased demand for river water. Water for agricultural use is diverted directly from the river and is also withdrawn from wells that are hydraulically connected with the river (OwenJoyce, 1984). Some of this water returns to the river as irrigation and livestock wastewater.

The population in the Verde River basin from Clarkdale to Camp Verde (fig. 1) has increased in the last two decades (Valley National Bank, 1988) and probably will continue to do so in the future. Although some industries have moved into the area, the main reason for the population growth is the region's appeal as a recreational and retirement area. Waterresource managers are concerned that recent population growth in the Verde River basin may be causing water-quality degradation of the Verde River through point and nonpoint sources. The population in the Phoenix metropolitan area, which is dependent on water supplies from the Verde River, also is increasing, and the demand for potable water supplies to keep pace with the population boom also is growing.

Water quality of the Verde River could also be degrading because of contaminants from mining operations near the town of Jerome that enter the Verde River upstream from the populated Camp Verde area. The Jerome area had large-scale mining activity during the early 1900's. The primary drainage for the Jerome area is Bitter Creek, which enters the Verde River downstream from the U.S. Geological Survey gaging station, Verde River near Clarkdale.

The U.S. Geological Survey, in cooperation with the Arizona Department of Environmental Quality, conducted this study of water-quality trends of selected chemical and biological constituents at sites in the Verde River basin to meet the following objectives:

- Detect emerging local or basinwide water-quality problems.

- Determine the effectiveness of regulatory actions on point sources.

- Determine the need for cause-and-effect studies. 


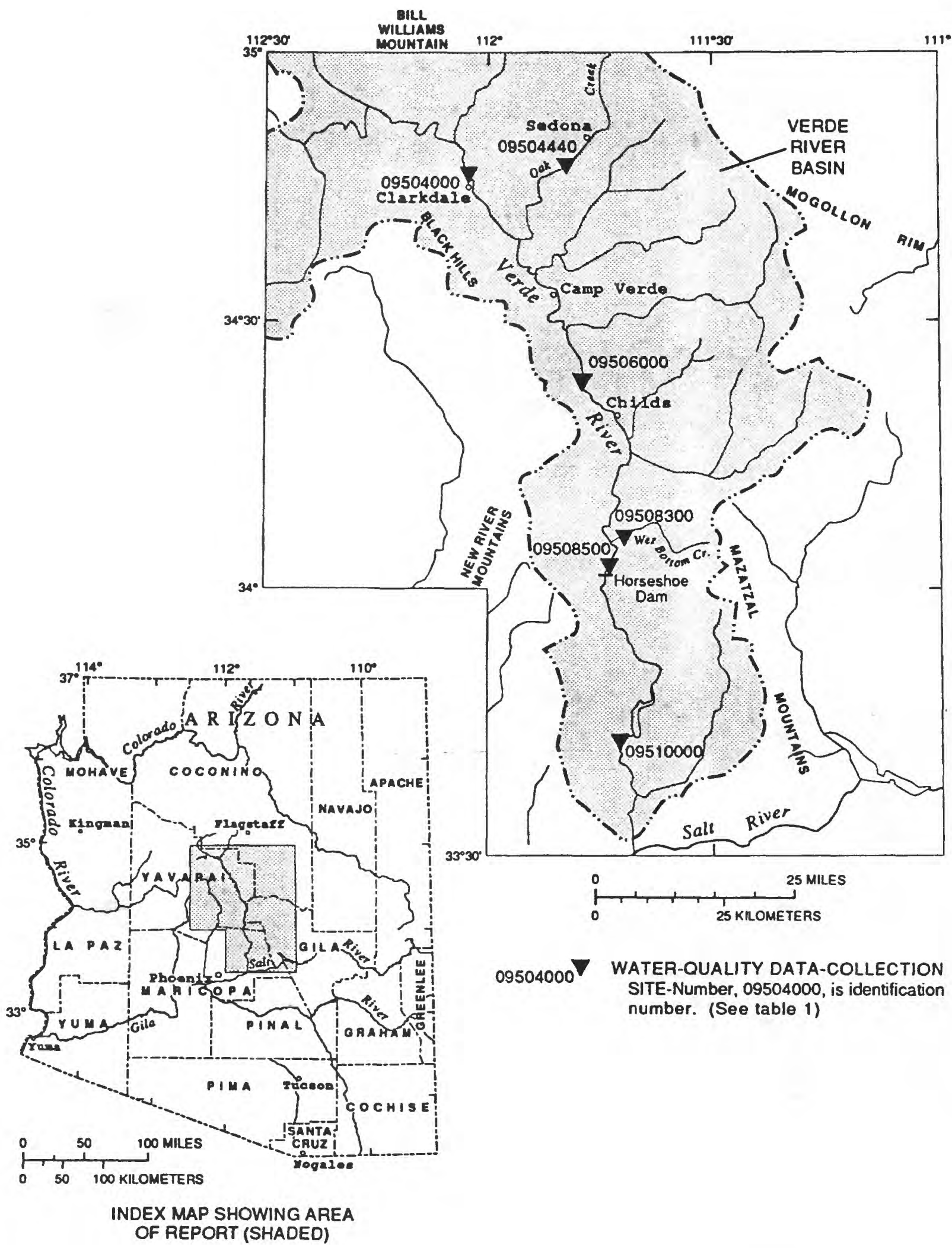

Figure 1.-Location of study area. 
- Recommend additional sites in the Verde River waterquality network to better define and effectively monitor emerging problems.

- Reduce or redirect sampling timetables or constituent coverage at existing sites on the Verde River.

\section{Purpose and Scope}

This report describes the temporal and areal variability of eight water-quality constituents at six water-quality data-collection sites in the Verde River basin. Selection of constituents was made on the basis of potential water-quality problems found in earlier investigations. Four of the sites are on the main stem of the Verde River from Clarkdale to $1.2 \mathrm{mi}$ downstream from Bartlett Reservoir (fig. 1). The other two sites, one each on Oak Creek and Wet Bottom Creek, are on tributaries to the Verde River.

Water-quality data used in this analysis are stored in the Arizona district's water-quality subsystem of the U.S. Geological Survey National Water Information System. Data analysis was accomplished using standard statistical software packages and programs written by personnel of the U.S. Geological Survey (Smith and others, 1982, p, 32).

\section{Previous Studies}

A report by Owen-Joyce and Bell (1983) presents a water-resources appraisal of the upper Verde River area and contains a summary of previous hydrologic and geologic studies concerning the Verde River basin. A later study of the stream-aquifer system in the Camp Verde area found increased levels of dissolved solids, sulfate, and arsenic in the Verde River resulting from ground-water recharge and return flow of irrigation wastewater (Owen-Joyce, 1984, p. 1).

The seasonal Kendall tau test applied to discharge-adjusted concentrations was used as the primary method of trend analysis in this study. This test is described by Kendall (1975), Hirsch (1982), Smith and others (1982), and Alley (1988). This method of trend analysis has been used in several hydrologic investigations, and the results are published in reports by Smith and others (1982), Goetz and others (1987), Buell and Grams (1985), and Smith and others (1987). The seasonal Kendall tau test also was applied to raw concentration data. The secondary method of trend analysis used in this study was the ordinary least-squares regression analysis (Alley, 1987).

\section{Basin Description}

The six water-quality data-collection sites in this study are in the Verde River basin (fig. 1). The altitude is 3,950 ft above sea level at the highest site, Oak Creek at Red Rock Crossing, and 1,572 ft at the lowest site, Verde River below Bartlett Dam (table 1). Altitudes in the Verde 
Table 1.-Characteristics of water-quality data-collection sites

\begin{tabular}{lcc}
\hline $\begin{array}{c}\text { Station name and number } \\
\text { (see figure I for location) }\end{array}$ & $\begin{array}{c}\text { Altitude, in feet } \\
\text { above sea level }\end{array}$ & $\begin{array}{c}\text { Drainage area, in } \\
\text { square miles }\end{array}$ \\
\hline $\begin{array}{l}\text { Verde River near Clarkdale } \\
\text { (09504000) }\end{array}$ & 3,500 & 3,520 \\
$\begin{array}{l}\text { Oak Creek at Red Rock Crossing } \\
\text { near Sedona (09504440) }\end{array}$ & 3,950 & 252 \\
$\begin{array}{l}\text { Verde River near Camp Verde } \\
\text { (09506000) }\end{array}$ & 2,890 & 3,024 \\
$\begin{array}{l}\text { Wet Bottom Creek near Childs } \\
\text { (09508300) }\end{array}$ & 2,320 & 36.4 \\
$\begin{array}{l}\text { Verde River below Tangle Creek, } \\
\text { above Horseshoe Dam (09508500) }\end{array}$ & & 5,872 \\
$\begin{array}{l}\text { Verde River below Bartlett } \\
\text { Dam (09510000) }\end{array}$ & 2,029 & 6,188 \\
\hline
\end{tabular}

River basin range from 9,256 ft at Bill Williams Mountain in the northwest to $1,572 \mathrm{ft}$ where the Verde River flows into the Salt River. The study area is bounded by the Mogolion Rim on the north and northeast, the Mazatzal Mountains on the east, and the New River Mountains and Black Hills on the south and west, respectively.

The Verde River is the main stream that drains the study area. A schematic diagram of the Verde River basin shows the location of major tributaries to the Verde River and water-quality data-collection sites (fig. 2). Major tributaries to the Verde River, in upstream to downstream order, are Bitter Creek, Oak Creek, Wet Beaver Creek, West Clear Creek, Fossil Creek, East Verde River, Wet Bottom Creek, Tangle Creek, Lime Creek, Deadman Creek, and Sheep Creek. Oak Creek and the East Verde River generally contribute the largest quantities of tributary flow to the Verde River. Ground-water recharge significantly augments streamflow in the Camp Verde area; less than 1 percent is septic-tank effluent (Owen-Joyce, 1984). The Verde Valley area does not have a municipal wastewater-treatment facility; therefore, wastewater is treated by small septic-tank and leachfield systems. Streamflow of the East Verde River is augmented by the addition of water from Blue Ridge Reservoir, which is in the Little Colorado River basin (Hjalmarson and Davidson, 1966).

The geology of the area is complex and is not described in this report. A description of the geology is available in Owen-Joyce and Bell (1983) and in geologic maps by the Arizona Bureau of Mines (Wilson and others, 1969).

The Verde Valley area has a favorable climate year round; hence, its popularity with retirees. The mean July temperature at Cottonwood is 


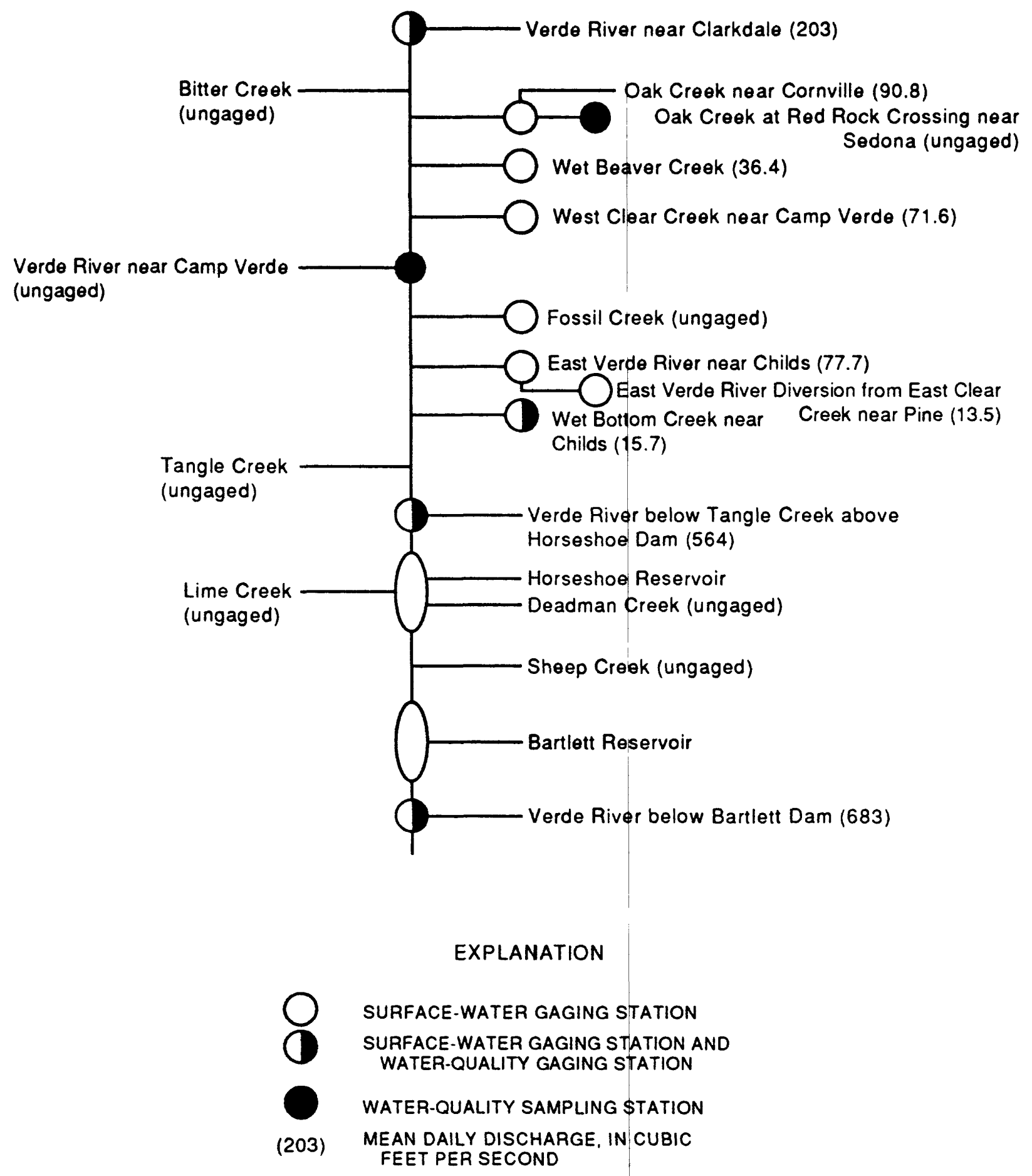

Figure 2.-Location of major tributaries to the Verde River, data-collection sites, and mean daily discharge where data are available. 
82.2 ${ }^{\circ} \mathrm{F}$, and the mean January temperature is $43.3^{\circ} \mathrm{F}$ (Sellers and others, 1985). Mean temperatures along the Verde River increase as altitude is lost. The mean temperature at Bartlett Dam is $90.6^{\circ} \mathrm{F}$ for July and $52.5^{\circ} \mathrm{F}$ for January (Sellers and others, 1985).

\section{History of Data Collection}

The U.S. Geological Survey collects water-quality samples for determination of various constituent concentrations and physical properties at six sites in the Verde River basin (table 1). The length of period sampled and frequency of sampling for each site varied considerably (table 2). Sampling generally was done quarterly at the Wet Bottom Creek site and monthly at the other sites.

Two sites, Verde River near Camp Verde and Verde River below Bartlett Dam, had changes in the locations of the sample-collection points. The Verde River near Camp Verde site is downstream from the Camp Verde metropolitan area and $9.7 \mathrm{mi}$ downstream from the mouth of West Clear Creek. Some samples referenced to this site were collected $1.8 \mathrm{mi}$ upstream from May 1980 to June 1981 because of access restrictions as a result of eagle nesting in the area. From 1950 through November 1980, water-quality samples at Verde River below Bartlett Dam were collected $500 \mathrm{ft}$ downstream from the dam. In December 1980, the data-collection site was moved to a point $2.1 \mathrm{mi}$ downstream from the dam. No other changes were made in the location of data-collection sites.

Mean dally discharges for the period of surface-water data collection and for the period of water-quality data collection were evaluated to determine if the two periods had similar discharges (table 2). Mean daily discharges for Verde River near Clarkdale and Wet Bottom Creek for the two periods were similar. At Verde River above Horseshoe Dam, mean daily discharge for the water-quality period was greater than that for the surface-water period. The reverse was true at Verde River below Bartlett Dam. Streamflow has been regulated by Bartlett Dam since February 5, 1939, and by Horseshoe Dam since November 15, 1945. Analysis of mean daily discharge data from the four sites where discharge data were collected indicates that the periods of water-quality sampling were fairly representative with respect to long-term discharge conditions.

\section{CONSTITUENT SELECTION}

The constituents for this study were selected from approximately 100 constituents sampled at each site. Trend analysis was performed on constituents that were (1) identified in previous studies with concentrations that exceeded or approached recommended Federal health standards (U.S. Environmental Protection Agency, 1976; 1986) and (2) indicative of inorganic and bacteriological water-quality problems. Many constituents do not readily conform to trend-analysis procedures; therefore, not all water-quality constituents could be analyzed for trends. The eight constituents selected for trend analysis in this study are dissolved solids, dissolved sulfate, dissolved arsenic, total phosphorus, pH, total nitrite plus nitrate-nitrogen, dissolved iron, and fecal-coliform bacteria. 
Table 2.- Periods of data collection for surface-water and water-quality study sites

\begin{tabular}{|c|c|c|c|c|}
\hline \multirow[b]{2}{*}{$\begin{array}{l}\text { station name } \\
\text { and number }\end{array}$} & \multicolumn{2}{|c|}{ Period of record } & \multicolumn{2}{|c|}{$\begin{array}{l}\text { Mean daily discharge, } \\
\text { in cubic feet per second }\end{array}$} \\
\hline & Surface water & $\begin{array}{c}\text { Ouality of } \\
\text { water }\end{array}$ & $\begin{array}{c}\text { Surface-water } \\
\text { period }\end{array}$ & $\begin{array}{c}\text { Qual ity-of-water } \\
\text { period }\end{array}$ \\
\hline $\begin{array}{l}\text { Verde River near } \\
\text { Clarkdale } \\
(09504000)\end{array}$ & $\begin{array}{l}6 / 1915-10 / 16 \\
5 / 1917 \cdot 7 / 21 \\
4 / 1965-1987\end{array}$ & $\begin{array}{l}3 / 1976-10 / 83 \\
10 / 1986-1987\end{array}$ & ${ }^{1} 202$ & 1223 \\
\hline $\begin{array}{l}\text { Oak Creek at Red Rock } \\
\text { Crossing near Sedona } \\
(09504440)\end{array}$ & None & $\begin{array}{l}10 / 1978 \cdot 10 / 83 \\
10 / 1986 \cdot 1987\end{array}$ & $\ldots \ldots$ & $\cdots \ldots$ \\
\hline $\begin{array}{l}\text { Verde River near } \\
\text { Camp Verde } \\
(09506000)\end{array}$ & None & $10 / 1978 \cdot 9 / 1984$ & $\cdots \cdots$ & $\cdots \cdots$ \\
\hline $\begin{array}{l}\text { Wet Botton Creek } \\
\text { near Childs } \\
\text { (09508300) }\end{array}$ & $6 / 67 \cdot 1987$ & $10 / 1968-1987$ & 15.7 & 15.0 \\
\hline $\begin{array}{l}\text { Verde River below } \\
\text { Tangle Creek above } \\
\text { Horseshoe Dam } \\
(09508500)\end{array}$ & $8 / 45 \cdot 1987$ & $10 / 1980-1987$ & 2567 & 815 \\
\hline $\begin{array}{l}\text { Verde River below } \\
\text { Bartlett Dan } \\
(09510000)\end{array}$ & $8 / 1888 \cdot 1987$ & $12 / 1950-1987$ & 2681 & 602 \\
\hline
\end{tabular}

1 Based on surface-water data through 1985 water year.
2 Based on surface-water data through 1986 water year.

Dissolved-solids concentrations in water are widely used in evaluating water quality. Excess dissolved solids are objectionable in drinking water because of possible physiological effects, unpalatable mineral tastes, and higher costs because of corrosion or the necessity for additional treatment (U.S. Environmental Protection Agency, 1976). OwenJoyce and Bell (1983) stated that large dissolved-solids and lead concentrations have been noted in parts of the Verde River system. The State of Arizona does not have a maximum allowable limit (MAL) (table 3 ) for dissolved solids in water that the State has designated as a surface-water resource (Melinda K. Longsworth, hydrologist, Arizona Department of Environmental Quality, written commun., 1989). The U.S. Environmental Protection Agency (1990) has established a secondary maximum contaminant level (SMCL) of $500 \mathrm{mg} / \mathrm{L}$ (milligrams per liter) for dissolved solids. A SMCL recommended for a constituent is considered nonenforceable by Federal guidelines under the Safe Drinking Water Act of 1986, whereas a maximum contaminant level (MCL) standard promulgated by the U.S. Environmental Protection Agency is considered enforceable.

Owen-Joyce and Bell (1983) indicated that mine drainages could be contributing large concentrations of sulfate and iron to the Verde River, especially near the mouth of Bitter Creek, which heads in the Black Hills northeast of Jerome (fig. 1). Sulfate concentrations in excess of $250 \mathrm{mg} / \mathrm{L}$ in domestic water supplies exceed SMCL's promulgated by the U.S. 
Table 3. - Maximum contaminant levels and maximum allowable limits for selected constituents in water. Verde River bas in, Arizona

Maximum contaminant levels, in milligrams per liter, total recoverable concentration unless noted. Dashes, no established maximm contaminant levels; $D$, dissolved concentration or activity]

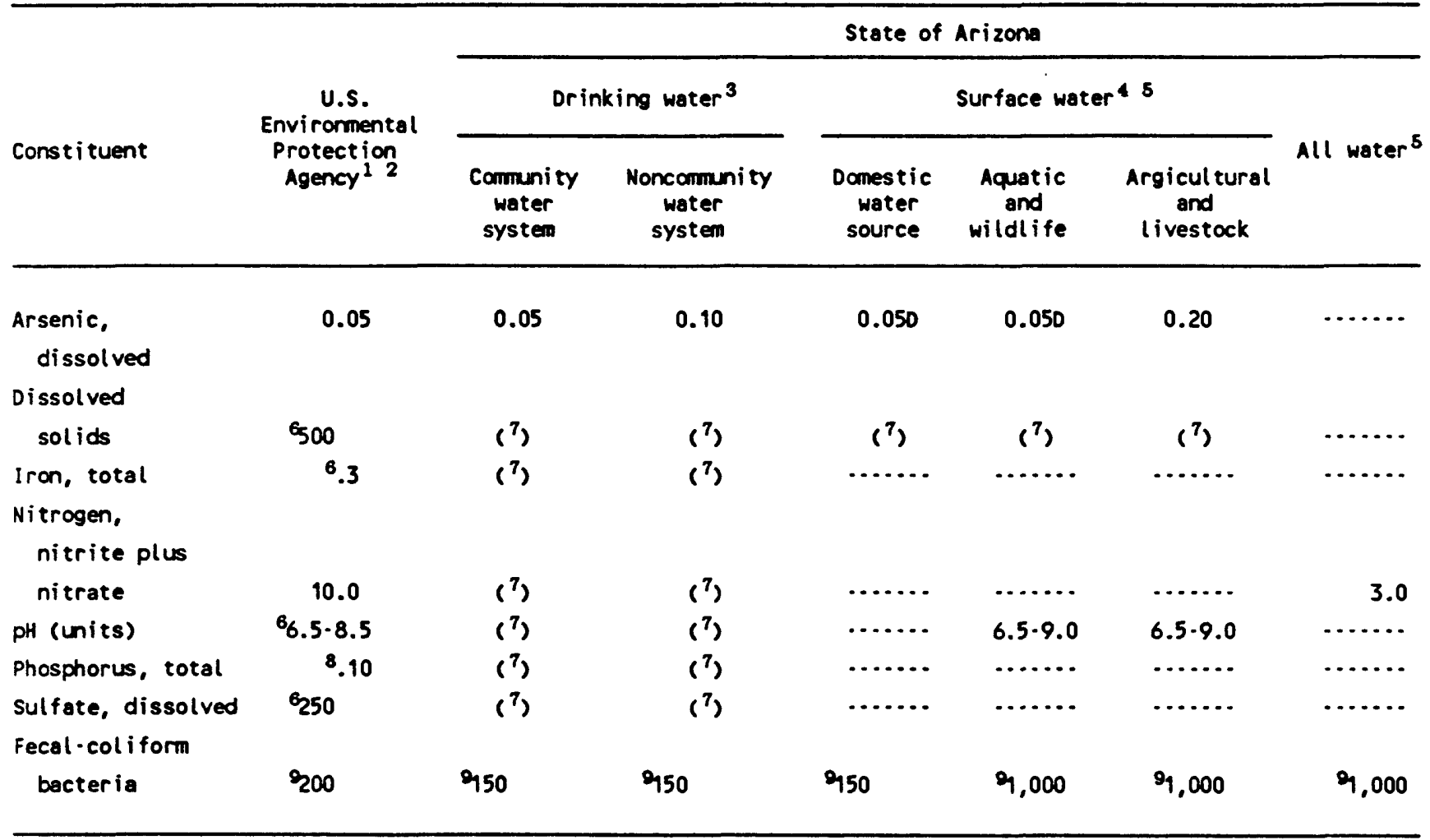

1U.S. Environmental Protection Agency, Office of Drinking Water, 1990, Drinking water regulations and health advisories; U.S. Emironmental Protection Agency Report, p. 1-10. Unless noted, all values in this column are primary drinking water maximum contaminant levels and apply to water in public water systems.

2U.S. Emirormental Protection Agency, 1986, Maximum contaminant levels (subpart B of part 141, National Interim Primary Drinking Water Regulations: U.S. Code of Federal Regulations, Title 40, Parts 100 to 149 , revised as of July 1, 1986, p. 524-528. Untess noted, all values in this colum are primary drinking water maximum contaminant levels and apply to water in public water systems.

3icClennan, J.J., 1984, Official compilation of administrative rules and regulations: Phoenix, Arizona, State of Arizona report, supplement 84-3, p. 68-84. Unless noted, all values in these colums are primary drinking water maximum allowable levels and apply to water in public water systems.

4MCClennan, J.J., 1986, Official compilation of administrative rules and regulations: Phoenix, Arizona, State of Arizona report, Advance Supplement $86-4$, p. 1-49. Unless noted, all values in this colum are maximum allowable limits and apply to surface water in the Verde River basin.

5tate of Arizona Atomic Energy Commission, 1977, Rules and regulations, title 12: Phoenix, Arizona, State of Arizona report, Supplement $77 \cdot 3$, p. 1-113. These standards (maximm permissible levels) apply to all waters released from external sources in unrestricted areas.

Galues are secondary maximum contaminant levels and apply to water in public water systems.

7To be monitored. No maximm contaminant level.

\&alues are maximum contaninant level and apply to water entering reservoirs.

'Colonies per 100 milliliters. 
Environmental Protection Agency (1990). Iron is an essential element in the metabolism of animals and plants. Iron, If present in water in excessive amounts, however, forms red oxyhydroxide precipitates that stain laundry and plumbing fixtures and therefore is an objectionable impurity in domestic and industrial water supplies (Hem, 1985). The State of Arizona does not have MAL's for these constituents (table 3 ), although water designated by the State as drinking water is monitored for these constituents. The U.S. Environmental Protection Agency (1990) has promulgated a SMCL of $0.3 \mathrm{mg} / \mathrm{L}$ for Iron.

Arsenic concentrations in some water-quality samples from wells in the study area were above the MAL of $50 \mu \mathrm{g} / \mathrm{L}$ (micrograms per liter) promulgated by the State of Arizona for community water systems. The State of Arizona has established a separate MAL of $20 \mu \mathrm{g} / \mathrm{L}$ for dissolved arsenic for water in Oak Creek, which the State has classified as part of its unique waters designation (Arizona Secretary of State, 1987). The Federal enforceable drinking-water standard for arsenic is $50 \mu \mathrm{g} / \mathrm{L}$. The dangers of ingestion of water containing large concentrations of arsenic have been well documented by a number of investigations (Hem, 1985). Owen-Joyce and Bell (1983) hypothesized that a major source of arsenic is the regional aquifer in the study area.

The measurement of $\mathrm{pH}$, the negative log of the hydrogen activity in water, was selected because of its importance in chemical interactions and blological processes of natural waters. It is a major influence on the degree of toxicity attained by many compounds (U.S. Environmental Protection Agency, 1976). A lowering of $\mathrm{pH}$ could Indicate the addition of an acidic contaminant discharged to the stream. The State of Arizona has a different minimum limit for $\mathrm{pH}$ than that stated in table 3 for waters the State has designated for agricultural use, which is 4.5 standard pH units. The State of Arizona has a maximum allowable change in the Verde River of 0.5 standard $\mathrm{pH}$ units from the previous year's median $\mathrm{pH}$ value caused by the activities of man for water used for the following purposes: aquatic and wildife, incidental human contact, and full body contact.

Concern for elevated concentrations of phosphorus in streams is based primarily on the role of phosphorus in promoting eutrophication in reservoirs (Smith and others, 1982). Possible contributing sources of phosphorus in streams include treated sewage effluents, return flows carrying agricultural and domestic fertilizers, and leaking septic-tank systems. Natural processes of plants and animals also contribute phosphorus to streams (Hem, 1985). Although the State of Arizona does not have a MAL for total phosphorus, the State does monitor total phosphates in the Verde River and tributaries to Bartlett Lake. The MAL's the State has established for total phosphates in these waters are $1.0 \mathrm{mg} / \mathrm{L}$ for a single sample, $0.30 \mathrm{mg} / \mathrm{L}$ at the $90 \mathrm{th}$ percentile for all samples, and $0.10 \mathrm{mg} / \mathrm{L}$ for the annual mean of samples. The 90th percentile is derived by ranking the data in order of magnitude and identifying the value that is larger than 90 percent of the data. The U.S. Environmental Protection Agency (1990) has promulgated the MCL of $0.10 \mathrm{mg} / \mathrm{L}$ for phosphorus in streams that flow into reservoirs.

The constituent total nitrite plus nitrate-nitrogen was selected because its presence in large concentrations could indicate point and nonpoint sources. Point sources could include municipal and industrial wastewaters, septic tanks, and feed-lot discharges. Nonpoint sources of 
nitrogen include agricultural fertilizer and animal wastes, lawn fertilizer, and leachate from waste-disposal dumps or sanitary landfills (U.S. Environmental Protection Agency, 1976). Nitrates become toxic under conditions that reduce them to nitrites. The reaction of nitrites with hemoglobin can be fatal to infants under 3 months of age (U.S. Environmental Protection Agency, 1976). The State of Arizona does not have MAL's established for total nitrite plus nitrate-nitrogen, although MAL's have been established for total nitrogen for the Verde River and tributaries to Bartlett Reservoir. These MAL's are $3.0 \mathrm{mg} / \mathrm{L}$ for a single sample maximum, $1.5 \mathrm{mg} / \mathrm{L}$ at the 90 th percentile for all samples, and $1.0 \mathrm{mg} / \mathrm{L}$ for the annual mean. Separate MAL's established by the State for Oak Creek (unique water designation) are $2.5 \mathrm{mg} / \mathrm{L}$ for a single sample maximum, $1.5 \mathrm{mg} / \mathrm{L}$ at the $90 \mathrm{th}$ percentile for all samples, and $1.0 \mathrm{mg} / \mathrm{L}$ for the annual mean. The U.S. Environmental Protection Agency (1990) has promulgated the MCL of $10 \mathrm{mg} / \mathrm{L}$ for total nitrite plus nitrate-nitrogen.

Fecal-coliform bacteria was added to the list of constituents because of a possible problem in the Oak Creek drainage basin. Near Sedona during low-flow periods of the intensive recreational-use summer months, large concentrations of fecal-coliform bacteria have exceeded the primary MCL of 200 colonies/100 ml (colonies per 100 milliliter) promulgated by the U.S. Environmental Protection Agency (1976) for drinking water. The U.S. Forest Service has established management practices targeted at reducing bacteria levels in the area (Julie E. Tupper, hydrologist, Coconino National Forest, oral commun., 1990). The State of Arizona has established MAL's for fecal-coliform bacteria concentrations for Oak Creek of 800 colonies per $100 \mathrm{ml}$ for a single sample and 150 colonies per $100 \mathrm{ml}$ for a geometric mean of a random set of at least 10 samples in any calendar month. Values in table 3 for the State of Arizona surface-water standards are those for the Verde River and are for a geometric mean of at least five samples. Not given in table 3 is a MAL established by the State of 200 colonies/100 m1 (geometric mean of five samples taken within a 30-day period) for full body contact use. A state MAL standard for fecal-coliform bacteria for the reach of the Verde River upstream from Bartlett Dam has not been established for domestic water sources. A MAL for the reach of the river downstream from Bartlett Dam for fecal-coliform bacteria of 1,000 colonies per $100 \mathrm{ml}$ (geometric mean of five samples taken within a 30-day period) has been established for domestic water supplies.

\section{SUMRARY STATISTICS}

Summary statistics for the data collected at the six water-quality data-collection sites for the eight constituents identified for trend analysis are given in table 4. Visual summaries of the distribution of the data for the eight water-quality constituents through the use of boxplots are shown in figure 3. A boxplot is constructed by ranking data from smallest to largest, and a box is drawn from the 25 th percentile to the 75 th percentile. The box length equals the interquartile range. A center line is drawn across the box at the median. "Whiskers" are then drawn from the quartiles to two adjacent values. The upper adjacent value is defined as the largest data point less than or equal to the upper quartile plus 1.5 times the interquartile range. The lower adjacent values are defined similarly. Values more extreme than the adjacent values and within a range of 1.5 to 3.0 times the interquartile range are called outside values and 
Table 4. - Summary statistics for water-quality dato used in time-trend analys is

\begin{tabular}{|c|c|c|c|c|c|c|c|c|}
\hline Station name and number & $\begin{array}{l}\text { Period } \\
\text { of record }\end{array}$ & $\begin{array}{l}\text { Number } \\
\text { of } \\
\text { samples }\end{array}$ & Meen & Medien & Minimm & Maximum & $\begin{array}{l}\text { Standard } \\
\text { deviation }\end{array}$ & $\begin{array}{l}\text { Standard } \\
\text { error of } \\
\text { the mean }\end{array}$ \\
\hline \multicolumn{9}{|c|}{ Dissolved solids, in milligrams per liter } \\
\hline $\begin{array}{l}\text { Verde River near } \\
\text { Clarkdale } 09504000\end{array}$ & $\begin{array}{l}3 / 76 \cdot 10 / 83 \\
10 / 86 \cdot 3 / 87\end{array}$ & 71 & 246 & 269 & 77.0 & 309 & 56.9 & 6.75 \\
\hline $\begin{array}{l}\text { Oak Creek at Red Rock } \\
\text { Crossing near Sedona } \\
09504440\end{array}$ & $\begin{array}{l}\text { 10/78-10/83, } \\
10 / 86 \cdot 3 / 87\end{array}$ & 33 & 152 & 167 & 58.0 & 189 & 34.9 & 6.07 \\
\hline $\begin{array}{l}\text { Verde River near Camp } \\
\text { Verde } 09506000\end{array}$ & $10 / 78-9 / 84$ & 69 & 403 & 421 & 93.0 & 618 & 129 & 15.6 \\
\hline $\begin{array}{l}\text { Wet Bottom Creek near } \\
\text { Childs } 09508300\end{array}$ & $8 / 68 \cdot 3 / 87$ & 127 & 163 & 167 & 50.0 & 367 & 70.9 & 6.29 \\
\hline $\begin{array}{l}\text { Verde River below } \\
\text { Tangle Creek above } \\
\text { Horseshoe Dam } \\
09508500\end{array}$ & $10 / 80-3 / 87$ & 49 & 328 & 345 & 113 & 428 & 74.1 & 10.6 \\
\hline $\begin{array}{l}\text { Verde River below } \\
\text { Bartlett Dam } 09510000\end{array}$ & $12 / 50 \cdot 3 / 87$ & 521 & 311 & 333 & 98.0 & 550 & 85.9 & 3.76 \\
\hline Do. & $12 / 50 \cdot 11 / 80$ & 487 & 313 & 338 & 98.0 & 550 & 87.2 & 3.95 \\
\hline Do. & $12 / 80 \cdot 3 / 87$ & 34 & 285 & 280 & 168 & 375 & 60.5 & 10.4 \\
\hline
\end{tabular}

Dissolved sulfate, in milligrams per liter

$[<$, less than analytical detection limit]

\begin{tabular}{|c|c|c|c|c|c|c|c|c|}
\hline $\begin{array}{l}\text { Verde River near } \\
\text { Clarkdale } 09504000\end{array}$ & $\begin{array}{l}3 / 76 \cdot 10 / 83 \\
10 / 86 \cdot 3 / 87\end{array}$ & 81 & 8.76 & 9.1 & $<1.0$ & 13.0 & 2.24 & 0.25 \\
\hline $\begin{array}{l}\text { Oak Creek at Red Rock } \\
\text { Crossing near Sedona } \\
09504440\end{array}$ & $\begin{array}{l}10 / 78-10 / 83 \\
10 / 86-3 / 87\end{array}$ & 40 & 3.98 & 3.6 & $<1.0$ & 10.0 & 2.47 & .39 \\
\hline $\begin{array}{l}\text { Verde River near Camp } \\
\text { Verde } 09506000\end{array}$ & $10 / 78-9 / 84$ & 70 & 95.4 & 90.0 & 7.0 & 210 & 50.6 & 6.04 \\
\hline $\begin{array}{l}\text { Wet Bottom Creek near } \\
\text { Childs } 09508300\end{array}$ & $8 / 68 \cdot 3 / 87$ & 139 & 8.62 & 8.4 & $<1.0$ & 28.0 & 3.78 & .32 \\
\hline $\begin{array}{l}\text { Verde River below } \\
\text { Tangle Creek above } \\
\text { Horseshoe Dam } 09508500\end{array}$ & $10 / 80 \cdot 3 / 87$ & 49 & 60.9 & 64.0 & 11.0 & 100 & 23.5 & 3.36 \\
\hline $\begin{array}{l}\text { Verde River below } \\
\text { Bartlett Dam } 09510000\end{array}$ & $12 / 50-3 / 87$ & 389 & 52.2 & 57.0 & 9.6 & 110 & 22.4 & 1.13 \\
\hline Do. & $12 / 50 \cdot 11 / 80$ & 355 & 52.6 & 58.0 & 9.6 & 110 & 22.6 & 1.20 \\
\hline Do. & $12 / 80-3 / 87$ & 34 & 48.1 & 45.0 & 13.0 & 80.0 & 19.7 & 3.38 \\
\hline
\end{tabular}


Table 4.-- Sumary statistics for water-quality data used in time-trend analysis - Cont inued

\begin{tabular}{|c|c|c|c|c|c|c|c|c|}
\hline Station name and number & $\begin{array}{l}\text { Period } \\
\text { of record }\end{array}$ & $\begin{array}{l}\text { Number } \\
\text { of } \\
\text { samples }\end{array}$ & Meen & Median & Minimu & Maximm & $\begin{array}{l}\text { Standard } \\
\text { deviation }\end{array}$ & $\begin{array}{l}\text { Standard } \\
\text { error of } \\
\text { the mean }\end{array}$ \\
\hline \multicolumn{9}{|c|}{ Dissolved arsenic, in micrograms per liter } \\
\hline $\begin{array}{l}\text { Verde River near } \\
\text { Clarkdale } 09504000\end{array}$ & $\begin{array}{l}3 / 76 \cdot 10 / 83 \\
10 / 86 \cdot 3 / 87\end{array}$ & 6 & 14.3 & 16 & 4 & 18 & $\cdots \cdots$ & $\cdots \cdots$ \\
\hline $\begin{array}{l}\text { Oak Creek at Red Rock } \\
\text { Crossing near Sedona } \\
09504440\end{array}$ & $\begin{array}{l}10 / 78 \cdot 10 / 83 \\
10 / 86 \cdot 3 / 87\end{array}$ & 6 & 4.0 & 4 & 2 & 5 & $\cdots \cdots$ & $\cdots \cdots$ \\
\hline $\begin{array}{l}\text { Verde River near Camp } \\
\text { Verde } 09506000\end{array}$ & $10 / 78-9 / 84$ & 0 & $\cdots$ & $\cdots$ & $\cdots \cdots$ & $\cdots \cdots$ & $\cdots$ & $\cdots \cdots$ \\
\hline $\begin{array}{l}\text { Wet Botton Creek near } \\
\text { Childs } 09508300\end{array}$ & $8 / 68 \cdot 3 / 87$ & 21 & 9.29 & 8 & 1 & 22 & 6.55 & 1.43 \\
\hline $\begin{array}{l}\text { Verde River below } \\
\text { Tangle Creek above } \\
\text { Horseshoe Dam } 09508500\end{array}$ & $10 / 80 \cdot 3 / 87$ & 31 & 5.6 & 17 & 2 & 26 & 5.46 & .98 \\
\hline $\begin{array}{l}\text { Verde River below } \\
\text { Bartlett Dam } 09510000\end{array}$ & $1 / 74-3 / 87$ & 49 & 11.6 & 12 & 5 & 18 & 3.24 & .46 \\
\hline Do. & $1 / 74 \cdot 11 / 80$ & 20 & 12.0 & 13 & 5 & 18 & 4.16 & .93 \\
\hline Do. & $12 / 80 \cdot 3 / 87$ & 29 & 11.3 & 12 & 7 & 17 & 2.45 & .46 \\
\hline
\end{tabular}

Total phosphorus, in milligrams per liter $[<$, less than analytical detection limit]

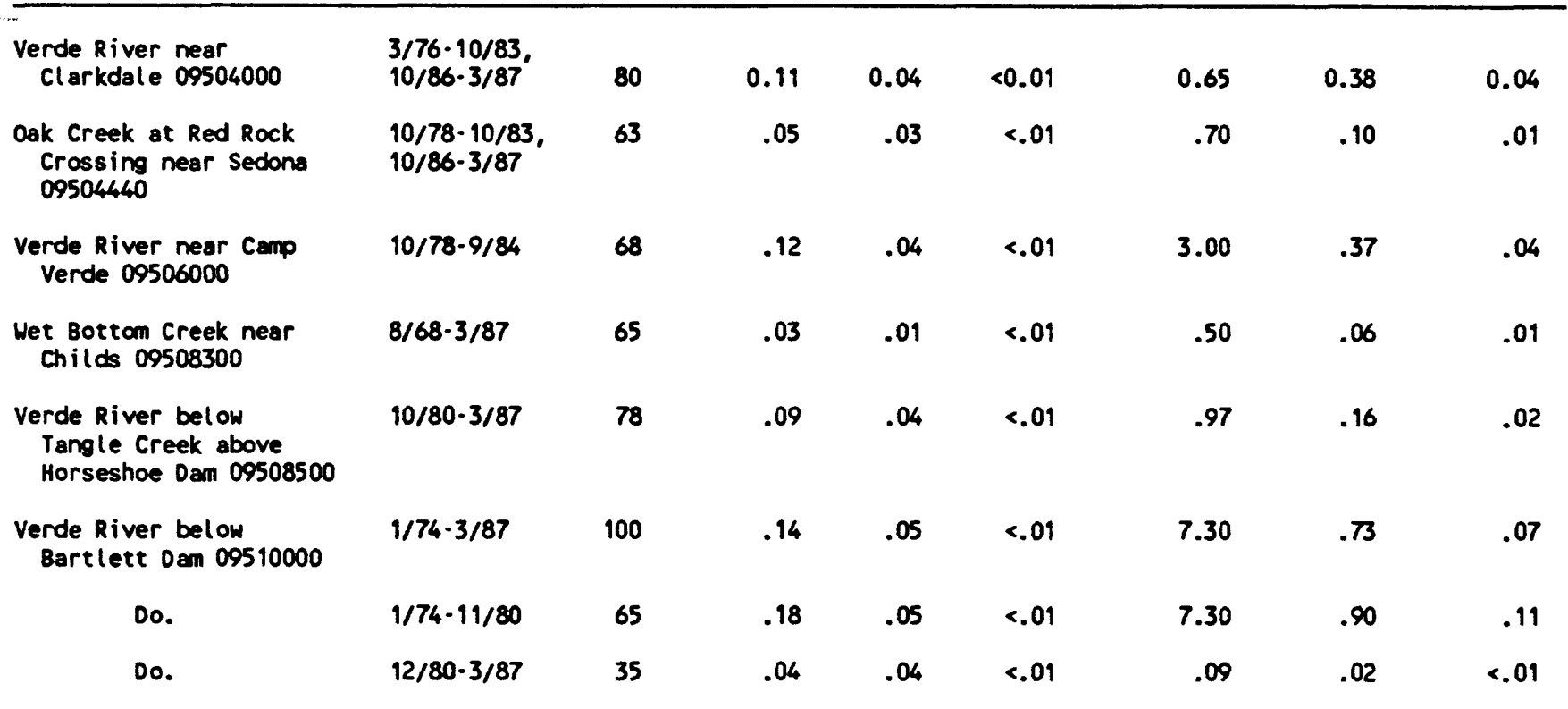


Table 4. - - Sumary statistics for water-qual ity data used in time-trend analysis-- Cont inued

\begin{tabular}{|c|c|c|c|c|c|c|c|c|}
\hline Stat ion name and number & $\begin{array}{l}\text { Period } \\
\text { of record }\end{array}$ & $\begin{array}{l}\text { Number } \\
\text { of } \\
\text { samples }\end{array}$ & Mean & Medien & Minimum & Maximn & $\begin{array}{l}\text { Standard } \\
\text { deviation }\end{array}$ & $\begin{array}{l}\text { Standard } \\
\text { error of } \\
\text { the mean }\end{array}$ \\
\hline \multicolumn{9}{|c|}{ PH, in standard units } \\
\hline $\begin{array}{l}\text { Verde River near } \\
\text { Clarkdale } 09504000\end{array}$ & $\begin{array}{l}3 / 76-10 / 83 \\
10 / 86-3 / 87\end{array}$ & 80 & $\cdots \cdots$ & 8.20 & 6.90 & 8.60 & $\cdots \cdots$ & $\cdots \cdots$ \\
\hline $\begin{array}{l}\text { Oak Creek at Red Rock } \\
\text { Crossing near Sedona } \\
09504440\end{array}$ & $\begin{array}{l}10 / 78-10 / 83 \\
10 / 86-3 / 87\end{array}$ & 63 & $\cdots \cdots$ & 8.30 & 6.90 & 8.80 & $\cdots$ & $\cdots$ \\
\hline $\begin{array}{l}\text { Verde River near Camp } \\
\text { Verde } 09506000\end{array}$ & $10 / 78 \cdot 9 / 84$ & 71 & $\cdots \cdots$ & 8.30 & 6.40 & 8.60 & $\cdots$ & $\cdots \cdots$ \\
\hline $\begin{array}{l}\text { Wet Botton Creek near } \\
\text { Childs } 09508300\end{array}$ & $8 / 68 \cdot 3 / 87$ & 91 & $\cdots \cdot$. & 7.90 & 7.00 & 9.40 & $\cdots \cdots$ & $\cdots \cdots$ \\
\hline $\begin{array}{l}\text { Verde River below } \\
\text { Tangle Creek above } \\
\text { Horseshoe Dam } 09508500\end{array}$ & $10 / 80-3 / 87$ & 79 & $\cdots \cdots$ & 8.50 & 6.50 & 9.00 & $\cdots \cdots$ & $\cdots$ \\
\hline $\begin{array}{l}\text { Verde River below } \\
\text { Bartlett Dam } 09510000\end{array}$ & $12 / 50 \cdot 3 / 87$ & 544 & $\cdots \cdots$ & 8.00 & 6.80 & 8.90 & $\cdots \cdots$ & $\cdots \cdots$ \\
\hline Do. & $12 / 50 \cdot 11 / 80$ & 508 & $\cdots \cdots$ & 8.00 & 6.80 & 8.90 & $\cdots \cdots$ & $\cdots \cdot$ \\
\hline Do. & $12 / 80-3 / 87$ & 36 & ...... & 8.30 & 7.30 & 8.70 & - . . & ..... \\
\hline
\end{tabular}

Total nitrite plus nitrate-nitrogen, in milligrams per liter

\begin{tabular}{|c|c|c|c|c|c|c|c|c|}
\hline $\begin{array}{l}\text { Verde River near } \\
\text { Clarkdale } 09504000\end{array}$ & $\begin{array}{l}3 / 76-10 / 83 \\
10 / 86-3 / 87\end{array}$ & 80 & 0.14 & 0.10 & 0.01 & 0.59 & 0.12 & 0.01 \\
\hline $\begin{array}{l}\text { Oak Creek at Red Rock } \\
\text { Crossing near Sedona } \\
09504440\end{array}$ & $\begin{array}{l}10 / 78 \cdot 10 / 83 \\
10 / 86 \cdot 3 / 87\end{array}$ & 63 & .03 & .05 & .01 & .14 & .03 & .00 \\
\hline $\begin{array}{l}\text { Verde River near Camp } \\
\text { Verde } 09506000\end{array}$ & $10 / 78 \cdot 9 / 84$ & 69 & .08 & .05 & .01 & 1.30 & .17 & .02 \\
\hline $\begin{array}{l}\text { Wet Bottom Creek near } \\
\text { Childs } 09508300\end{array}$ & $8 / 68-3 / 87$ & 47 & 0.04 & 0.03 & 0.01 & 0.39 & 0.07 & 0.01 \\
\hline $\begin{array}{l}\text { Verde River below } \\
\text { Tangle Creek above } \\
\text { Horseshoe Dam } 09508500\end{array}$ & $10 / 80 \cdot 3 / 87$ & 78 & .04 & .05 & .01 & .30 & .05 & .01 \\
\hline $\begin{array}{l}\text { Verde River below } \\
\text { Bartlett Dam } 09510000\end{array}$ & $12 / 50 \cdot 3 / 87$ & 88 & .11 & .08 & .01 & .41 & .08 & .01 \\
\hline Do. & $12 / 50-11 / 80$ & 63 & .12 & .10 & .01 & .41 & .09 & .01 \\
\hline Do. & $12 / 80 \cdot 3 / 87$ & 25 & .08 & .05 & .04 & .27 & .06 & .01 \\
\hline
\end{tabular}


Table 4.- - Summary statistics for water-quality data used in time-trend analys is.-Cont inued

\begin{tabular}{|c|c|c|c|c|c|c|c|c|}
\hline Station name and number & $\begin{array}{l}\text { Period } \\
\text { of record }\end{array}$ & $\begin{array}{l}\text { Number } \\
\text { of } \\
\text { samples }\end{array}$ & Mean & Median & Minimum & Maximum & $\begin{array}{l}\text { Standard } \\
\text { deviation }\end{array}$ & $\begin{array}{l}\text { Standard } \\
\text { error of } \\
\text { the mean }\end{array}$ \\
\hline
\end{tabular}

Dissolved iron, in micrograms per liter

$[<$, less than analytical detection limit]

\begin{tabular}{|c|c|c|c|c|c|c|c|c|}
\hline $\begin{array}{l}\text { Verde River near } \\
\text { Clarkdale } 09504000\end{array}$ & $\begin{array}{l}3 / 76-10 / 83 \\
10 / 86-3 / 87\end{array}$ & 59 & 34.2 & 19.0 & $<3.0$ & 320 & 64.6 & 8.41 \\
\hline $\begin{array}{l}\text { Oak Creek at Red Rock } \\
\text { Crossing near Sedona } \\
09504440\end{array}$ & $\begin{array}{l}10 / 78 \cdot 10 / 83 \\
10 / 86 \cdot 3 / 87\end{array}$ & 41 & 44.0 & 40.0 & 5.0 & 220 & 38.5 & 6.01 \\
\hline $\begin{array}{l}\text { Verde River near Camp } \\
\text { Verde } 09506000\end{array}$ & $10 / 78 \cdot 9 / 84$ & 44 & 26.7 & 9.50 & $<3.0$ & 350 & 57.7 & 8.70 \\
\hline $\begin{array}{l}\text { Wet Bottom Creek near } \\
\text { Childs } 09508300\end{array}$ & $8 / 68 \cdot 3 / 87$ & 57 & 66.4 & 40.0 & $<10.0$ & 780 & 110 & 14.6 \\
\hline $\begin{array}{l}\text { Verde River below } \\
\text { Tangle Creek above } \\
\text { Horseshoe Dam } 09508500\end{array}$ & $10 / 80 \cdot 3 / 87$ & 49 & 12.8 & 5.00 & $<3.0$ & 140 & 22.9 & 3.27 \\
\hline $\begin{array}{l}\text { Verde River below } \\
\text { Bartlett Dam } 09510000\end{array}$ & $12 / 50-3 / 87$ & 90 & 27.8 & 12.0 & $<3.0$ & 440 & 56.2 & 5.92 \\
\hline Do. & $12 / 50 \cdot 11 / 80$ & 61 & 36.2 & 20.0 & $<10.0$ & 440 & 66.2 & 8.48 \\
\hline Do. & $12 / 80-3 / 87$ & 29 & 10.2 & 6.0 & $<3.0$ & 70.0 & 13.4 & 2.48 \\
\hline \multicolumn{9}{|c|}{$\begin{array}{l}\text { Fecal coliform bacteria, in colonies per } 100 \text { milliliters } \\
{[<\text {, less than analytical detection limit] }}\end{array}$} \\
\hline $\begin{array}{l}\text { Verde River near } \\
\text { Clarkdale } 09504000\end{array}$ & $\begin{array}{l}3 / 76 \cdot 10 / 83 \\
10 / 86 \cdot 3 / 87\end{array}$ & 73 & 38.3 & 10 & $<1$ & 900 & 117 & 13.6 \\
\hline $\begin{array}{l}\text { Oak Creek at Red Rock } \\
\text { Crossing near Sedona } \\
09504440\end{array}$ & $\begin{array}{l}10 / 78 \cdot 10 / 83 \\
10 / 86 \cdot 3 / 87\end{array}$ & 61 & 71.6 & 12 & $<1$ & 1,100 & 197 & 25.2 \\
\hline $\begin{array}{l}\text { Verde River near Camp } \\
\text { Verde } 09506000\end{array}$ & $10 / 78 \cdot 9 / 84$ & 60 & 174 & 12 & $<1$ & 5,000 & 716 & 92.4 \\
\hline $\begin{array}{l}\text { Wet Bottom Creek near } \\
\text { Childs } 09508300\end{array}$ & $8 / 68-3 / 87$ & 57 & 65.1 & 7 & $<1$ & 680 & 148 & 19.6 \\
\hline $\begin{array}{l}\text { Verde River below } \\
\text { Tangle Creek above } \\
\text { Horseshoe Dam } 09508500\end{array}$ & $10 / 80 \cdot 3 / 87$ & 69 & 108 & 9 & $<1$ & 2,100 & 330 & 39.8 \\
\hline $\begin{array}{l}\text { Verde River below } \\
\text { Bartlett Dan } 09510000\end{array}$ & $1 / 76 \cdot 3 / 87$ & 79 & 10.0 & 2 & $<1$ & 130 & 23.1 & 2.60 \\
\hline Do. & $1 / 76 \cdot 11 / 80$ & 40 & 10.3 & 1 & $<1$ & 130 & 26.7 & 4.22 \\
\hline Do. & $12 / 80 \cdot 3 / 87$ & 39 & 9.72 & 4 & $<1$ & 110 & 19.1 & 3.06 \\
\hline
\end{tabular}



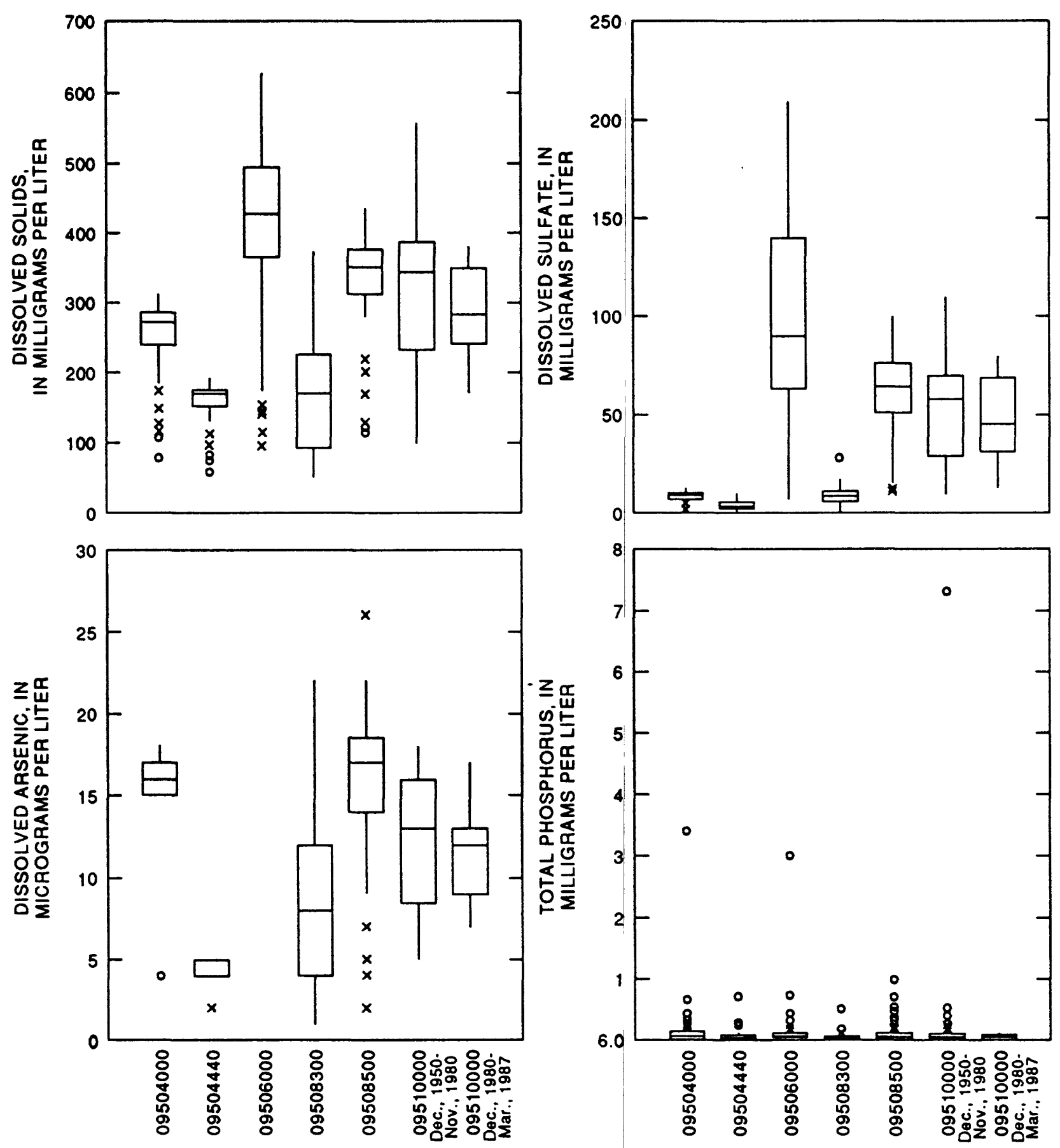

Figure 3.-Boxplots of constituent concentrations. 

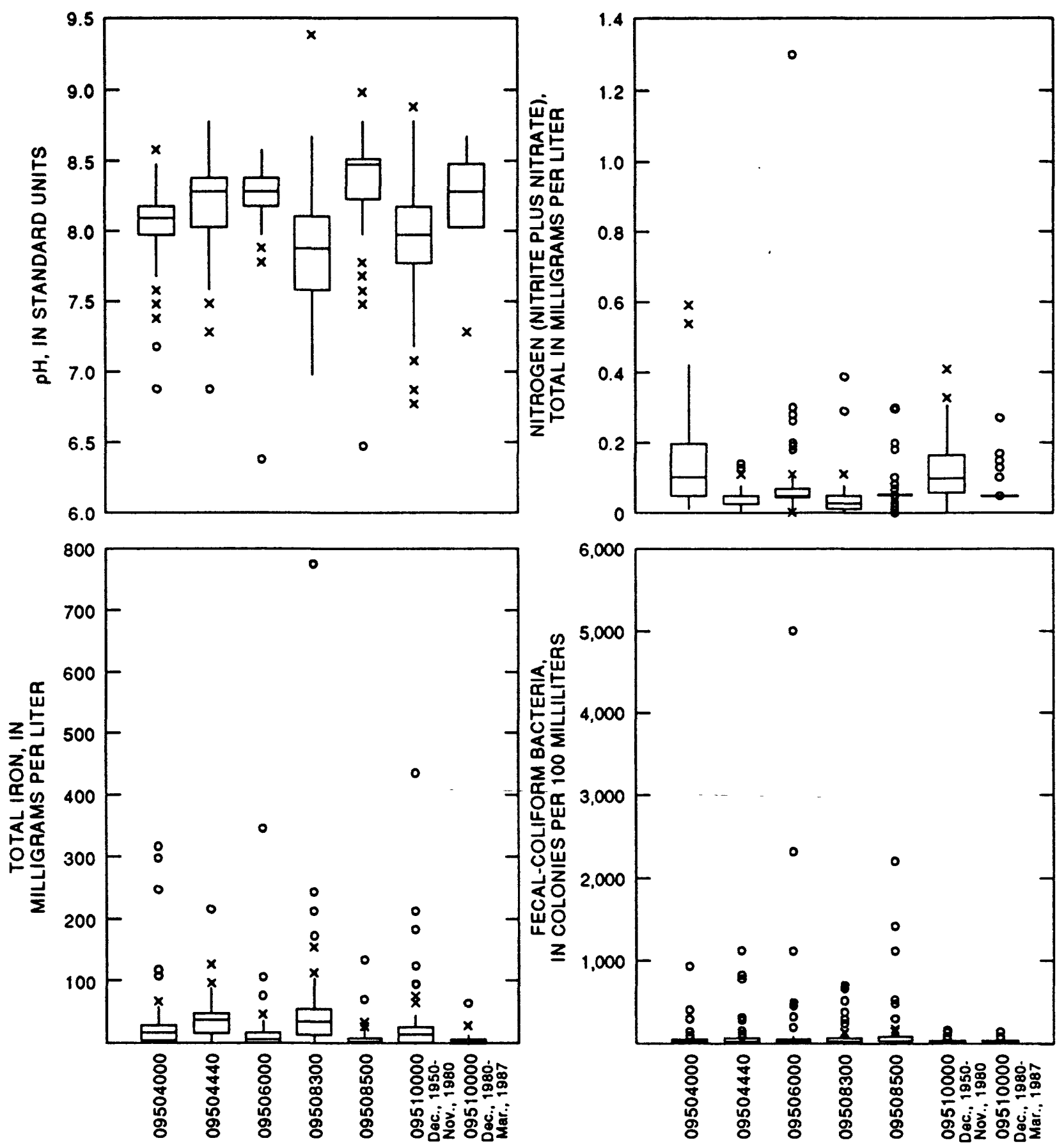

\section{EXPLANATION}

- extreme value

$\times$ outSIDE VALUe

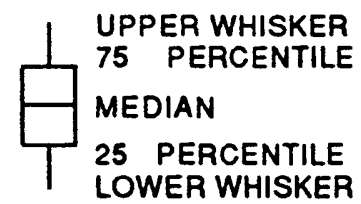

Figure 3.-Boxplots of constituent concentrations-Continued. 
are plotted with an asterisk. Data values greater than or less than three times the interquartile range are called extreme values and are plotted with a circle. Mean values for the constituents were less than the recommended maximum contaminant levels by the Environmental Protection Agency except for total phosphorus concentrations at the Verde River near Camp Verde site and below Bartlett Dam site for 1974-80. Mean concentrations for the eight constituents indicate that water from the Verde River system is of good Inorganic quality.

Water-quality data for concentrations of total phosphorus, total nitrite plus nitrate-nitrogen, and dissolved iron contain values reported as "less than the analytical detection limit." Data for concentrations of dissolved iron are reported with multiple detection limits. Helsel and Cohn (1988) investigated the reliability of eight different methods of computing summary statistics using data that contained "less than" values. This study used the logarithmic-probability regression method developed by Helsel and Cohn (1988) to compute summary statistics for the three constituents that contained "less than" data. Summary statistics for the remaining five water-quality constituents were determined using statistical software packages available on the minicomputer in the Arizona District.

Mean dissolved-solids concentrations varied considerably between sites. The mean concentration of $246 \mathrm{mg} / \mathrm{L}$ at Verde River near Clarkdale increased to $403 \mathrm{mg} / \mathrm{L}$ at the next downstream site, Verde River near Camp Verde. The major tributary between these two sites is Oak Creek, which had a mean concentration of $152 \mathrm{mg} / \mathrm{L}$. This increase indicates that a source of large concentrations of dissolved solids entered the Verde River between the two Verde River sites that was not attributable to Oak Creek. Dissolved-solids concentrations decreased at the other three study sites (fig. 3). This decrease could be caused from dilution by water that contains smaller dissolved-solids concentrations entering the system from tributaries.

The Verde River near Camp Verde site had the largest mean dissolved-sulfate concentration, $95.4 \mathrm{mg} / \mathrm{L}$, of all six sites in this study. The upstream site, Verde River near Clarkdale, had a mean dissolved-sulfate concentration of $8.76 \mathrm{mg} / \mathrm{L}$. The mean concentration at the Oak Creek site was less than $4 \mathrm{mg} / \mathrm{L}$, indicating that water containing large concentrations of sulfate entered the Verde River between the clarkdale and Camp Verde sampling sites. The $25 \mathrm{th}$ percentile of dissolved-sulfate data at Verde River near Camp Verde generally was larger than median values of the rest of the study sites (fig. 3).

The number of samples collected for arsenic determinations at each of the six sites range from 0 at Verde River below Camp Verde to 49 at Verde River below Bartlett Dam. Only six arsenic samples each were collected at Oak Creek and Verde River near Clarkdale sites. The maximum arsenic concentration measured at each site was less than the MCL of $0.05 \mathrm{mg} / \mathrm{L}$ or $50 \mu \mathrm{g} / \mathrm{L}$ recommended by the Environmental Protection Agency and the State of Arizona for certain water uses, although interquartile ranges varied considerably at the sites ( $f 1 g$. 3). However, because of the large concentrations of arsenic found by Owen-Joyce and Bell (1983) and the small amount of arsenic data available from streamflow sampling, additional arsenic data are needed. 
Mean total-phosphorus concentrations ranged from $0.03 \mathrm{mg} / \mathrm{L}$ at the Wet Bottom Creek site to $0.18 \mathrm{mg} / \mathrm{L}$ at the Verde River below Bartlett Dam site. The State of Arizona's MAL for total phosphate for water in the Verde River is $0.10 \mathrm{mg} / \mathrm{L}$ for the annual mean, $0.30 \mathrm{mg} / \mathrm{L}$ for the $90 \mathrm{th}$ percentile, and $1.0 \mathrm{mg} / \mathrm{L}$ for a single sample. The U.S. Environmental Protection Agency promulgates the MAL of $0.10 \mathrm{mg} / \mathrm{L}$ for total phosphorus. The mean totalphosphorus concentration at Verde River above Horseshoe Dam is $0.09 \mathrm{mg} / \mathrm{L}$. The mean concentration of $0.18 \mathrm{mg} / \mathrm{L}$ at Verde River below Bartlett Dam for 1974 through November 1980 was more than four times greater than that for December 1980 through March 1987. The change in sampling location at Verde River below Bartlett Dam could be the reason for the difference between the two time periods. The mean concentrations of $0.12 \mathrm{mg} / \mathrm{L}$ at Verde $R$ iver near Camp Verde and $0.11 \mathrm{mg} / \mathrm{L}$ at Verde River near Clarkdale were slightly less than the mean value at Verde River above Horseshoe Dam. Minimum concentration values of less than $0.01 \mathrm{mg} / \mathrm{L}$ were reported for all study sites. The logarithmic-probability regression method was used to determine summary statistics for total-phosphorus concentrations at the study sites because several total-phosphorus values were recorded as "less than" values (Helsel and Cohn, 1988).

Median $\mathrm{pH}$ levels for all six sites were within the recommended Environmental Protection Agency (6.5 to 8.5) and State (6.5 to 9.0) ranges. The minimum $\mathrm{pH}$ value of 6.40 was recorded at the Verde River near Camp Verde site, and the maximum of 9.40 was recorded at the Wet Bottom Creek near Childs site. The interquartile ranges of $\mathrm{pH}$ data at the study sites do not show changes in $\mathrm{pH}$ levels that would violate the State of Arizona standard stating that activities of man are not allowed to cause a change in $\mathrm{pH}$ levels of greater than $0.5 \mathrm{pH}$ standard units (fig. 3 ).

The two tributaries to the Verde River had the smallest mean values of total nitrite plus nitrate-nitrogen concentrations, $0.03 \mathrm{mg} / \mathrm{L}$ at Oak Creek at Red Rock Crossing near Sedona and $0.04 \mathrm{mg} / \mathrm{L}$ at Wet Bottom Creek near Childs. The largest mean concentrations were recorded at Verde River near Clarkdale, $0.14 \mathrm{mg} / \mathrm{L}$, and at Verde River below Bartlett Dam, $0.12 \mathrm{mg} / \mathrm{L}$, for 1950 to November 1980. These two sites had the widest interquartile range of the study sites (fig. 3). Summary statistics for the total nitrite plus nitrate-nitrogen constituent were calculated using the logarithmicprobability regression method on data that included "less than" values. This was a result of an analytical change for samples collected after the 1981 water year.

The maximum dissolved-iron concentration of $780 \mu \mathrm{g} / \mathrm{L}(0.78 \mathrm{mg} / \mathrm{L})$ for an individual sample from the six sites was recorded at Wet Bottom Creek near Childs. Four of the sites had individual sample values that were greater than the SMCL for drinking water of $0.3 \mathrm{mg} / \mathrm{L}$ for total iron; however, the mean dissolved-iron concentration at each of the six sites was less than the SMCL for drinking water (U.S. Environmental Protection Agency, 1990). Dissolved-iron concentrations of $10 \mu \mathrm{g} / \mathrm{L}$ or less were entered in the data base as "less than" values, $<10 \mu \mathrm{g} / \mathrm{L},<3.0 \mu \mathrm{g} / \mathrm{L}$, and as natural numbers. Summary statistics for dissolved iron were computed using the logarithmic-probability regression method.

Fecal-coliform bacteria concentrations generally were well within the MAL's specified by the State of Arizona for surface water (table 3 ). 
The State standard of 800 colonies per $100 \mathrm{ml}$ for a single sample from Oak Creek was rarely exceeded (fig. 3). The maximum fecal-coliform bacteria concentration of 5,000 colonies per $100 \mathrm{ml}$ was recorded at Verde River below Camp Verde. The concentrations were smallest at the Verde River below Bartlett Dam site. Twenty-seven samples at sites above Bartlett Dam exceeded the criteria of 200 colonies/100 ml for full body contact. The U.S. Geological Survey has a minimum reporting value for fecal-coliform bacteria concentrations of less than 1 colony/100 mI even though zero colonies/100 ml could have been found in the water samples.

\section{METHODS}

The two methods used in this study to analyze data for temporal trends in water-quality constituents are the ordinary least-squares (OLS) regression analysis and the seasonal Kendall tau test. The ols regression analysis is a parametric test and requires a data set of regression residuals that is normally distributed. The seasonal Kendall tau test is applied to raw concentration data and to discharge-adjusted concentration (DAC) data and does not require data to be normally distributed.

\section{Ordinary Least-Squares Regression Analysis}

The ordinary least-squares regression analysis is a common test for temporal trend that is based on linear regression of the water-quality constituent in question against time. Most water-quality data in a mathematically untransformed state when regressed against time do not have residuals from the regression that satisfy the assumptions of normality and homogeneity of variances needed for regression analysis. These assumptions are not met because the seasonal variability of the data is likely to be distributed nonuniformly. A method to remove some of the variability is by the use of an exogenous variable; in the case of water-quality constituent concentrations, the exogenous variable generally is instantaneous discharge. The removal of variability increases the power of the subsequent trend test. The OLS regression analysis with an exogenous variable is considered to have more power than the stagewise regression analysis, which is known also as residual analysis (Alley, 1987, p. 133). In OLS regression analysis, the $p$ value of the $t$-statistic on the coefficient $B_{2}$ from the following equation is evaluated for trend.

where

$$
f\left(c_{i}\right)=B_{0}+B_{1} f\left(Q_{i}\right)+B_{2} T+E
$$

$$
\begin{aligned}
c_{i} & =\text { instantaneous value of the water-quality variable, } \\
Q_{i} & =\text { instantaneous water discharge, } \\
T & =\text { date of sample (decimal time) } \\
B_{0}, B_{1}, B_{2} & =\text { regression parameters, and } \\
E & =\text { sample residual in regression. }
\end{aligned}
$$


The instantaneous-discharge value, $Q_{i}$, can be transformed mathematically by a number of methods in order tó produce a better model. This study used the following transformation functions of $f\left(Q_{i}\right)$.

Transformation

$$
\begin{aligned}
& f\left(Q_{i}\right)=Q_{i} \\
& f\left(Q_{i}\right)=\log 10\left(Q_{i}\right) \\
& f\left(Q_{i}\right)=1 / Q_{i} \\
& f\left(Q_{i}\right)=1 /\left(1+B Q_{i}\right)
\end{aligned}
$$

Type

Linear

Logarithmic

\section{Inverse}

Hyperbolic

( $B$ of the hyperbolic transformation is equal to $10^{\left[(-2.5)\left(\log 10\left(Q_{i}\right)\right)+X\right]}$ where $X$ varies from $10^{0.5}$

to $10^{3.5}$ and is increased by $10^{0.5}$ amounts.)

The hyperbolic transformation was used by Buell and Grams (1985) in their investigation of temporal trends in selected water-quality constituents for streams in Georgia. The constituent concentrations $\left(c_{i}\right)$ were used in either their raw format $f\left(c_{i}\right)=c_{j}$ or as a logarithmic base 10 transformed value $f\left(c_{i}\right)=\log 10\left(c_{i}\right)$. Using these transformations, several regression equations were computed. The equation with the best residual plot showing a normal distribution and with a coefficient of determination $\left(R^{2}\right)$ greater than 0.10 was selected to define the relation between discharge and the concentration of the constituent in question. This relation was used to provide a conditional expected value of concentration for every discharge value.

The $B_{2}$ coefficient on time (date of sample collection) was analyzed to determine if a trend exists by using a test for slope for an equation with normally distributed residuals that calculates a $p$ value for the t-statistic of $B_{2}$ (Iman and Conover, 1983). The $p$ value is the probability of rejecting the null hypothesis $\left(B_{2}-0\right)$. Calculation of the $p$ value allows the selection of a significance level according to individual preference. This report considers a p value of 0.0500 or less to be statistically significant and a rejection of the null hypothesis. A $p$ value of greater than 0.0500 would indicate that the null hypothesis was not rejected and that no trend exists in the water-quality constituent. Three problems exist with the ordinary least-squares regression analysis that lower the power of the test. The analysis is (1) affected by outlier values, (2) incapable of handling values reported as "less than," and (3) possibly affected by serial correlation in the regression residuals.

\section{Seasonal Kenda11 Tau Test}

The seasonal Kendall tau test is a distribution-free test that is not affected by the problems that affect the OLS regression analysis with the exception of serlal correlation. The major advantage of distributionfree tests is that the underlying probability distribution of the random variable is immaterial (Smith and others, 1982). The seasonal Kendall tau 
test used in this study was adapted from the method presented by Kendall (1975) and was applied to raw concentration data and discharge-adjusted concentration data. Discharge-adjusted concentration data are defined as the actual concentration minus the estimated conditional expected concentration.

The seasonal Kendall tau test on DAC data is accomplished in two steps. In the first step, a regression of the water-quality variable in question against instantaneous discharge is done to remove the variance associated with water discharge. The equation used for the regression is

$$
f\left(c_{i}\right)=B_{0}+B_{1} Q_{i}+e^{\prime}
$$

The variables used in equation 2 were defined in equation 1 with the exception of $e^{\prime}$, which is the model residual (error) resulting from equation 2. Similar transformations of data used for equation 1 were used in equation 2. Equation 2 was checked for normality of residuals. If residuals were normally distributed and the $R^{2}$ for equation 2 was greater than 0.10 , the residuals were renamed discharge-adjusted concentrations and the seasonal Kendall tau test was applied. In cases where the regression relations were poor ( $p>0.10)$, the estimated conditional expected concentration was defined as the mean concentration of the data set of the water-quality variable in question. The discharge-adjusted concentration for these cases was defined as the actual concentration minus the mean concentration of the data set. In the second step of the method, which is the application of the seasonal Kendall tau test, all possible pairs of data values are compared. If the later value (in time) is greater, a plus is scored; if the later value is smaller, a minus is scored; if the values are equal (tied), a zero is scored. The null hypothesis of no significant trend is accepted if the number of pluses is about the same as the number of minuses. If there are many more pluses than minuses, an increasing trend is likely, and, conversely, if there is a dominance of minuses, a downtrend is reported (Smith and others, 1982). In the seasonal Kendall tau test, only data pairs that occur during the same month of the year are included in the analysis. This reduced the problem of seasonality that normally occurs in water-quality data. If more than one sample value is collected during the same month of the same year, the first value collected is used in the analysis. A complete discussion of the seasonal Kendall tau test is given in appendix $B$ of the report by Smith and others (1982), and the derivation of the test is given by Hirsch and others (1981).

The seasonal Kendall tau slope estimator, which is an extension of the seasonal Kendall tau test, estimates the magnitude of the trend of the water-quality constituent. The estimator is defined by Smith and others (1982, p. 6) as the median of the differences (expressed as slopes) of the ordered pairs of data values that are compared in the seasonal Kendall tau test. The difference of each pair of data points was divided by the number of years separating them and was recorded in place of a minus or plus. The median value of these differences was accepted as the change per year of the water-quality constituent.

The seasonal Kendall tau test was applied to raw concentration data and to discharge-adjusted concentration data for the eight selected constituents at the six data-collection sites. The results of the analyses are given in table 5. The $p$ value, which is the probability of rejecting the null hypothesis of no trend in the water-quality constituent, was 
calculated for the seasonal Kendall tau test on both raw data and DAC data (table 5). The significance of the $p$ value is the same as discussed earlier. The magnitude of the trend of the constituent in question is reported as a constant rate of change per year for computations that did not use a logarithmic transformation of data. When a logarithmic transformation of data is used, the change measured in the raw (retransformed) data is not constant per year but is exponential with time because the change in $10 \mathrm{~g}$ units is linear over time (E.J. Gilroy, mathematician, U.S. Geological Survey, written commun., 1989). Hence, two values were entered in table 5 for the trend measured by the seasonal Kendall tau test on DAC data where logarlthmic transformation of the water-quality constituent data was made. The first value is the amount of change for 1 year, and the second value is the amount of change for the period of data collection of the constituent. The magnitude of the trend of the constituent is not calculated where more than a few "less than" values occur in the data set.

\section{TREND ANALYSIS}

Trend analysis of water-quality data for the eight constituents at the six data-collection sites was done using the ordinary least-squares regression analysis and the seasonal Kendall tau test. The constituents are dissolved solids, dissolved sulfate, dissolved arsenic, total phosphorus, $\mathrm{pH}$, total nitrite plus nitrate-nitrogen, dissolved iron, and fecal-coliform bacteria. Graphs were prepared showing raw concentration data; date of the sample; and trends, if any, that were detected by using the ordinary leastsquares regression analysis. Graphs also were prepared showing dischargeadjusted concentration data; date of sample; and trends, if any, that were detected by using the seasonal Kendall tau test.

\section{Dissolved Solids}

Trend analysis of water-quality data showed increasing trends of dissolved-solids concentrations at one site in the study area, Verde River at Camp Verde, and decreasing trends at the sites downstream. The increase in dissolved-solids concentrations was statistically significant with $p$ values of less than 0.0500 from both the OLS regression analysis ( $f i g$. 4) and the seasonal Kendall tau test on DAC data (fig. 5). The seasonal Kendall tau test on DAC data (using a logarithmic data transformation) calculated an increasing trend of 1.7 percent of the median per year or $6.89 \mathrm{mg} / \mathrm{L}$. The use of the seasonal kendall tau test on $\mathrm{raw}$ data would indicate a different conclusion, that no trend occurred in dissolved solids. The measured trend at Verde River near Camp Verde appears to have been at its maximum during 1976-80 and then to have leveled off during 1981-84 (fig. 4).

No significant trend of dissolved-solids concentrations was found at the Oak Creek or Wet Bottom Creek sites. The mean dissolved-solids concentrations of the Oak Creek and Wet Bottom Creek sites (152 and 162 $\mathrm{mg} / \mathrm{L}$ ) are more than 50 percent less than that of the Verde River near Camp Verde site. Streamflow from Wet Bottom Creek and the East Verde River contains small concentrations of dissolved solids. This streamflow dilutes the large dissolved-solids concentrations measured at the Verde River near 
Table 5. - Results of ordinary least-squares regression analys is and seasonal Kendall tau test of water-qual ity data

CResults follow the general linear model form $f(c)=\beta_{0}+\beta_{1} \cdot f(Q)+\beta_{2} T+c$, where $f(c)=c$ (LIN) or $f(c)=\ln (c)(L O G)$ and $f(Q)$ is one of the following functions of water discharge: (inear (LIN),

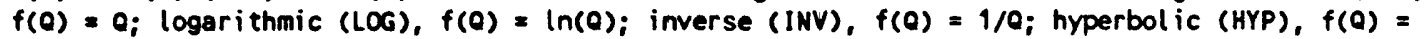
$1 /(1+\beta-0)$ and $T=$ date of sample]

\begin{tabular}{|c|c|c|c|c|c|c|c|c|c|}
\hline \multirow[b]{2}{*}{$\begin{array}{l}\text { Station name and number } \\
\text { and period of record }\end{array}$} & \multicolumn{4}{|c|}{$\begin{array}{l}\text { Ordinary least-squares regression } \\
\text { analysis using concentration as } \\
\text { a function of discharge and time }\end{array}$} & \multicolumn{3}{|c|}{$\begin{array}{l}\text { Seasonal Kendall tau } \\
\text { test on raw } \\
\text { concentration data }\end{array}$} & \multicolumn{2}{|c|}{$\begin{array}{c}\text { Seasonal Kendall tau test } \\
\text { on discharge- adjusted } \\
\text { concentration data }\end{array}$} \\
\hline & $\begin{array}{l}f(c) / \\
f(0)\end{array}$ & $R^{2}$ & $\beta_{2}$ & p value & $\begin{array}{l}\text { Median } \\
\text { concen } \\
\text { tration }\end{array}$ & $\begin{array}{l}\text { Trend } \\
\text { (mg/l) } \\
\text { /yr }\end{array}$ & p value & $\begin{array}{l}\text { Trend } \\
(m g / L) / y r^{1}\end{array}$ & p value \\
\hline
\end{tabular}

Dissolved solids, in milligrams per liter [<, less than]

Verde River near
Clarkdale 09504000
$(3 / 76-10 / 83$,
$10 / 86-3 / 87)$
Oak Creek at Red Rock
Crossing near Sedona
O9504440 (10/78-10/83,
$10 / 86-3 / 87)$
Verde River near Camp
Verde 09506000
(10/78-9/84)
Het Botton Creek near
Childs 09508300
( $8 / 68-3 / 87)$
Verde River below
Tangle Creek above
Horseshoe Dam 09508500
(10/80-3/87)
Verde River below
Bartlett Dan 09510000
(12/50-3/87)
Do.
(12/50-11/80)
Do.
$(12 / 80-3 / 87)$

$\begin{array}{lllll}\text { LIN/ } & & & & \\ \text { INV } & 0.818 & 1.70 & 0.09 & 265\end{array}$

$\begin{array}{lllll}\text { INV } & 0.818 & 1.70 & 0.09 & 265\end{array}$

Log/

$\begin{array}{lllll}\text { LOG } & .886 & -.001 & .632 & 161\end{array}$

Log/

LOG

.897

$.008 \quad .028$

410

LIN/

HYP

.786

.73

.227

170

.001

348

$.899 \quad \cdot .035$

LIN/

LOG

.30

$-2.53$

$<.001$

318

LIN/

$\begin{array}{lllll}\text { HYP } & .326 & -2.96 & <.001 & 326\end{array}$

No relation between discharge and concentration

\begin{tabular}{|c|c|c|c|}
\hline-2.75 & 0.2171 & 0.65 & .3485 \\
\hline-1.70 & .2774 & $\begin{array}{r}.19 \\
1.80\end{array}$ & 1.0000 \\
\hline$\cdot 7.67$ & .2168 & $\begin{array}{l}6.89 \\
66.0\end{array}$ & .0439 \\
\hline$\cdot .39$ & .7421 & .43 & .4113 \\
\hline-4.38 & .0476 & $\begin{array}{l}-6.51 \\
-48.0\end{array}$ & .0276 \\
\hline-2.43 & .0045 & -2.25 & .0015 \\
\hline-3.1 & .0047 & -2.92 & .0047 \\
\hline-14.3 & .0867 & -14.3 & .0867 \\
\hline
\end{tabular}

See footnotes at end of table. 
Table 5. - Results of ordinary least-squares rearession analysis and seasonal Kendall tau test of mater-quality data - Continued

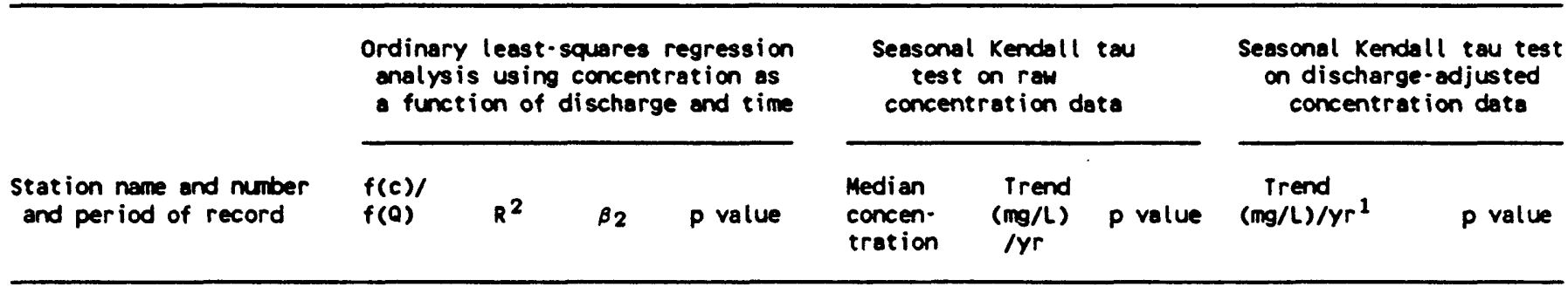

Dissolved sulfote, in milligrams per liter

[c, less than]

\begin{tabular}{|c|c|c|c|c|c|c|c|c|c|}
\hline $\begin{array}{l}\text { Verde River near } \\
\text { Clorkdole } 09504000 \\
(3 / 76-10 / 83 \\
10 / 86-3 / 87)\end{array}$ & $\begin{array}{l}\text { LIN/ } \\
\text { LIN }\end{array}$ & 0.119 & -0.031 & 0.700 & 9.4 & -0.01 & 1.0000 & 0.06 & 0.7707 \\
\hline $\begin{array}{l}\text { Oak Creek at Red Rock } \\
\text { Crossing near Sedona } \\
09504440(10 / 78 \cdot 10 / 83 \text {, } \\
10 / 86 \cdot 3 / 87)\end{array}$ & $\begin{array}{l}\text { LIN/ } \\
\text { HYP }\end{array}$ & .132 & -.048 & .740 & 3.8 & $\cdot .24$ & .6035 & $\cdot .30$ & .6035 \\
\hline $\begin{array}{l}\text { Verde River near Camp } \\
\text { Verde } 09506000 \\
(10 / 78 \cdot 9 / 84)\end{array}$ & $\begin{array}{l}\text { LOG/ } \\
\text { HYP }\end{array}$ & .902 & .021 & .001 & 92.0 & 0 & .8499 & $\begin{array}{l}3.59 \\
37.6\end{array}$ & .2609 \\
\hline $\begin{array}{l}\text { Wet Botton Creek near } \\
\text { Childs 09508300 } \\
(8 / 68-3 / 87)\end{array}$ & $\begin{array}{l}\text { LOG/ } \\
\text { HYP }\end{array}$ & .219 & $\cdot .010$ & .003 & 8.4 & .09 & .2253 & $\begin{array}{r}. .15 \\
.3 .68\end{array}$ & .0201 \\
\hline $\begin{array}{l}\text { Verde River below } \\
\text { Tangle Creek above } \\
\text { Horseshoe Dam } 09508500 \\
(10 / 80-3 / 87)\end{array}$ & $\begin{array}{l}\text { LOG/ } \\
\text { LOG }\end{array}$ & .882 & -.026 & .001 & 62.5 & -2.46 & .1107 & $\begin{array}{l}-3.44 \\
-28.6\end{array}$ & .0006 \\
\hline $\begin{array}{l}\text { Verde River below } \\
\text { Bartlett Dam } 0951000 \\
(12 / 50-3 / 87)\end{array}$ & $\operatorname{LIN/}_{\text {HYP }}$ & .267 & $\cdot .59$ & $<.001$ & 55.0 & $\cdot .53$ & .0098 & $\cdot .45$ & .0094 \\
\hline $\begin{array}{c}\text { Do. } \\
(12 / 50-11 / 80)\end{array}$ & $\begin{array}{l}\text { LIN/ } \\
\text { LOG }\end{array}$ & .303 & $\cdot .718$ & $<.001$ & 57.0 & -.64 & .0054 & $\cdot .60$ & .0036 \\
\hline $\begin{array}{c}\text { Do. } \\
(12 / 80-3 / 87)\end{array}$ & $\begin{array}{l}\text { No } r \\
\text { and }\end{array}$ & $\begin{array}{l}\text { otion b } \\
\text { oncent } r\end{array}$ & $\begin{array}{l}\text { tween di } \\
\text { tion }\end{array}$ & scharge & 45.0 & .5 .20 & .0659 & -5.20 & .0659 \\
\hline
\end{tabular}

See footnotes ot end of table. 
Table 5.- -Results of ordinary least-squares regression analysis and seasonal Kendall tau test of hater-quality data--Cont inued

\begin{tabular}{|c|c|c|c|c|c|c|c|c|c|}
\hline \multirow[b]{2}{*}{$\begin{array}{l}\text { Station name and number } \\
\text { and period of record }\end{array}$} & \multicolumn{4}{|c|}{$\begin{array}{l}\text { Ordinary least-squares regression } \\
\text { analysis using concentration as } \\
\text { a function of discharge and time }\end{array}$} & \multicolumn{3}{|c|}{$\begin{array}{l}\text { Seasonal Kendall tau } \\
\text { test on raw } \\
\text { concentration data }\end{array}$} & \multicolumn{2}{|c|}{$\begin{array}{l}\text { Seasonal Kendall tau test } \\
\text { on discharge-adjusted } \\
\text { concentration data }\end{array}$} \\
\hline & $\begin{array}{l}f(c) / \\
f(Q)\end{array}$ & $R^{2}$ & $\boldsymbol{B}_{2}$ & P value & $\begin{array}{l}\text { Median } \\
\text { concen: } \\
\text { tration }\end{array}$ & $\begin{array}{l}\text { Trend } \\
(\mu g / L) \\
/ y r\end{array}$ & P value & $\begin{array}{c}\text { Trend } \\
(\mu g / L) / y r^{1}\end{array}$ & p value \\
\hline
\end{tabular}

Dissolved arsenic, in micrograms per liter

$[<$, less than]

Verde River near

Clarkdale 09504000

(3/76-10/83,

$10 / 86-3 / 87)$

Dak Creek at Red Rock

Crossing near Sedona

09504440 (10/78 $10 / 83$,

$10 / 86 \cdot 3 / 87$ )

Verde River near Camp

Verde 09506000

$(10 / 78-9 / 84)$

Wet Botton Creek near Childs 09508300

$(8 / 68 \cdot 3 / 87)$

Verde River below

Tangle Creek above LOG

Horseshoe Dam

09508500 (10/80-3/87)

Verde River below

Bart lett Dan 09510000

$(1 / 74 \cdot 3 / 87)$

Do.

$(1 / 74-11 / 80)$

Do.

$(12 / 80-3 / 87)$
Insufficent data

Insufficient data

Insufficient data

\section{LOG/}

$\begin{array}{lllll}\text { LOG } & 0.812 & .022 & 0.083 & 8.0\end{array}$

.45

.6535

.80

0.1928

LIN/

16.0

$-.50 \quad .8201$

$\cdot .69$

.8286

LIN/

$.245 \quad . .195 \quad .070$

$\because .12 \quad .4590$

$\cdot .17$

.1437

LIN/

LOG $\quad .532 \quad \cdot .692 \quad .054$

13.0

$1.42 \quad .1587$

$-.84$

.1752

No relation between discharge and concentration

12.0

$0<1.0000$

0

$<1.0000$

See footnotes at end of table. 
Table 5. - Results of ordinary least-squares regression and seasonal Kendall trend analyses of water-qual ity data - Cont inued

\begin{tabular}{|c|c|c|c|c|c|c|c|c|c|}
\hline \multirow[b]{2}{*}{$\begin{array}{l}\text { Station name and number } \\
\text { and period of record }\end{array}$} & \multicolumn{4}{|c|}{$\begin{array}{l}\text { Ordinary least-squares regression } \\
\text { analysis using concentration as } \\
\text { anction of discharge and time }\end{array}$} & \multicolumn{3}{|c|}{$\begin{array}{l}\text { Seasonal Kendall tau } \\
\text { test on raw } \\
\text { concentration data }\end{array}$} & \multicolumn{2}{|c|}{$\begin{array}{l}\text { Seasonal Kendall tau test } \\
\text { on discharge-adjusted } \\
\text { concentration data }\end{array}$} \\
\hline & $\begin{array}{l}f(c) / \\
f(0)\end{array}$ & $R^{2}$ & $\boldsymbol{\beta}_{2}$ & p value & $\begin{array}{l}\text { Median } \\
\text { concen- } \\
\text { tration }\end{array}$ & $\begin{array}{l}\text { Trend } \\
\text { (mg/l) } \\
\text { /yr }\end{array}$ & p value & $\begin{array}{l}\text { Trend } \\
(m g / L) / y r^{1}\end{array}$ & p value \\
\hline
\end{tabular}

Total phosphorus, in milligrams per liter

$[<$, less than,]

\begin{tabular}{|c|c|c|c|c|c|c|c|c|}
\hline $\begin{array}{l}\text { Verde River near } \\
\text { Clarkdale } 09504000 \\
(3 / 76-10 / 83 \\
10 / 86-3 / 87)\end{array}$ & $\begin{array}{l}\text { LOG/ } \\
\text { HYP }\end{array}$ & $\cdot 0.0249$ & 0.161 & 0.04 & 0 & $<1.0000$ & $\begin{array}{r}.0 .002 \\
\cdot .039\end{array}$ & 0.1093 \\
\hline $\begin{array}{l}\text { Oak Creek at Red Rock } \\
\text { Crossing near Sedona } \\
09504440(10 / 78-10 / 83 \text {, } \\
10 / 86-3 / 87)\end{array}$ & \multicolumn{3}{|c|}{$\begin{array}{l}\text { No relation between discharge } \\
\text { and concentration }\end{array}$} & .03 & 0 & .8234 & 0 & .9407 \\
\hline $\begin{array}{l}\text { Verde River near Camp } \\
\text { Verde 09506000 } \\
(10 / 78 \cdot 9 / 84)\end{array}$ & \multicolumn{3}{|c|}{$\begin{array}{l}\text { No relation between discharge } \\
\text { and concentration }\end{array}$} & .05 & .003 & .4449 & .003 & .4449 \\
\hline $\begin{array}{l}\text { Wet Botton Creek near } \\
\text { Childs 09508300 } \\
(8 / 68 \cdot 3 / 87)\end{array}$ & \multicolumn{3}{|c|}{$\begin{array}{l}\text { No relation between discharge } \\
\text { and concentration }\end{array}$} & .01 & 0 & .7023 & 0 & .5480 \\
\hline $\begin{array}{l}\text { Verde River below } \\
\text { Tangle Creek above } \\
\text { Horseshoe Dam } \\
09508500(10 / 80-3 / 87)\end{array}$ & $\begin{array}{l}\text { LOG/ } \\
\text { LOG }\end{array}$ & $\bullet .0019$ & .497 & .04 & $\cdot .002$ & .4494 & $\begin{array}{r}<-.001 \\
\cdot .001\end{array}$ & .0977 \\
\hline $\begin{array}{l}\text { Verde River below } \\
\text { Bartlett Dam } 09510000 \\
(1 / 74 \cdot 3 / 87)\end{array}$ & \multicolumn{3}{|c|}{$\begin{array}{l}\text { No relation between discharge } \\
\text { and concentration }\end{array}$} & .05 & $\cdot .001$ & .2403 & -.001 & .2403 \\
\hline $\begin{array}{l}\text { Do. } \\
(1 / 74 \cdot 11 / 80)\end{array}$ & \multicolumn{3}{|c|}{$\begin{array}{l}\text { No relation between discharge } \\
\text { and concentration }\end{array}$} & .05 & .004 & .1486 & .004 & .1486 \\
\hline $\begin{array}{l}\text { Do. } \\
(12 / 80 \cdot 3 / 87)\end{array}$ & \multicolumn{3}{|c|}{$\begin{array}{l}\text { No relation between discharge } \\
\text { and concentration }\end{array}$} & .04 & $\cdot .007$ & .0056 & $\cdot .007$ & .0037 \\
\hline
\end{tabular}

See footnotes at end of table. 
Table 5.- Results of ordinary least-squares regression and seasonal Kendall trend analyses of water-qual ity data--Cont inued

\begin{tabular}{|c|c|c|c|c|c|c|c|c|c|}
\hline \multirow[b]{2}{*}{$\begin{array}{l}\text { Station name and number } \\
\text { and period of record }\end{array}$} & \multicolumn{4}{|c|}{$\begin{array}{l}\text { Ordinary least-squares regression } \\
\text { analysis using concentration as } \\
\text { a function of discharge and time }\end{array}$} & \multicolumn{3}{|c|}{$\begin{array}{l}\text { Seasonal Kendall tau } \\
\text { test on raw } \\
\text { concentration data }\end{array}$} & \multicolumn{2}{|c|}{$\begin{array}{l}\text { Seasonal Kendall tau test } \\
\text { on discharge:adjusted } \\
\text { concentration data }\end{array}$} \\
\hline & $\begin{array}{l}f(c) / \\
f(Q)\end{array}$ & $\mathrm{R}^{2}$ & $\beta_{2}$ & $p$ value & $\begin{array}{l}\text { Median } \\
\text { concen- } \\
\text { tration }\end{array}$ & $\begin{array}{l}\text { Trend } \\
\text { percent } \\
\text { change } \\
\text { /yr }\end{array}$ & p value & $\begin{array}{l}\text { Trend } \\
\text { percent } \\
\text { change } \\
\text { /yr }\end{array}$ & $p$ value \\
\hline \multicolumn{10}{|c|}{$\begin{array}{l}\text { pH, in standard units } \\
{[<, \text { less than] }}\end{array}$} \\
\hline $\begin{array}{l}\text { Verde River near } \\
\text { Clarkdale } 09504000 \\
(3 / 76-10 / 83 \\
10 / 86-3 / 87)\end{array}$ & $\begin{array}{l}\text { LOG/ } \\
\text { LOG }\end{array}$ & 0.307 & 0.015 & 0.087 & 8.20 & 0 & 0.4791 & $\begin{array}{l}2.88 \\
40.6\end{array}$ & 0.1501 \\
\hline $\begin{array}{l}\text { Oak Creek at Red Rock } \\
\text { Crossing near Sedona } \\
09504440(10 / 78-10 / 83 \text {, } \\
10 / 86-3 / 87)\end{array}$ & $\begin{array}{l}\text { LOG/ } \\
\text { HYP }\end{array}$ & .161 & .006 & .738 & 8.29 & 0 & .7154 & 0 & $<1.0000$ \\
\hline $\begin{array}{l}\text { Verde River near Camp } \\
\text { Verde } 09506000 \\
(10 / 78 \cdot 9 / 84)\end{array}$ & $\begin{array}{l}\text { LOG/ } \\
\text { LIN }\end{array}$ & .284 & .020 & .162 & 8.30 & 2.56 & .2987 & $\begin{array}{l}3.51 \\
27.4\end{array}$ & .0674 \\
\hline $\begin{array}{l}\text { Wet Bottom Creek near } \\
\text { Childs 09508300 } \\
(8 / 68-3 / 87)\end{array}$ & \multicolumn{4}{|c|}{$\begin{array}{l}\text { No relation between discharge } \\
\text { and concentration }\end{array}$} & 7.90 & 5.93 & .1306 & 5.93 & .1306 \\
\hline $\begin{array}{l}\text { Verde River below } \\
\text { Tangle Creek above } \\
\text { Horseshoe Dam } 09508500 \\
(10 / 80-3 / 87)\end{array}$ & \multicolumn{4}{|c|}{$\begin{array}{l}\text { No relation between discharge } \\
\text { and concentration }\end{array}$} & 8.45 & 2.33 & .6061 & 2.33 & .6061 \\
\hline $\begin{array}{l}\text { Verde River below } \\
\text { Bartlett Dam } 09510000 \\
(12 / 50 \cdot 3 / 87)\end{array}$ & \multicolumn{4}{|c|}{$\begin{array}{l}\text { No relation between discharge } \\
\text { and concentration }\end{array}$} & 8.05 & 1.86 & .0044 & 1.86 & .0045 \\
\hline $\begin{array}{l}\text { Do. } \\
(12 / 50-11 / 80)\end{array}$ & \multicolumn{4}{|c|}{$\begin{array}{l}\text { No relation between discharge } \\
\text { and concentration }\end{array}$} & 8.05 & 1.39 & .0737 & 1.39 & .0625 \\
\hline $\begin{array}{c}\text { Do. } \\
(12 / 80 \cdot 3 / 87)\end{array}$ & $\begin{array}{l}\text { LOG/ } \\
\text { HYP }\end{array}$ & .243 & .015 & .562 & 8.30 & 5.93 & .3947 & $\begin{array}{r}-.23 \\
-1.62\end{array}$ & $<1.0000$ \\
\hline
\end{tabular}


Table 5.- - Results of ordinary least-squares rearession and seasonal Kendall trend analyses of mater-quality data - Cont inued

\begin{tabular}{|c|c|c|c|c|c|c|c|c|c|}
\hline \multirow[b]{2}{*}{$\begin{array}{l}\text { Station name and number } \\
\text { and period of record }\end{array}$} & \multicolumn{4}{|c|}{$\begin{array}{l}\text { Ordinary least-squares regression } \\
\text { analysis using concentration as } \\
\text { a function of discharge and time }\end{array}$} & \multicolumn{3}{|c|}{$\begin{array}{l}\text { Seasonal Kendall tau } \\
\text { test on raw } \\
\text { concentration data }\end{array}$} & \multicolumn{2}{|c|}{$\begin{array}{l}\text { Seasonal Kendall tau test } \\
\text { on discharge-adjusted } \\
\text { concentration data }\end{array}$} \\
\hline & $\begin{array}{l}f(c) / \\
f(Q)\end{array}$ & $R^{2}$ & $\beta_{2}$ & p value & $\begin{array}{l}\text { Median } \\
\text { concen- } \\
\text { tration }\end{array}$ & $\begin{array}{l}\text { Trend } \\
\text { (mg/l) } \\
\text { /yr }\end{array}$ & p value & $\begin{array}{l}\text { Trend } \\
(m g / L) / y r^{2}\end{array}$ & p value \\
\hline
\end{tabular}

Nitrogen (nitrite plus nitrate), in milligrams per liter

$[<$, less than; $>$, greater than]

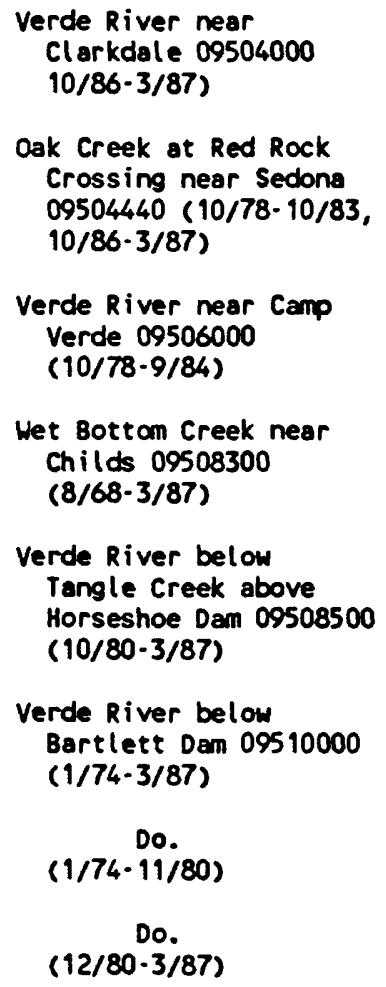

No relation between discharge and concentration

0.105

$-0.003$

0.5448

$-0.003$

0.5906

LIN/

HYP

0.127

$<0.001$

.761

.050

(2)

.3815

(2)

.3515

No relation between discharge and concentration

$$
.050
$$

0

1.0000

0

$<1.0000$

LIN/

$\begin{array}{lllll}\text { HYP } & .134 & \cdot .001 & .839\end{array}$

.030

.00

.2117

.005

.1031

No relation between discharge and concentration

.050

0

.1908

0

.1908

No relation between discharge and concentration

.080

$\cdot .004$

.0778

$\cdot .004$

.0778

No relation between discharge and concentration

.100

.00

.7099

.004

.6544

LOG/

HYP $\quad .547 \quad-.030<.001$

.050

$\cdot .013 \cdot .0071$

$-.001$

.1643

See footnotes at end of table. 
Table 5. - Results of ordinary least-squares regression and seasonal Kendall trend analyses

of water-quality data - Cont inued

\begin{tabular}{|c|c|c|c|c|c|c|c|c|c|}
\hline \multirow[b]{2}{*}{$\begin{array}{l}\text { Station name and number } \\
\text { and period of record }\end{array}$} & \multicolumn{4}{|c|}{$\begin{array}{l}\text { Ordinary least-squares regression } \\
\text { andlys is using concentration as } \\
\text { - function of discharge and time }\end{array}$} & \multicolumn{3}{|c|}{$\begin{array}{l}\text { Seasonal Kendall tau } \\
\text { test on raw } \\
\text { concentration data }\end{array}$} & \multicolumn{2}{|c|}{$\begin{array}{l}\text { Seasonal Kendall tau test } \\
\text { on discharge-adjusted } \\
\text { concentration data }\end{array}$} \\
\hline & $\begin{array}{l}f(c) / \\
f(Q)\end{array}$ & $R^{2}$ & $B_{2}$ & p volue & $\begin{array}{l}\text { Median } \\
\text { concen- } \\
\text { tration }\end{array}$ & $\begin{array}{l}\text { Trend } \\
(\mu g / L) \\
/ y r\end{array}$ & $p$ value & $\begin{array}{l}\text { Trend } \\
(\mu g / L) / y r^{1}\end{array}$ & $p$ value \\
\hline \multicolumn{10}{|c|}{$\begin{array}{c}\text { Dissolved iron, in micrograms per liter } \\
{[<, \text { less than] }}\end{array}$} \\
\hline $\begin{array}{l}\text { Verde River near } \\
\text { Clarkdale } 09504000 \\
(3 / 76-10 / 83 \\
10 / 86 \cdot 3 / 87)\end{array}$ & $\operatorname{LINY}_{\text {HYP }}$ & 0.348 & -0.95 & .679 & 20.0 & $\cdot 1.30$ & 0.2329 & -3.18 & 0.1497 \\
\hline $\begin{array}{l}\text { Oak Creek ot Red Rock } \\
\text { Crossing near Sedona } \\
09504440(10 / 78 \cdot 10 / 83 \text {, } \\
10 / 86-3 / 87)\end{array}$ & $\operatorname{LIN/}_{\text {HYP }}$ & .325 & 3.90 & .056 & 37.5 & 1.66 & .2909 & 3.71 & .0774 \\
\hline $\begin{array}{l}\text { Verde River near Camp } \\
\text { Verde } 09506000 \\
(10 / 78-9 / 84)\end{array}$ & $\operatorname{LIN/}_{\text {HYP }}$ & .149 & -5.71 & .147 & 9.0 & 0 & $<1.0000$ & -0.85 & .4063 \\
\hline $\begin{array}{l}\text { Wet Botton Creek near } \\
\text { Childs 09508300 } \\
(8 / 68-3 / 87)\end{array}$ & $\begin{array}{l}\text { LOG/ } \\
\text { HYP }\end{array}$ & .340 & .039 & .001 & 40.0 & 0 & .7481 & $\begin{array}{l}2.57 \\
61.6\end{array}$ & .0406 \\
\hline $\begin{array}{l}\text { Verde River below } \\
\text { Tangle Creek above } \\
\text { Horseshoe Dan } \\
09508500 \\
(10 / 80 \cdot 3 / 87)\end{array}$ & $\begin{array}{l}\text { LIN/ } \\
\text { LOG }\end{array}$ & .530 & 1.03 & .392 & 6.0 & 0 & .8765 & .66 & .8184 \\
\hline $\begin{array}{l}\text { Verde River below } \\
\text { Bartlett Dam } 09510000 \\
(1 / 68 \cdot 3 / 87)\end{array}$ & \multicolumn{4}{|c|}{$\begin{array}{l}\text { No relation between discharge } \\
\text { and concentration }\end{array}$} & 12.0 & -1.12 & .0022 & $\cdot 1.12$ & .0019 \\
\hline $\begin{array}{l}\text { Do. } \\
(1 / 68-11 / 80)\end{array}$ & \multicolumn{4}{|c|}{$\begin{array}{l}\text { No relation between discharge } \\
\text { and concentration }\end{array}$} & 20.0 & -1.43 & .0743 & -1.43 & .0743 \\
\hline $\begin{array}{l}\text { Do. } \\
(12 / 80 \cdot 3 / 87)\end{array}$ & \multicolumn{4}{|c|}{$\begin{array}{l}\text { No relation between discharge } \\
\text { and concentration }\end{array}$} & 5.5 & -1.12 & .0660 & -1.12 & .0660 \\
\hline
\end{tabular}

See footnotes at end of table. 
Table 5. - Results of ordinary least-squares regression and seasonal Kendall trend analyses of water-cual ity data - Cont inued

Station name and number and period of record
Ordinary least-squares regression

enalysis using concentration as

- function of discharge and time

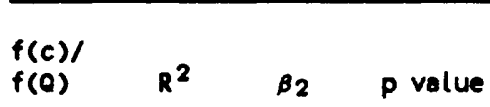

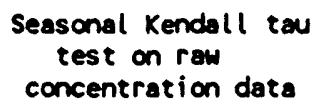

Seasonal Kendall tau

test on raw

concentration data

Medien Trend
concen. data
tration colonies

$100 \mathrm{ml} / \mathrm{yr}$

Seasonal Kendall tau test on discharge-adjusted concentration data

Trend
data
colonies
$100 \mathrm{ml} / \mathrm{yr}$

Fecal coliform bacteris, in colonies per 100 milliliters

[<, less than; >, greater than]

Verde River near
Clarkdale O9504000
(3/76-10/83,
$10 / 86-3 / 87)$
Oak Creek at Red Rock
Crossing near Sedona
O9504440 (10/78-10/83,
$10 / 86-3 / 87)$
Verde River near Camp
Verde 09506000
(10/78-9/84)
Het Bottom Creek near
Childs 09508300
(8/68-3/87)
Verde River below
Tangle Creek above
Horseshoe Dam 09508500
(10/80-3/87)
Verde River below
Bartlett Dam 09510000
(1/76-3/87)
Do.
(1/76-11/80)
Do.
(12/80-3/87)

No relation between discharge and concentration

10

12

$\begin{array}{llll}\operatorname{LOG} & .147 \quad-.048 \quad .233\end{array}$

No relation between discharge and concentration

No relation between discharge and concentration

No relation between discharge and concentration

20

.80

.5301

.80

No relation between discharge and concentration

2.5

0

.5224

0

LoG/

HYP

$.205 \quad .012 \quad .870$

1

.25

.5322

.009

.047

No relation between discharge and concentration
. $.42 \quad .4198$

$-.42$

Where two values are given, first value is rate for 1 year, second value is rate of change for period of record for which constituent was sampled for.

Zata contains several "less than" values. 

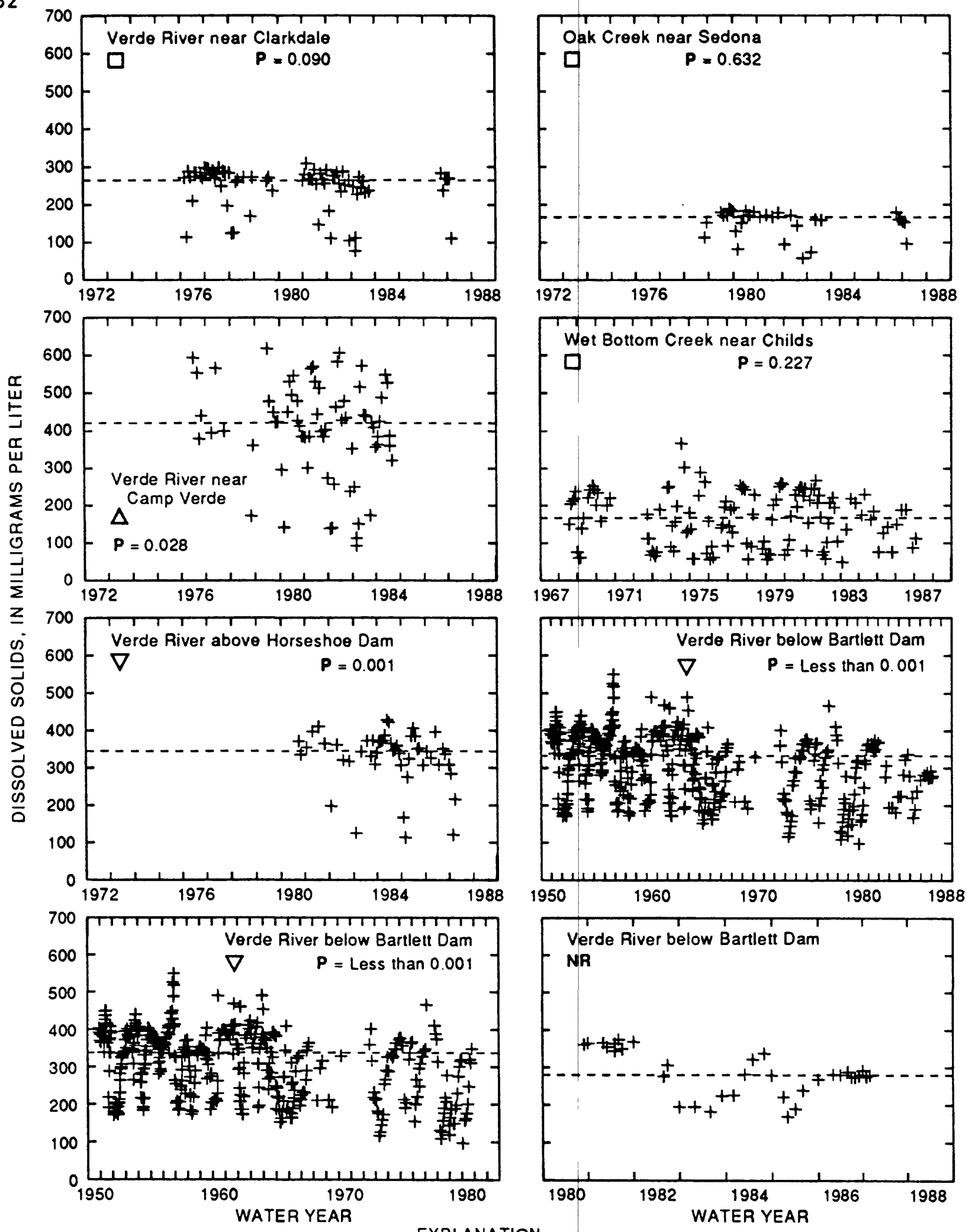

EXPLANATION

TREND-SIGNIFICANCE LEVEL, IN PERCENT:

NR NO RELATION BETWEEN DISCHARGE AND CONCENTRATION

Greater than 95, triangle orientation indicates trend direction

$P$ P VALUE OR THE VARIABLE TIME IN THE REGRESSION OF DISCHARGE AND TIME ON CONCENTRATION

Less than 95

- - LINE INDICATES MEDIAN CONCENTRATION VALUES

Figure 4.-Temporal trends in dissolved-solids concentrations using the ordinary least-squares regression analysis. 

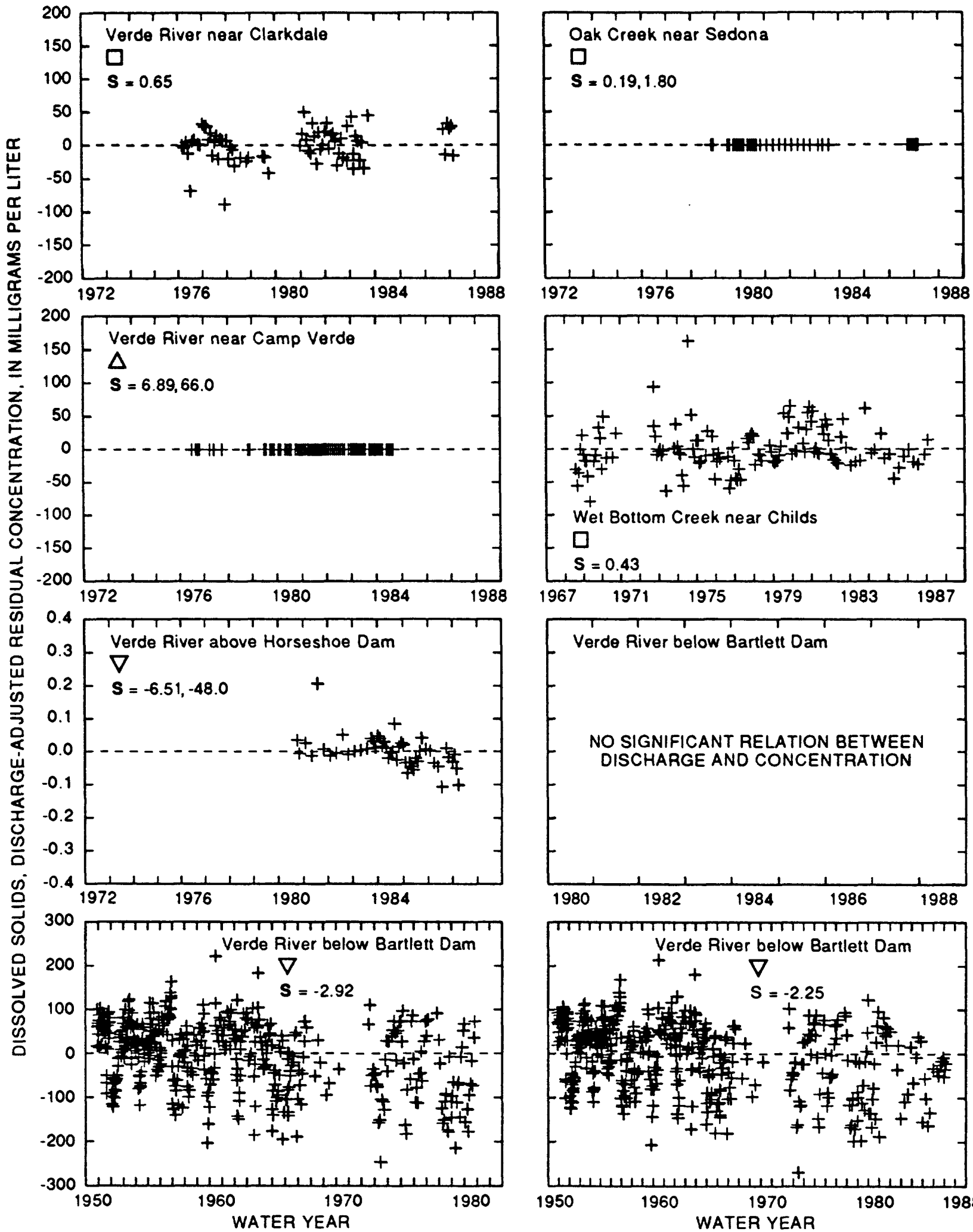

\section{EXPLANATION}

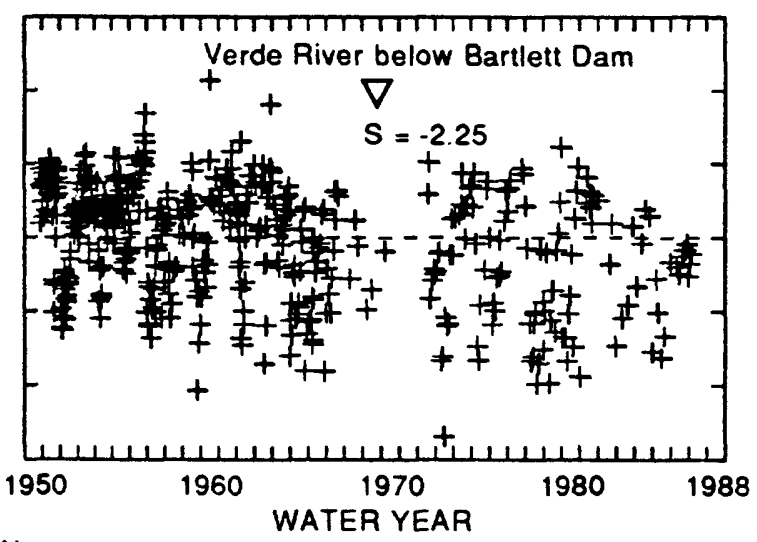

\footnotetext{
TREND-SIGNIFICANCE LEVEL, IN PERCENT:

$\nabla$ Greater than 95 , triangle orientation indicates trend direction

Less than 95
}

S TREND SLOPE IN MILLIGRAMS PER LITER. WHERE VARYING RATE OF CHANGE WAS COMPUTED. TWO VALUES ARE GIVEN; FIRST VALUE IS CHANGE FOR I YEAR AND SECOND VALUE IS CHANGE OVER SAMPLE COLLECTION PERIOD

Eigure 5.-Temporal trends in discharge-adjusted dissolved-solids concentrations using the seasonal Kendall tau test. 
Camp Verde site and results in smaller concentrations at the Verde River above Horseshoe Dam site.

At the Verde River below Tangle Creek above Horseshoe Dam site, a significant decrease in dissolved-solids concentrations of 2 percent of the median, $6.51(\mathrm{mg} / \mathrm{L}) / y r$, or $48.0 \mathrm{mg} / \mathrm{L}$ for the period of data collection, was measured using the seasonal Kendall tau test on DAC data. The results of the OLS regression analysis showed decreasing trends at similar significance levels. The computation of a decreasing trend at this site appears to be influenced by data collected during the 1985-87 water years. From 1985-87, data were not collected at the Verde River near Camp Verde site, which had an increasing trend prior to this period. If data collection had continued at the Camp Verde site through 1987, evaluation of data might have shown a reversal in trend direction to one that emulates the trend at Verde River below Tangle Creek above Horseshoe Dam.

Dissolved-solids concentrations for 1950 through November 1980 at the outlet from Bartlett Reservoir decreased 2.9 to 3.1 (mg/L)/yr, depending on the test used (table 5). The OLS regression analysis was not used for data collected from December 1980 through March 1987 because of the lack of correlation between discharge and dissolved-solids concentrations. Results from a seasonal Kendall tau test on raw data showed a decreasing trend of $14.3 \mathrm{mg} / \mathrm{L}$ with a $\mathrm{p}$ value of 0.0867 .

Data collection could be reinstated at the Verde River near Camp Verde site to determine if the increasing trend of dissolved-solids concentrations ceased as indicated by analysis of data from the downstream sites. Additional sampling of the Verde River and its tributaries between the Clarkdale and Camp Verde sites could identify source(s) of water containing large concentrations of dissolved solids in addition to those identified by Owen-Joyce (1984).

\section{Dissolved Sulfate}

The increasing trend in dissolved-sulfate concentrations at the Verde River near Camp Verde site downstream from the Verde River near Clarkdale site indicates that mine drainages, irrigation return flows, and (or) aquifers could be contributing water with large concentrations of dissolved sulfate to the Verde River. Significant increases in trend of dissolved-sulfate concentrations at the Verde River near Camp Verde site were calculated using OLS regression analysis (fig. 6). The seasonal Kendall tau test on DAC data (fig. 7) at the same site showed a similar increasing trend of $3.59(\mathrm{mg} / \mathrm{L}) / \mathrm{yr}$, or $37.6 \mathrm{mg} / \mathrm{L}$ for the period of data collection, although not at significant levels. A significant decrease in trend of an almost equal magnitude was calculated at the next station downstream, Verde River above Horseshoe Dam. The increasing trend in sulfate at the Verde River near Camp Verde site was influenced by data collected during the 1976-79 water years. Data collected during 1980-84 showed an apparent leveling of the trend. The decreasing trend at the Verde River above Horseshoe Dam site appears to have resulted from the small dissolved-sulfate concentrations in samples collected during the 198487 water years. Because of the different sample-collection periods at the two sites, the increasing trend at the upstream site and the decreasing trend at the downstream site are difficult to evaluate. A concurrent 

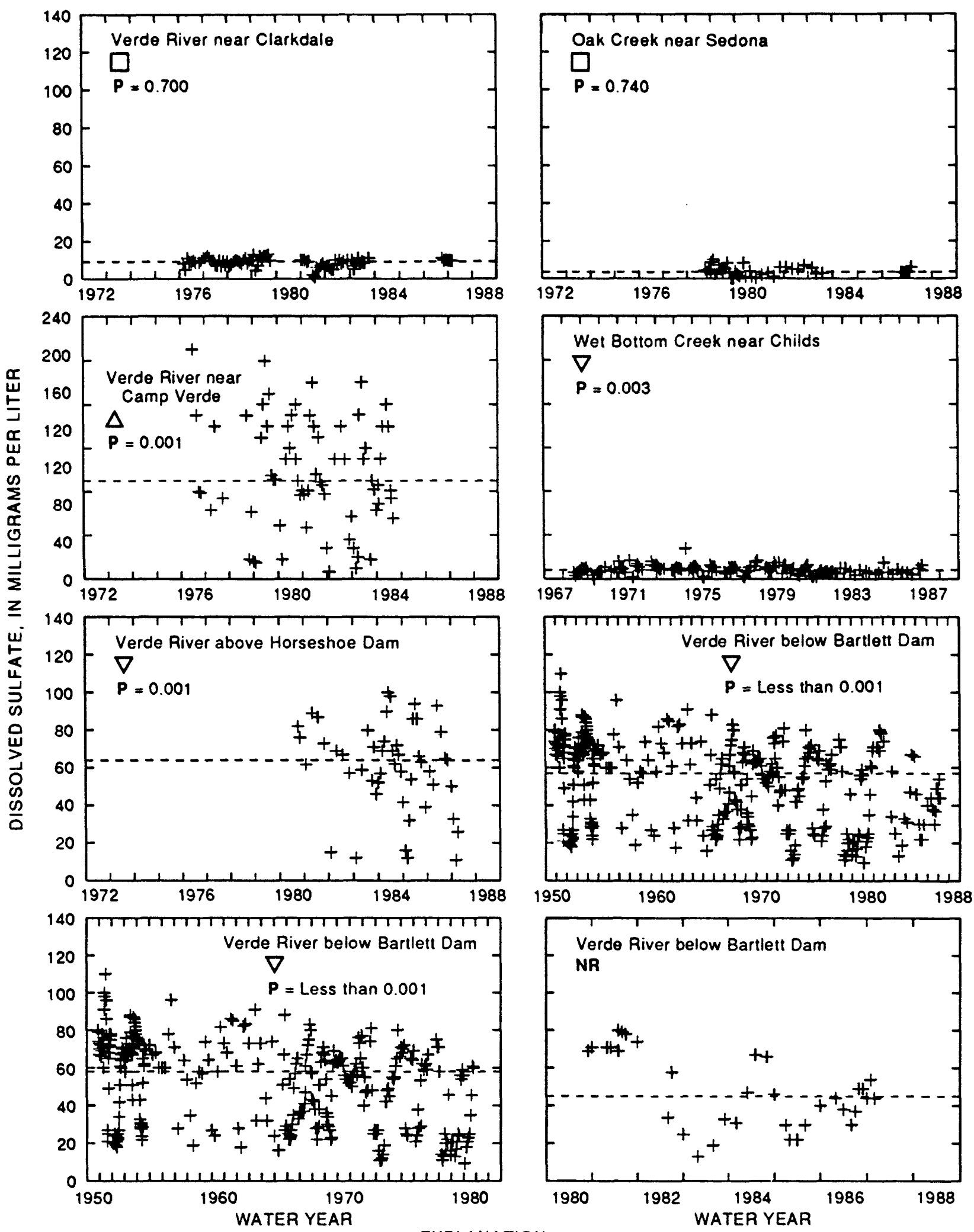

EXPLANATION

TREND-SIGNIFICANCE LEVEL, IN PERCENT:

NR NO RELATION BETWEEN DISCHARGE AND CONCENTRATION

P P VALUE OF THE VARIABLE TIME IN THE REGRESSION OF DISCHARGE AND TIME ON CONCENTRATION

- - LINE INDICATES MEDIAN CONCENTRATION VALUES

Eigure 6.-Temporal trends in dissolved-sulfate concentrations using the ordinary least-squares regression analysis. 

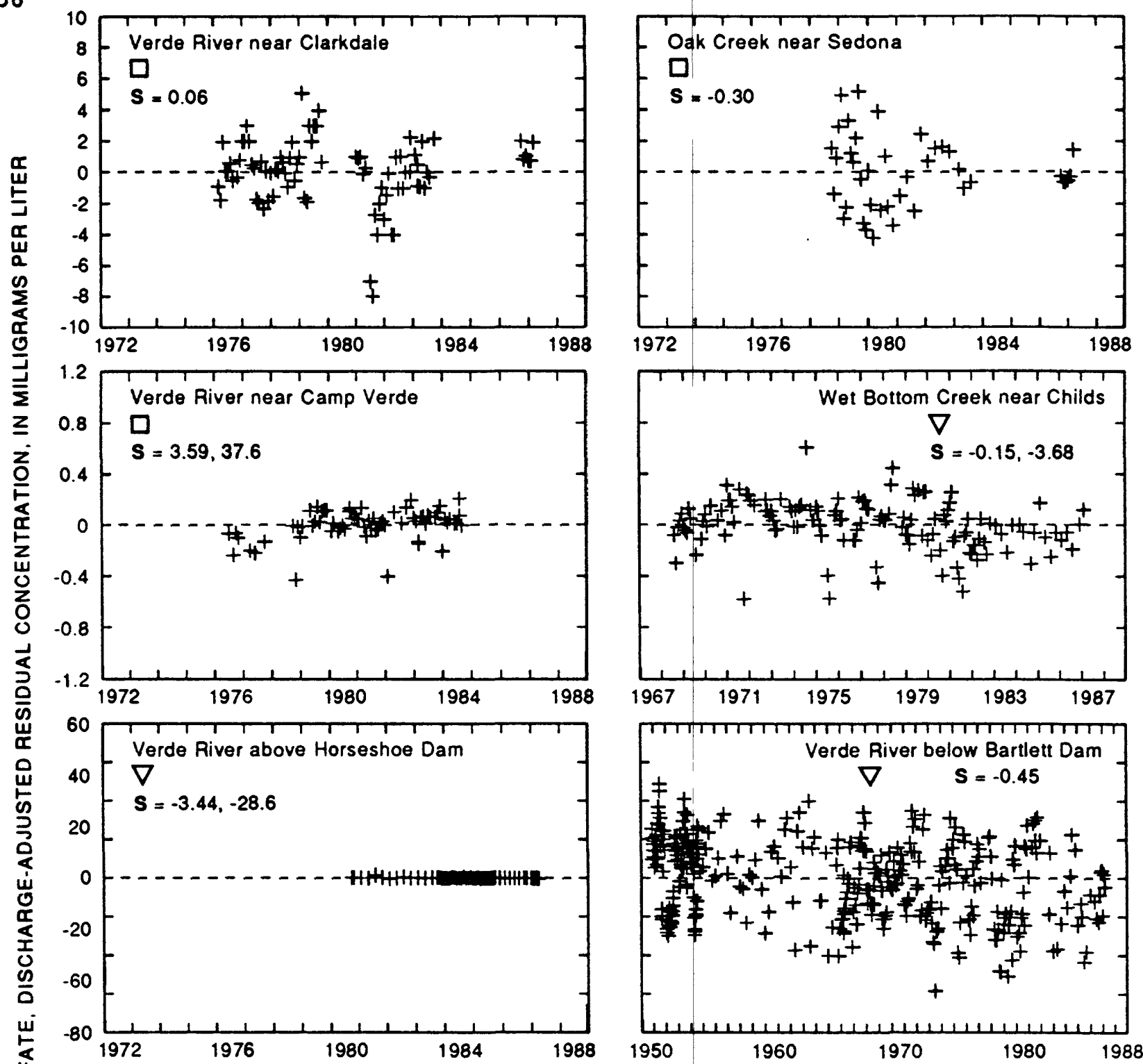

ज
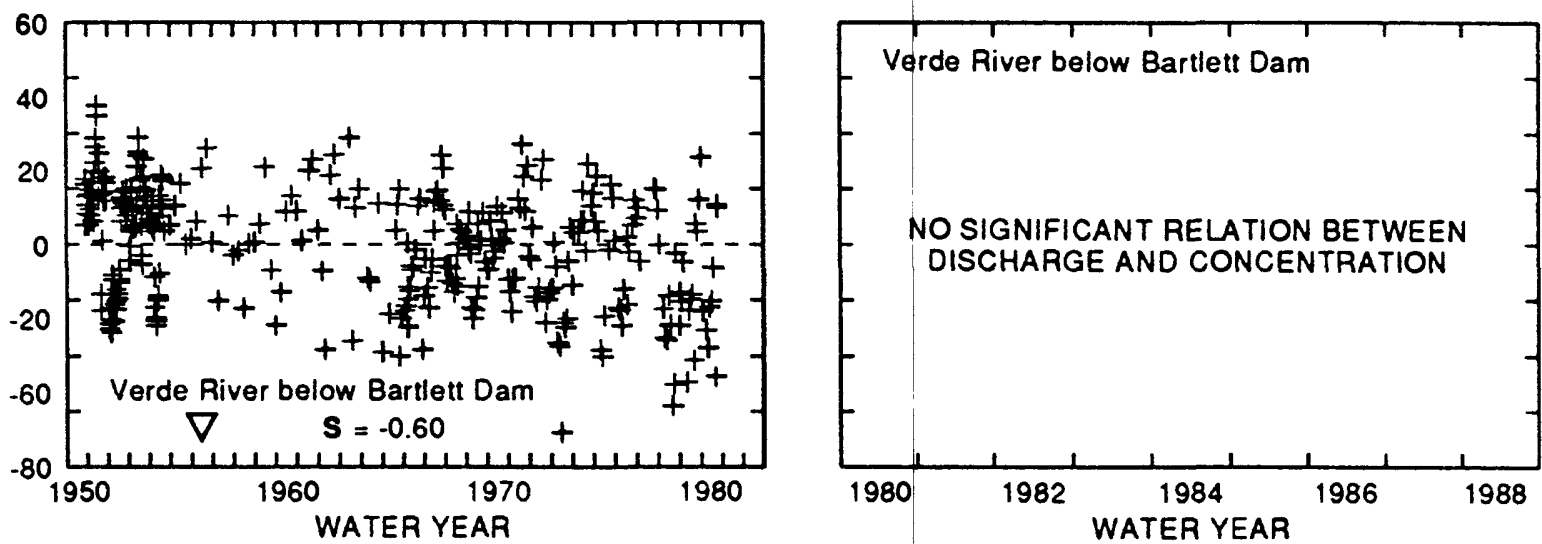

TREND-SIGNIFICANCE LEVEL, IN PERCENT:

EXPLANATION

S TREND SLOPE IN MILLIGRAMS PER LITER. WHERE VARYING RATE OF CHANGE WAS COMPUTED. TWO VALUES ARE GIVEN: FIRST VALUE IS CHANGE FOR 1 YEAR AND SECOND VALUE IS CHANGE OVER SAMPLE COLLECTION PERIOD

- - - LINE INDICATES MEDIAN CONCENTRATION VALUES

Figure 7.-Temporal trends in discharge-adjusted dissolved-sulfate concentrations using the seasonal Kendall tau test. 
sample-collection period for both sites is needed to evaluate trend direction and magnitude.

A decreasing trend at Wet Bottom Creek near Childs was calculated using the OLS regression analysis, $-0.01(\mathrm{mg} / \mathrm{L}) / \mathrm{yr}$, and the seasonal Kendall tau test, $-0.15(\mathrm{mg} / \mathrm{L}) / \mathrm{yr}$. Median dissolved-sulfate concentration at the site was $8.4 \mathrm{mg} / \mathrm{L}$, which is within recommended Environmental Protection Agency secondary standards for drinking water.

A decreasing trend in dissolved-sulfate concentrations was calculated for data collected at Verde River below Bartlett Dam, the next downstream site on the Verde River. The trend was calculated using three data sets: (1) data collected at both sites over the entire period of record, 1950-86; (2) data collected immediately below the dam, 1950 through November 1980; and (3) data collected $1.2 \mathrm{mi}$ downstream from the dam, December 1980 to March 1987. A significant trend of about 0.5 (mg/L)/yr was calculated for the first two data sets using OLS regression analysis and the seasonal Kendall tau test. The data set for December 1980 to March 1987 was evaluated only by the seasonal Kendall tau test because of the poor relation between discharge and dissolved-sulfate concentrations. A decrease of 5.2 $(\mathrm{mg} / \mathrm{L}) / \mathrm{yr}$ was calculated with a $\mathrm{p}$ value of 0.0659 for this data set.

\section{Dissolved Arsenic}

Trends in dissolved-arsenic concentrations were analyzed for only at the three downstream study sites (table 5) because of the lack of data collection at the other study sites. Results of OLS regression analysis showed an increase in trend at the Wet Bottom Creek site and decreases in trend at the other two sites. Trends measured by OLS regression analysis were not significant; however, if the level of significance in the $p$ value is lowered 0.05 , significant trends in dissolved arsenic would have been recorded for three of the four data sets (fig. 8). The seasonal Kendall tau test on raw concentration and DAC data found no trends with $p$ values of less than 0.0500 (fig. 9).

Additional samples need to be collected at the six sites. Three years of dissolved-arsenic data collected at Verde River above Horseshoe Dam satisfied the minimum number of samples required to perform the seasonal Kendall tau test. However, only six samples each were collected at the Verde River near Clarkdale and the Oak Creek near Sedona sites and none at the Verde River near Camp Verde site.

\section{Total Phosphorus}

In the study area, water quality is good with respect to an absence of increasing trends in total-phosphorus concentrations (table 5). Analysis of data did not indicate that flow containing large concentrations of total phosphorus resulting from agricultural and domestic fertilizers and leaking septic-tank systems was entering the Verde River in the Verde Valley region and causing increasing trends in total-phosphorus concentrations (fig. 10). A decreasing trend of 0.007 (mg/L)/yr in total-phosphorus concentrations using the seasonal Kendall tau test on DAC data was detected 

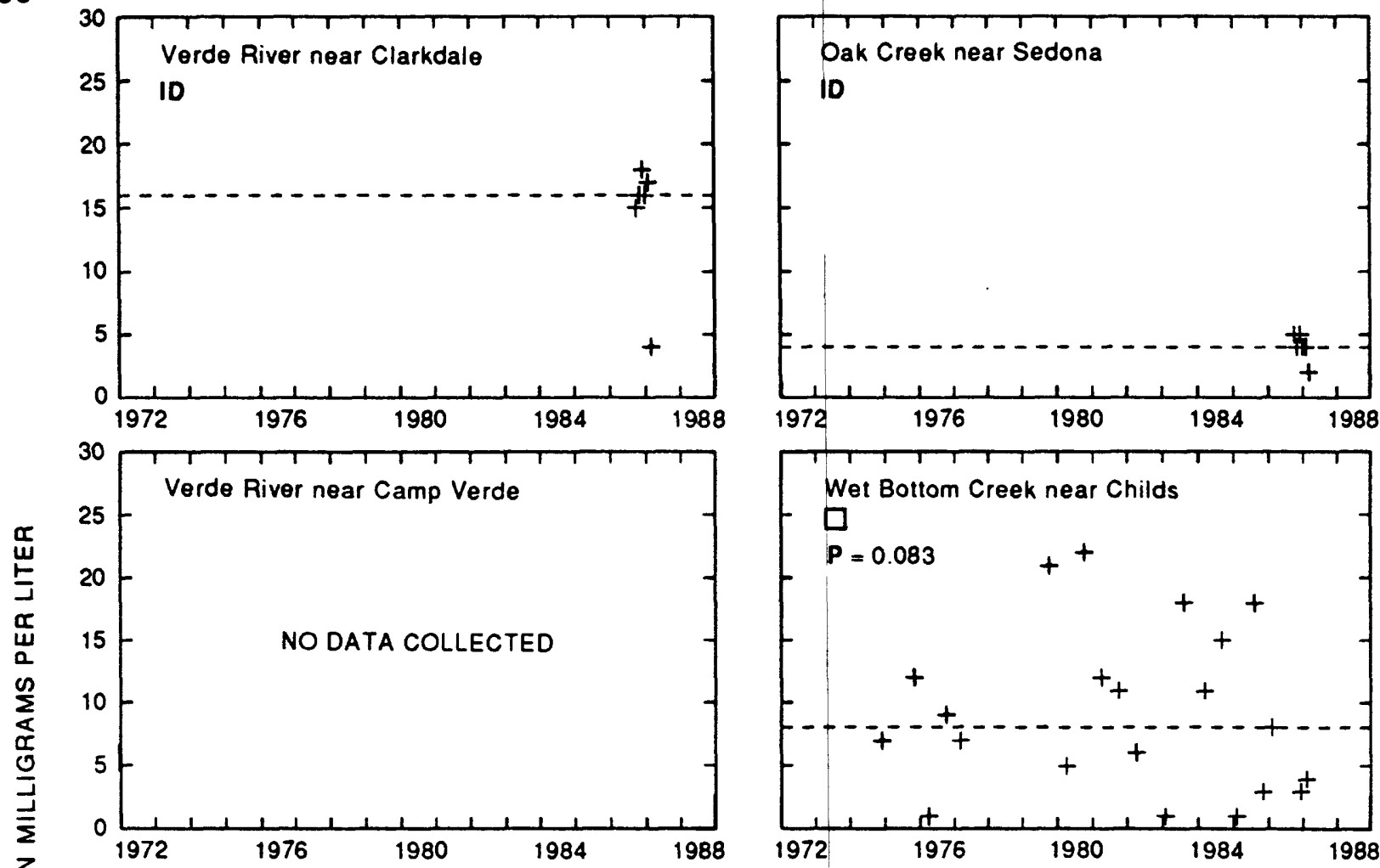

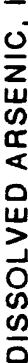
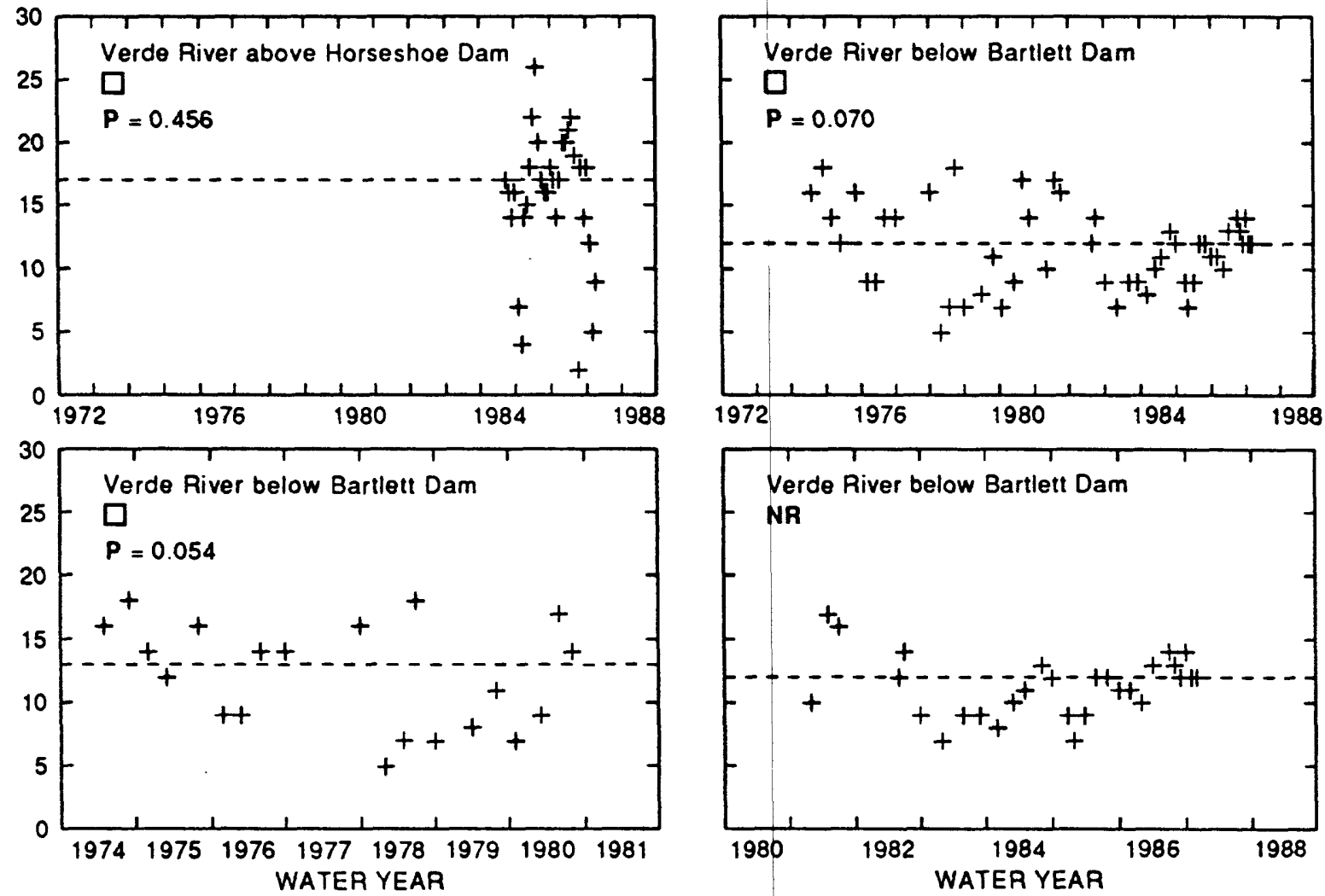

TREND-SIGNIFICANCE LEVEL, EXPLANATION

NR NO RELATION BETWEEN DISCHARGE AND CONCENTRATION Less than 95

ID INSUFFICIENT DATA

P P VALUE OF THE VARIABLE TIME IN THE REGRESSION OF DISCHARGE AND TIME ON CONCENTRATION

- - LINE INDICATES MEDIAN CONCENTRATION VALUES

Figure 8.-Temporal trends in dissolved-arsenic concentrations using the ordinary least-squares regression analysis. 

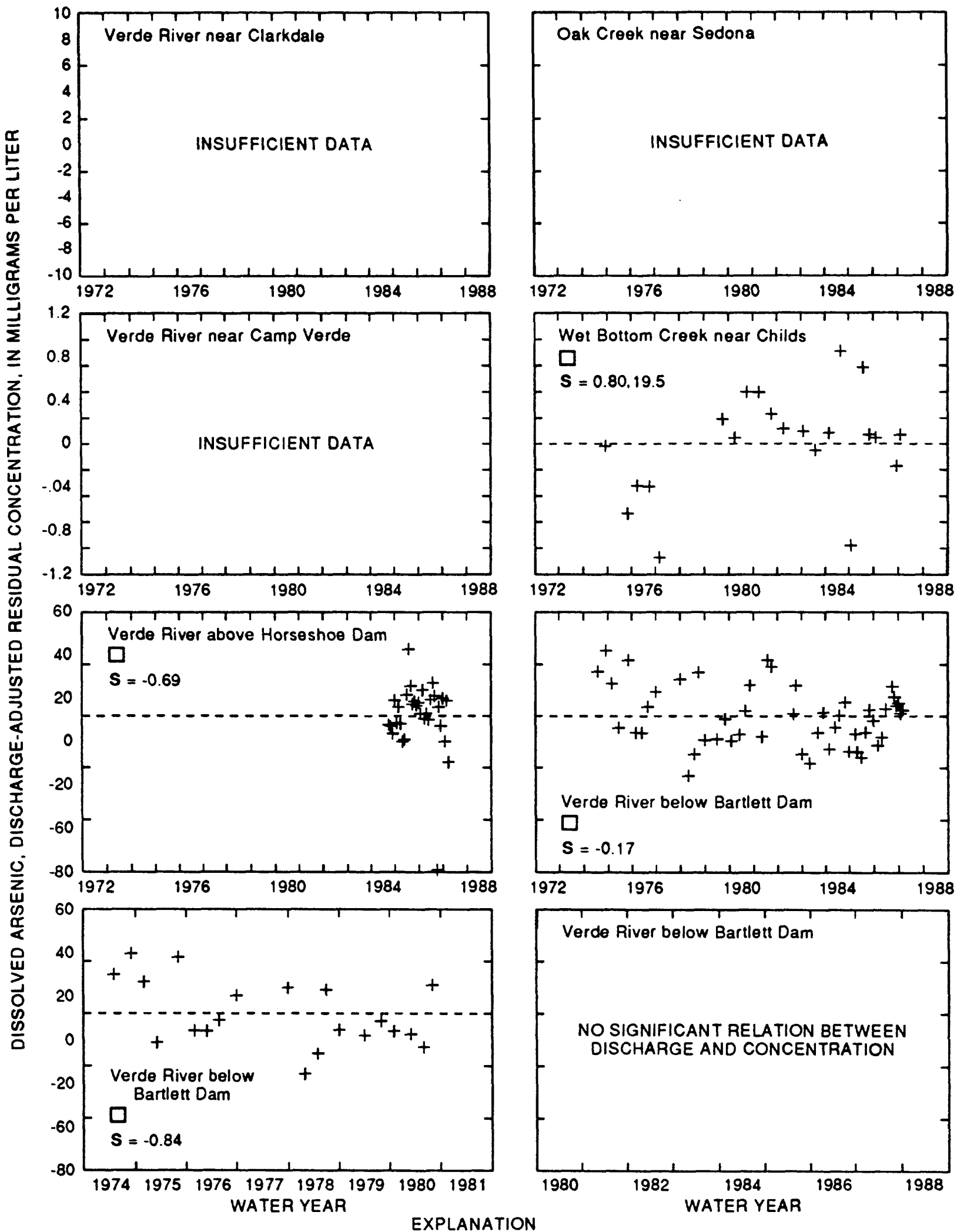

TREND-SIGNIFICANCE LEVEL, IN PERCENT:

Less than 95

EXPLANATION

- - LINE INDICATES MEDIAN CONCENTRATION VALUES

S TREND SLOPE IN MILLIGAAMS PER LITER. WHERE VARYING RATE OF CHANGE WAS COMPUTED. TWO VALUES ARE GIVEN: FIRST VALUE IS CHANGE FOR I YEAR AND SECOND VALUE IS CHANGE OVER SAMPLE COLLECTION PERIOD

Figure 9.-Temporal trends in discharge-adjusted dissolved-arsenic concentrations using the seasonal Kendall tau test. 

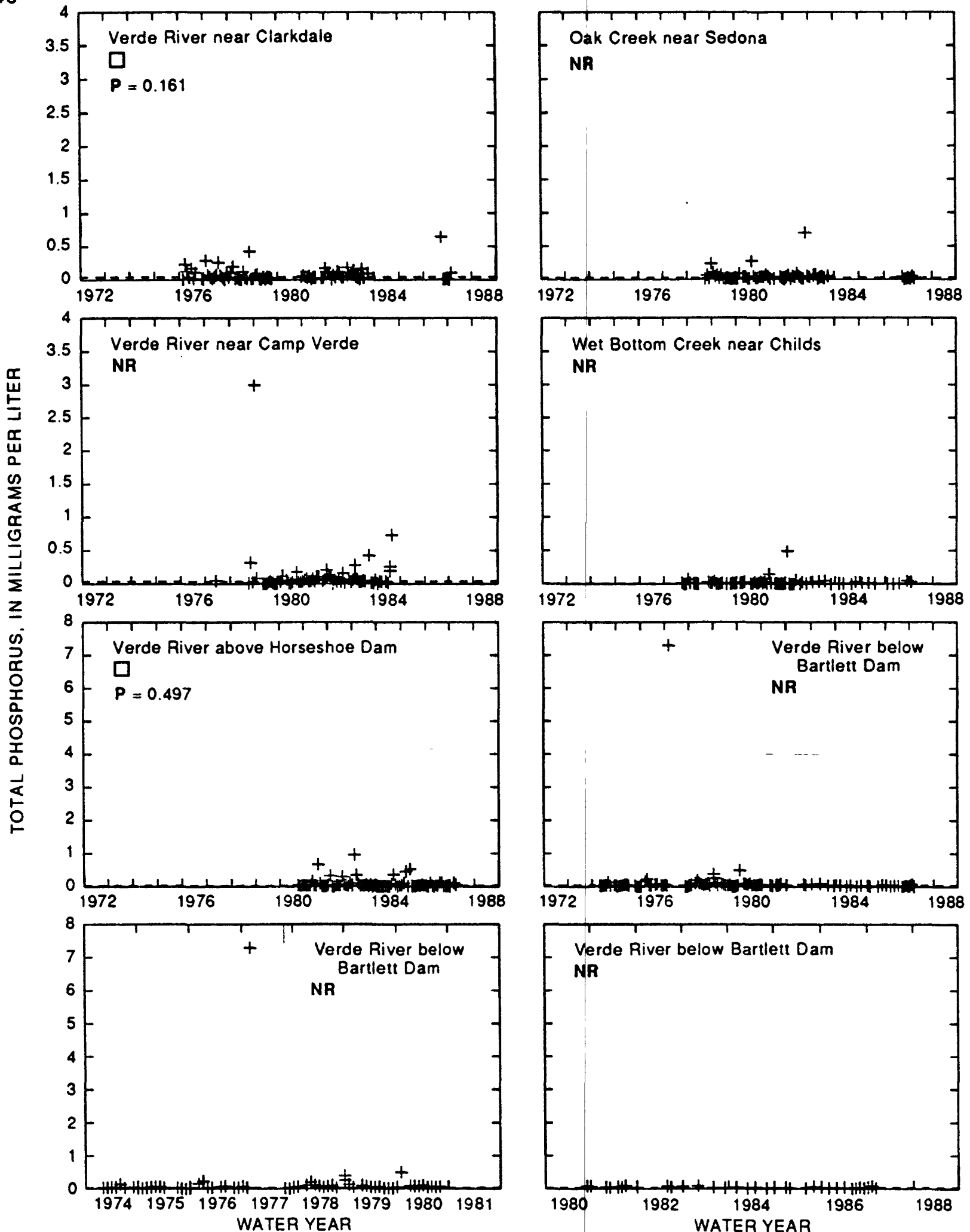

EXPLANATION

TREND-SIGNIFICANCE LEVEL, IN PERCENT: NR NO RELATION BETWEEN DISCHARGE AND CONCENTRATION
Less than 95
ID INSUFFICIENT DATA

P P VALUE OF THE VARIABLE TIME IN THE REGRESSION OF DISCHARGE AND TIME ON CONCENTRATION

- - - LINE INDICATES MEDIAN CONCENTRATION VALUES

Figure 10.-Temporal trends in total-phosphorus concentrations using the ordinary least-squares regression analysis. 
for December 1980 through March 1987 at Verde River below Bartlett Dam with a $p$ value of 0.0037 . The mean total-phosphorus concentration for the time period was $0.0436 \mathrm{mg} / \mathrm{L}$. With the decreasing trend, the median concentrations for this constituent are below the criteria of $0.10 \mathrm{mg} / \mathrm{L}$ that had been promulgated by the U.S. Environmental Protection Agency (1976) for streams flowing directly into lakes (fig. 11). OLS regression analysis for trend could be used on only two of the eight data sets for this constituent because of the lack of correlation between discharge and concentration.

\section{$\underline{p H}$}

Ordinary least-squares regression analysis (fig. 12) and seasonal Kendall tau test (fig. 13) of $\mathrm{pH}$ data at the six sites did not show major changes in hydrogen-ion activity. Seasonal Kendall tau tests of DAC pH data showed small increases in trend of 1 to 6 percent standard $\mathrm{pH}$ units per year for seven of the eight data sets ( $t a b l e ~ 5)$. The one exception was the analysis of DAC data for December 1980 to March 1987 at Verde River below Bartlett Dam, which showed a decrease of 0.001 standard pH units. Only the trend for 1950-87 at Verde River below Bartlett Dam was considered significant (1.86-percent change). The identified trend could be in error because of the inclusion of data collected at both sampling sites in the analysis. OLS regression analysis for the three upstream sites and for December 1980 to March 1987 at Verde River below Bartlett Dam found small increasing trends in $\mathrm{pH}$. These trends were not statistically significant and are not in violation of the State of Arizona criteria of a maximum allowable change of 0.5 standard $\mathrm{pH}$ units for water from the Verde River.

The percentage increase or decrease shown in table 5 could be applied to antilogarithm values of $\mathrm{pH}$ to determine the increase or decrease in hydrogen-ion activity in the water. For example, a 3.51-percent increase in the $\mathrm{pH}$ level of 8.30 at the Verde River near Camp Verde site would result in a decrease of hydrogen-ion concentration of $0.0155 \mathrm{pH}$ units for a final $\mathrm{pH}$ value of 8.3155 standard units. Values of $\mathrm{pH}$ are reported as the negative base 10 logarithm of the hydrogen-ion activity in moles per liter (Hem, 1985, p. 61).

\section{Total Nitrite Plus Nitrate-Nitrogen}

Analyses of total nitrite plus nitrate-nitrogen data did not show trends indicative of point or nonpoint pollution sources contributing water containing large concentrations of the constituent into the Verde River system (table 5). Few samples were determined to have concentrations of total nitrite plus nitrate-nitrogen greater than $0.5 \mathrm{mg} / \mathrm{L}$ (fig. 14 ). Concentrations of the constituent were smaller at the Oak Creek near Sedona site than at the other sites and no trend was indicated using the two methods of analyses. A value for the calculated trend per year for Oak Creek near Sedona was not entered in table 5 for the seasonal Kendall tau test or shown on figure 15 because several of the sample values were reported as having concentrations of "less than" $0.10 \mathrm{mg} / \mathrm{L}$.

Analysis of data for concentrations of total nitrite plus nitrate-nitrogen using the seasonal Kendall tau test on DAC data did not 

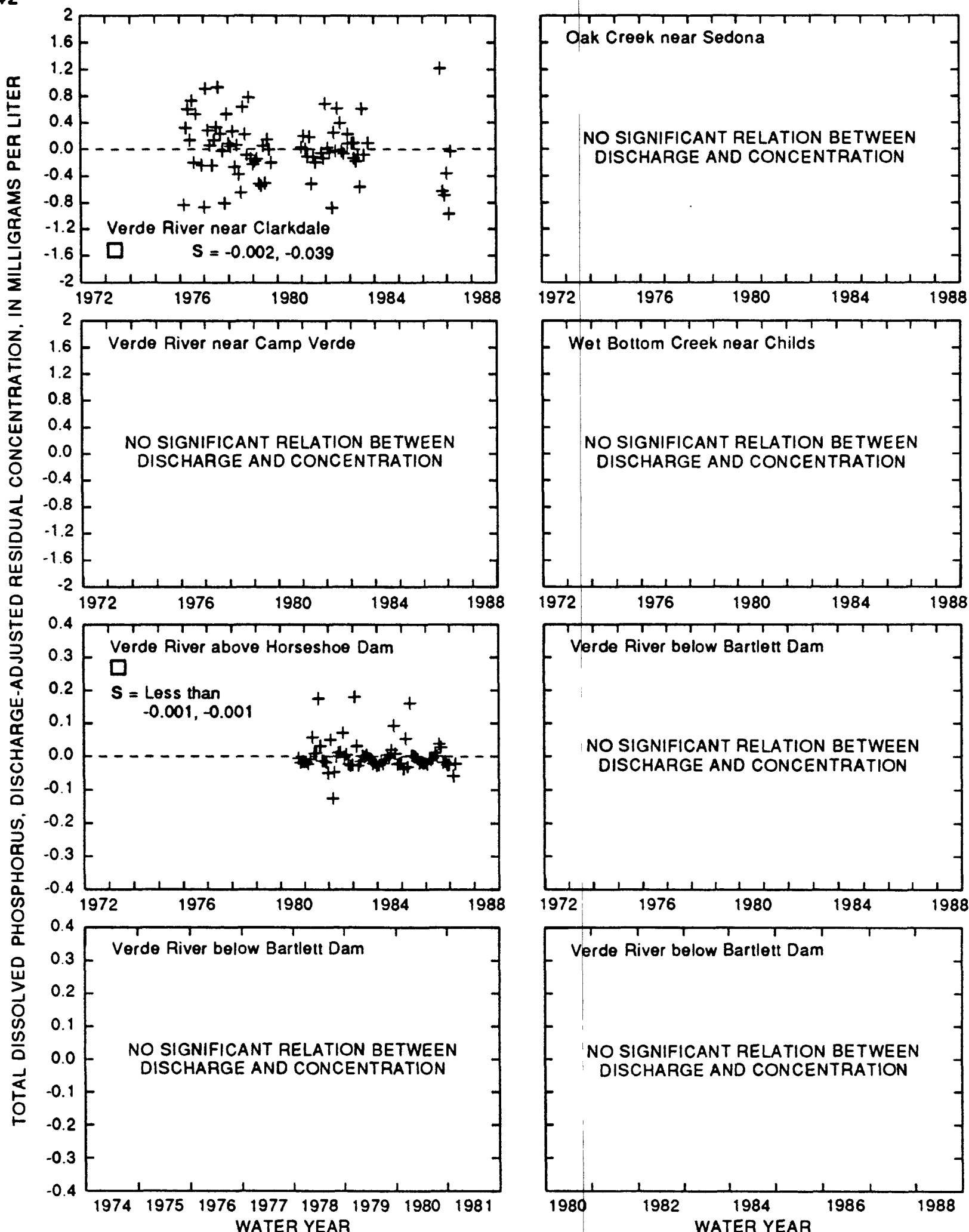

EXPLANATION

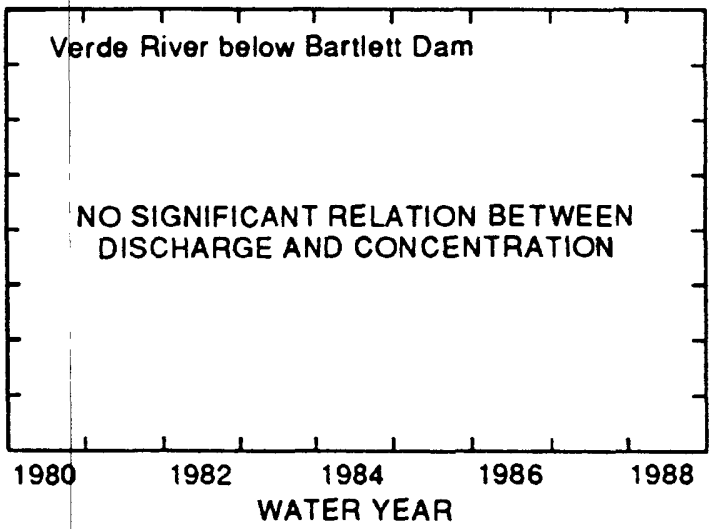

TREND-SIGNIFICANCE LEVEL, IN PERCENT: Less than 95 LINE INDICATES MEDIAN CONCENTRATION VALUES

$S$ TREND SLOPE IN MILLIGRAMS PER LITER. WHERE VARYING RATE OF CHANGE WAS COMPUTED, TWO VALUES ARE GIVEN; FIRST VALUE IS CHANGE FOR I YEAR AND SECOND VALUE IS CHANGE OVER SAMPLE COLLECTION PERIOD

Figure 11.-Temporal trends in discharge-adjusted total-phosphorus concentrations using the seasonal Kendall tau test. 

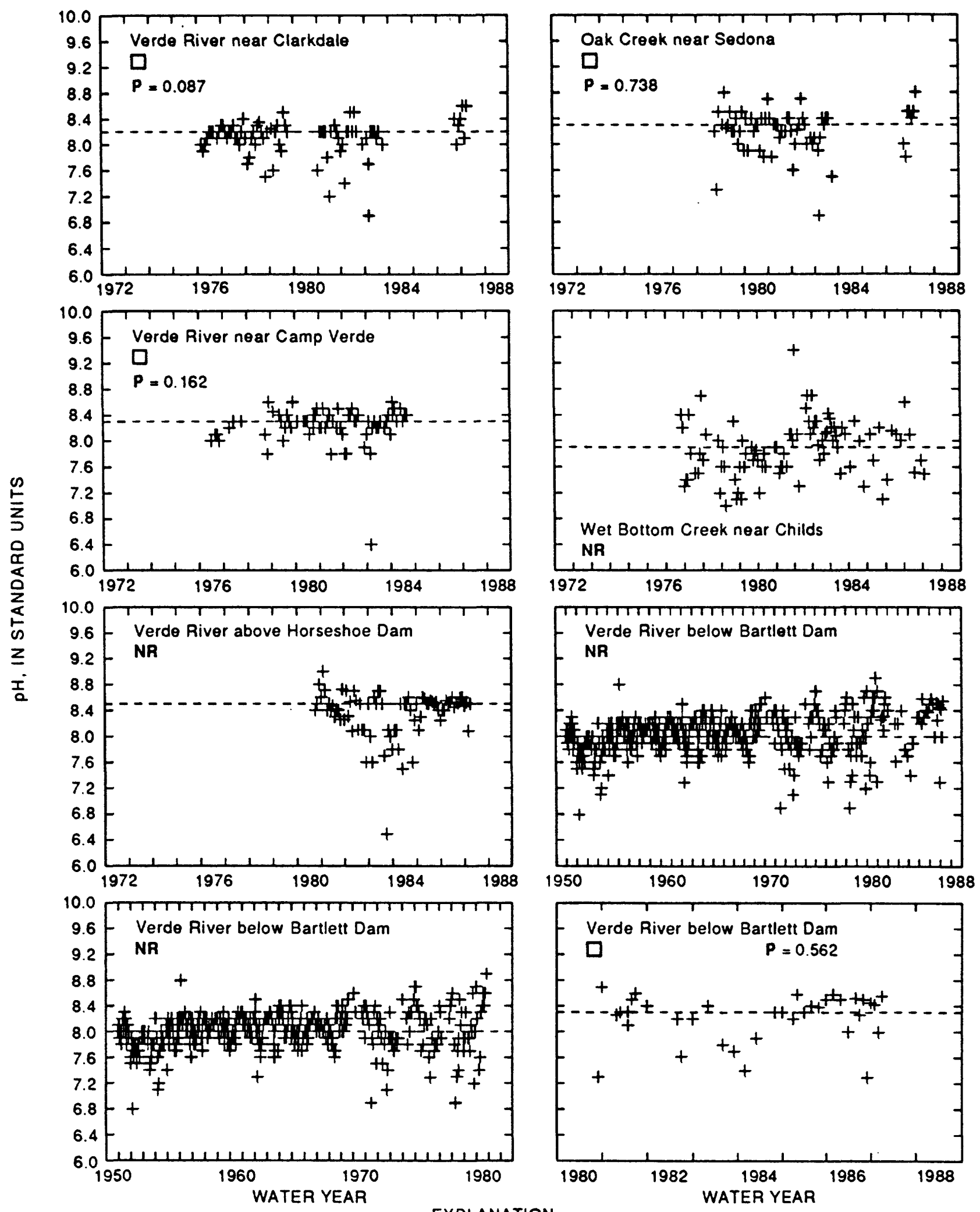

TREND-SIGNIFICANCE LEVEL, IN PERCENT:

EXPLANATION

Less than 95

NR NO RELATION BETWEEN DISCHARGE

P P Value of the Variable time in the Regression of DISCHARGE AND TIME ON CONCENTRATION

AND CONCENTRATION

- - LINE INDICATES MEDIAN CONCENTRATION VALUES

Figure 12.-Temporal trends in $\mathrm{pH}$ concentrations using the ordinary least-squares regression analysis. 

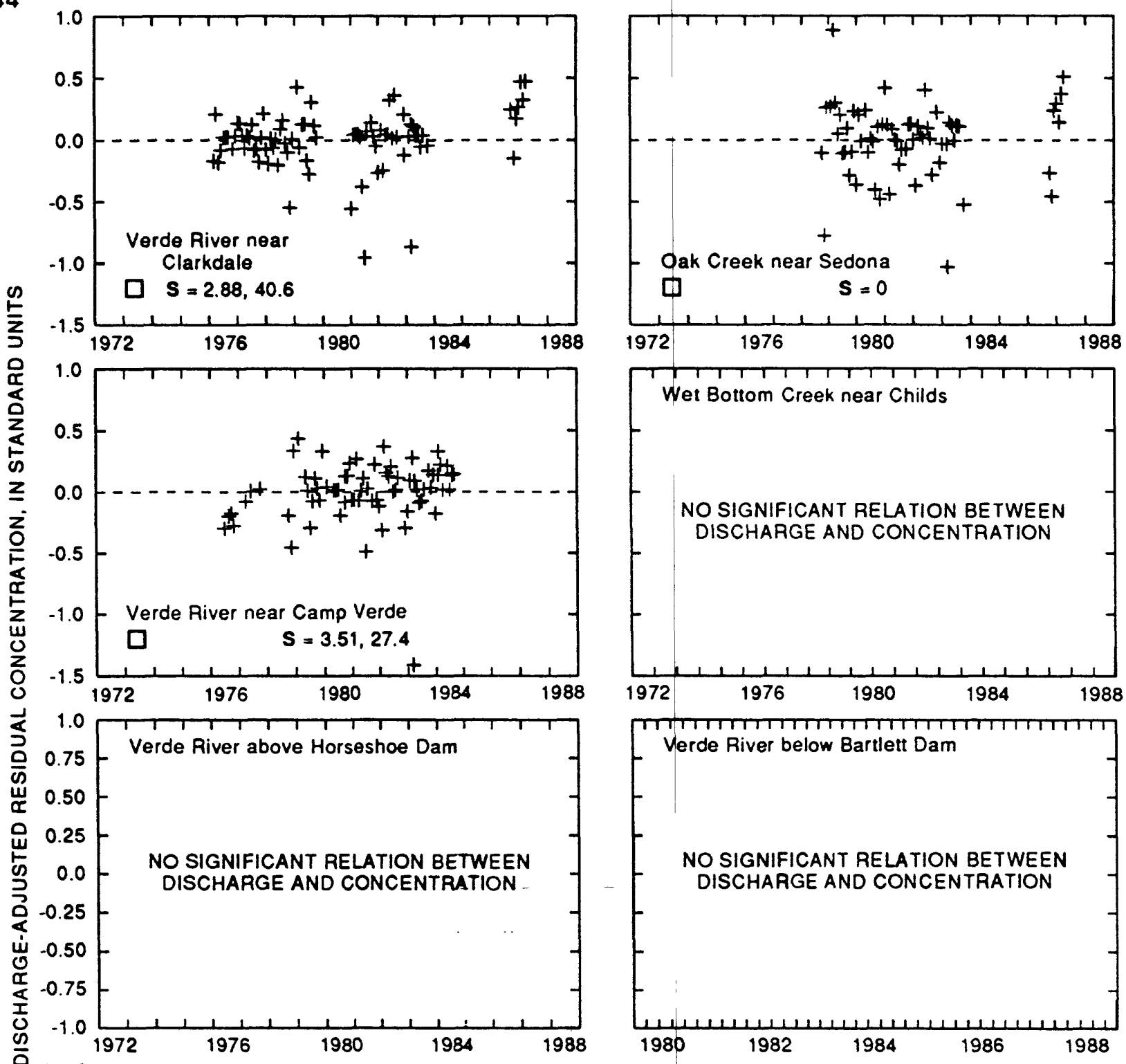

要
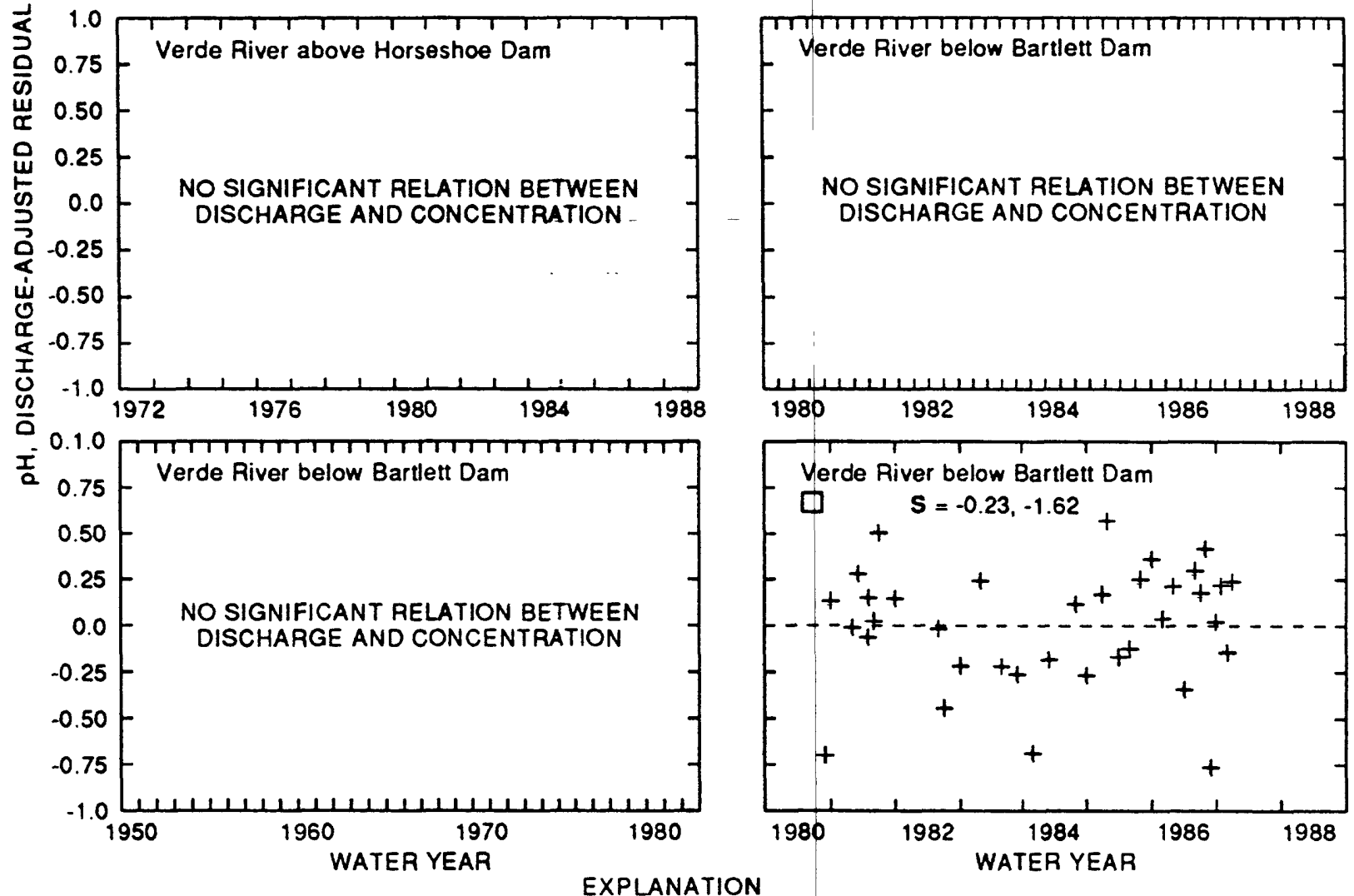

TREND-SIGNIFICANCE LEVEL, IN PERCENT:

Less than 95

- - LINE INDICATES MEDIAN CONCENTRATION

S TREND SLOPE IN MILLIGRAMS PER LITER. WHERE VARYING RATE OF CHANGE WAS COMPUTED. TWO VALUES ARE GIVEN; FIRST VALUE IS CHANGE FOR I YEAR AND SECOND VALUE IS CHANGE OVER SAMPLE COLLECTION PERIOD

Figure 13.-Temporal trends in discharge-adjusted $\mathrm{pH}$ concentrations using the seasonal Kendall tau test. 

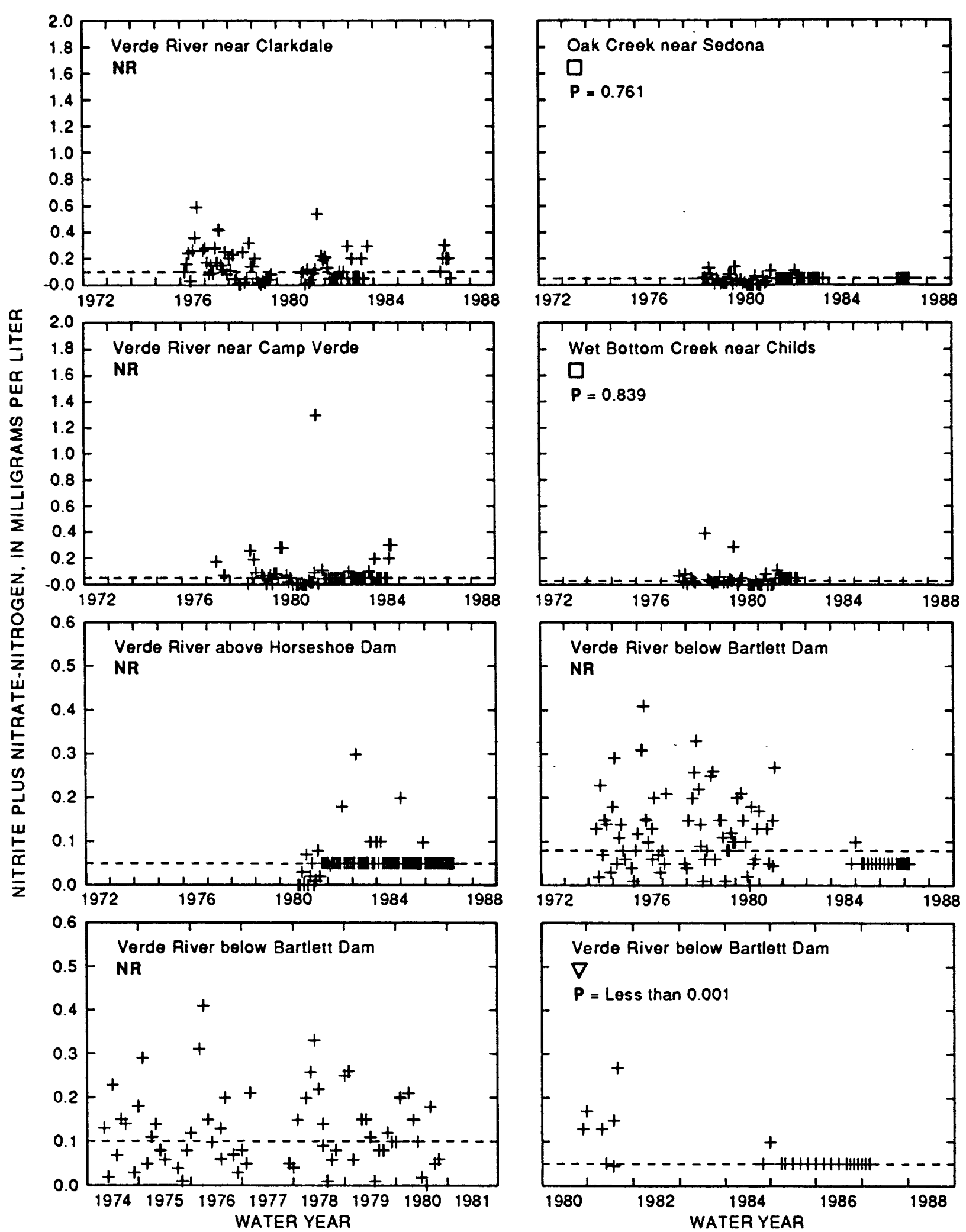

EXPLANATION

TREND-SIGNIFICANCE LEVEL, IN PERCENT:

$\nabla$ Greater than 95, triangle orientation indicates trend direction

NR NO RELATION BETWEEN DISCHARGE AND CONCENTRATION

Less than 95

$P$ P VALUE OF THE VARIABLE TIME IN THE REGRESSION OF DISCHARGE AND TIME ON CONCENTRATION

- - LINE INDICATES MEDIAN CONCENTRATION VALUES

Figure 14.-Temporal trends in total nitrite plus nitrate-nitrogen concentrations using the ordinary least-squares regression analysis. 

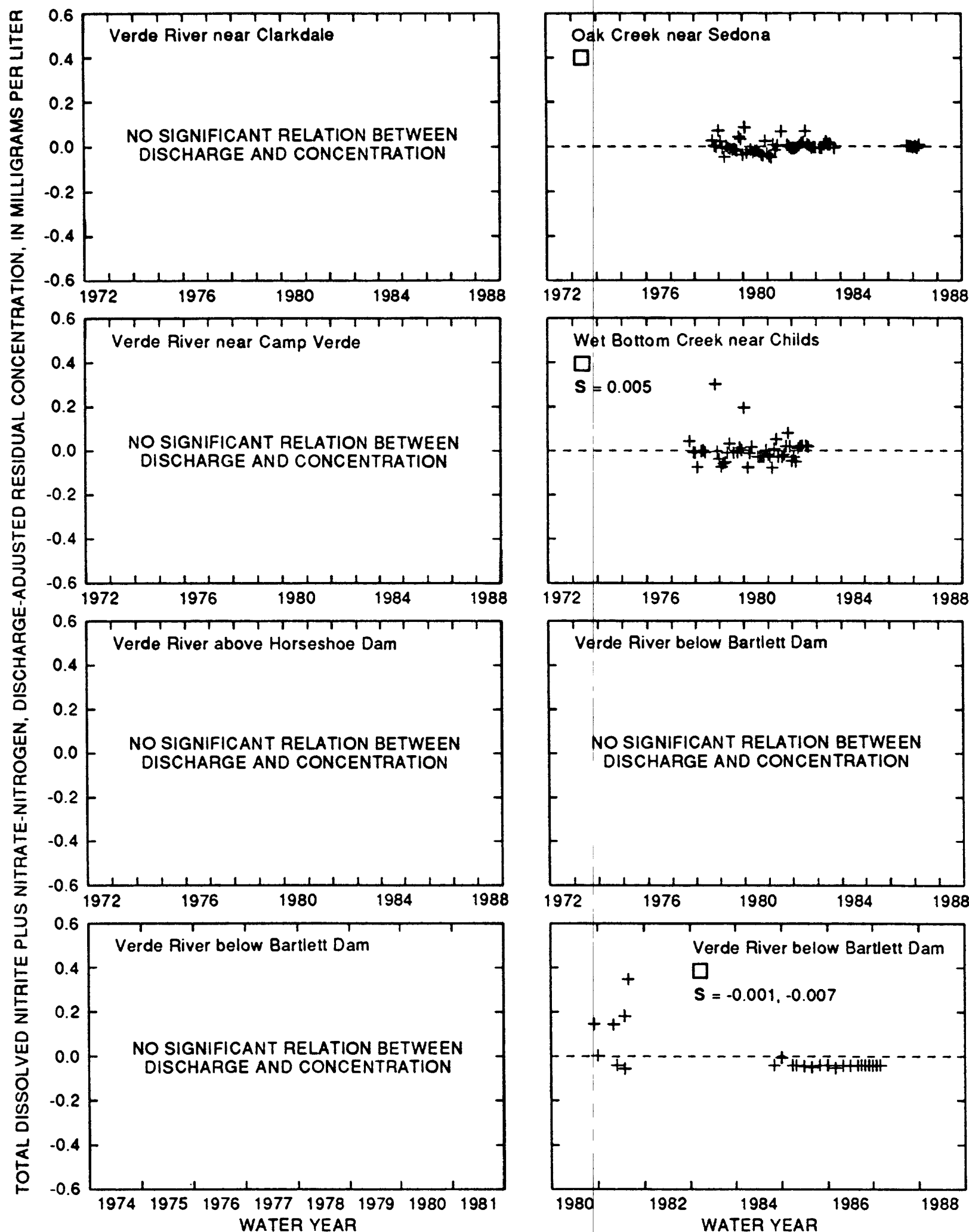

TREND-SIGNIFICANCE LEVEL, IN PERCENT:

EXPLANATION

Less than 95

S TREND SLOPE IN MILLIGRAMS PER LITER. WHERE VARYING RATE OF CHANGE WAS COMPUTED, TWO VALUES ARE GIVEN: FIRST VALUE IS CHANGE FOR 1 YEAR AND SECOND VALUE LINE INDICAT

IS CHANGE OVER SAMPLE COLLECTION PERIOD

Figure 15.-Temporal trends in discharge-adjusted total nitrite plus nitrate-nitrogen concentrations using the seasonal Kendall tau test. 
find a significant trend at the study sites (fig. 15). The Verde River near Camp Verde site, where analyses could have identified nitrogen entering the river from septic tanks or agricultural sources in verde valley, had zero-magnitude trend ( $t a b l e ~ 5)$. The seasonal Kendall tau test for trend at this site used concentration data adjusted with the mean concentration value determined for the site.

OLS regression analysis could be used on only three data sets. The coefficient-of-determination values for the ols regressions were less than 0.20. A significant decreasing trend in nitrogen of 0.013 was calculated from data collected at Verde River below Bartlett Dam from 1980 to 1987. The calculation of the small decrease in trend was influenced by five samples collected in 1981 (fig. 14).

\section{Dissolved Iron}

Trend analysis of dissolved-iron concentration data did not show Increasing trends at sites where man's activities in the basin, for example mining activities, could have caused an increasing trend. OLs regression analysis of data collected at the Wet Bottom Creek near Childs site, the site most unaffected by man's activities, identified a significant increasing trend ( $f 1 g$. 16). An increasing trend in dissolved-iron concentrations of $2.57(\mu \mathrm{g} / \mathrm{L}) / \mathrm{yr}$ to $61.6 \mu \mathrm{g} / \mathrm{L}$ over the period of record from the seasonal Kendall tau test on DAC data was indicated at this site (fig. 17). Although an increasing trend is present at Wet Bottom Creek, the SMCL $(0.3 \mathrm{mg} / \mathrm{L})$ for drinking water promulgated by the Environmental Protection Agency for total-iron concentrations does not appear to approach being exceeded. Trends in dissolved-iron concentrations determined from the seasonal Kendall tau test on DAC data vary at the other sites with a range of $-3.18(\mu \mathrm{g} / \mathrm{L}) / \mathrm{yr}$ at Verde River near Clarkdale to $3.71(\mu \mathrm{g} / \mathrm{L}) / \mathrm{yr}$ at 0 ak Creek at Red Rock Crossing, neither of which was statistically significant. Decreasing trends were measured for all three data periods at the Verde River below Bartlett Dam site with the trend for the 1968-87 period, -1.12 $(\mu \mathrm{g} / \mathrm{L}) / \mathrm{yr}$, being statistically significant. OLS regression analysis found results that were similar to those from the seasonal Kendall tau test at the five upstream sites of the study (table 5). The $p$ value calculated for data for the Wet Bottom Creek site also showed a statistically significant increasing trend.

\section{Fecal-Coliform Bacteria}

The results of the OLS regression analysis and the seasonal Kendall tau test on fecal-coliform bacteria data did not show significant decreasing or increasing trends in the study area. The results of the ols regression analysis on data collected at Oak Creek near Sedona surprisingly did not show that a trend exists (fig. 18). Results of the seasonal Kendall tau test on DAC data showed a slight decrease of less than 0.4 (colonies/100 ml)/yr (colonies per 100 milliliters per year) at a $p$ value of 0.7605 ( $\mathrm{fig} .19$ ). Before regulations aimed at reducing concentrations were implemented, water-quality standards for fecal-coliform bacteria were exceeded for the stream reach near sedona during periods of low flow on 

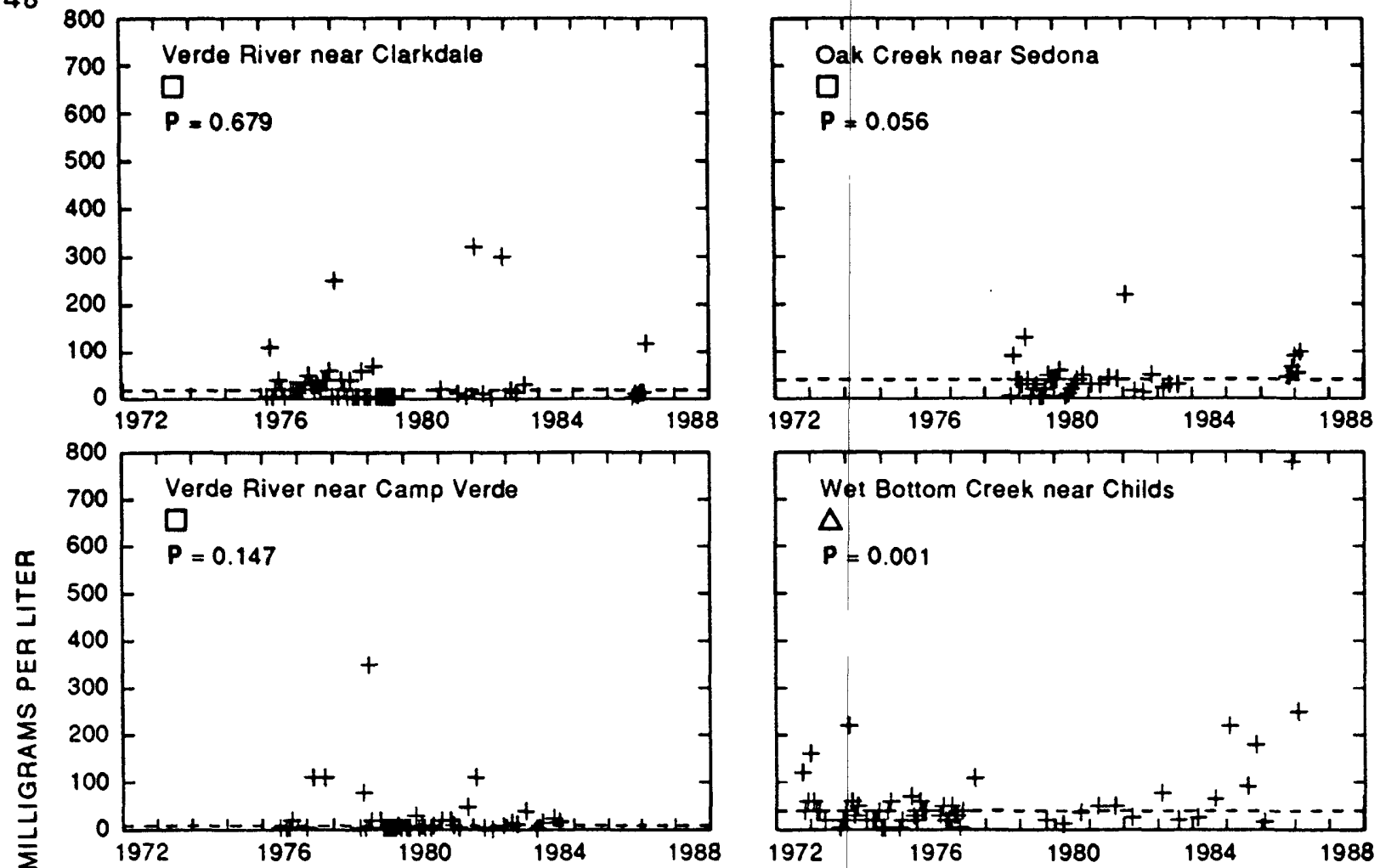

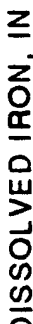
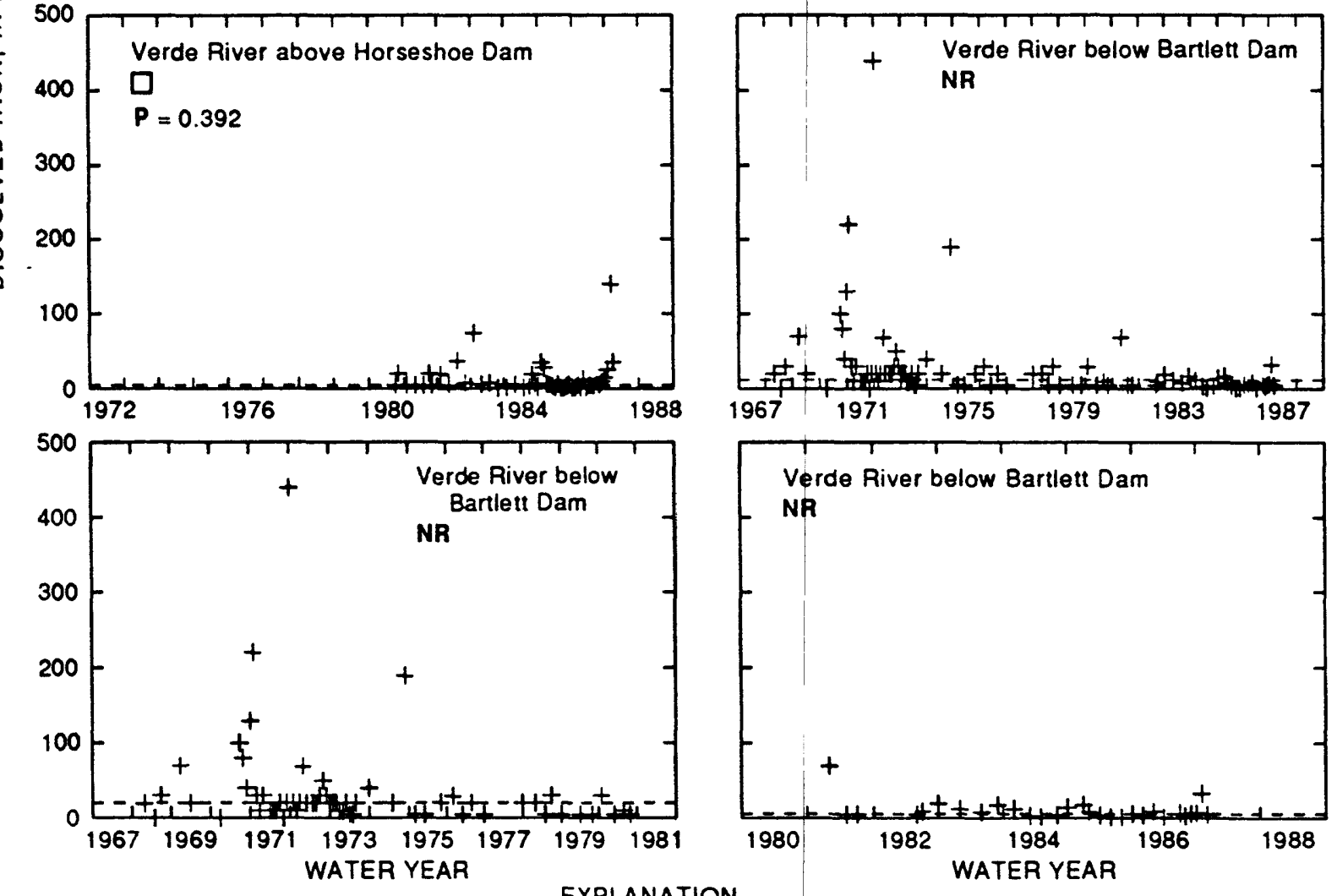

EXPLANATION

TREND-SIGNIFICANCE LEVEL, IN PERCENT:

$\nabla$ Greater than 95, triangle orientation indicates trend direction

Less than 95
NR NO RELATION BETWEEN DISCHARGE AND CONCENTRATION

$P$ P VALUE OF THE VARIABLE TIME IN THE REGRESSION OF DISCHARGE AND TIME ON CONCENTRATION

- - LINE INDICATES MEDIAN CONCENTRATION VALUES

Figure 16.-Temporal trends in dissolved-iron concentrations using the ordinary least-squares regression analysis. 

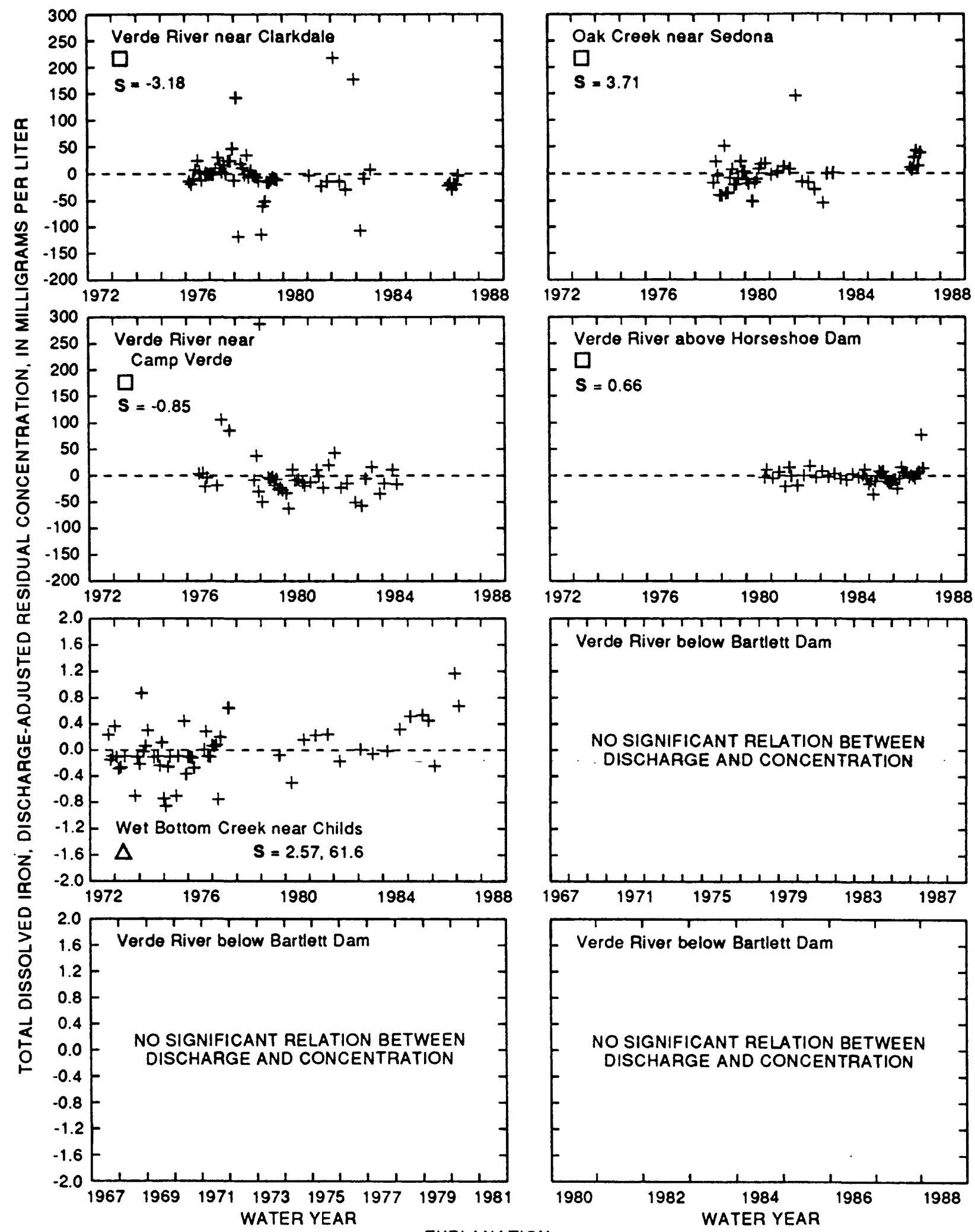

TREND-SIGNIFICANCE LEVEL, IN PERCENT: S TREND SLOPE IN MILLIGRAMS PER LITER. WHERE VARYING Less than 95

LINE INDICATES MEDIAN CONCENTRATION VALUES FIRST VALUE IS CHANGE FOR 1 YEAR AND SECOND VALUE IS CHANGE OVER SAMPLE COLLECTION PERIOD

Figure 17.-Temporal trends in discharge-adjusted dissolved-iron concentrations using the seasonal Kendall tau test. 

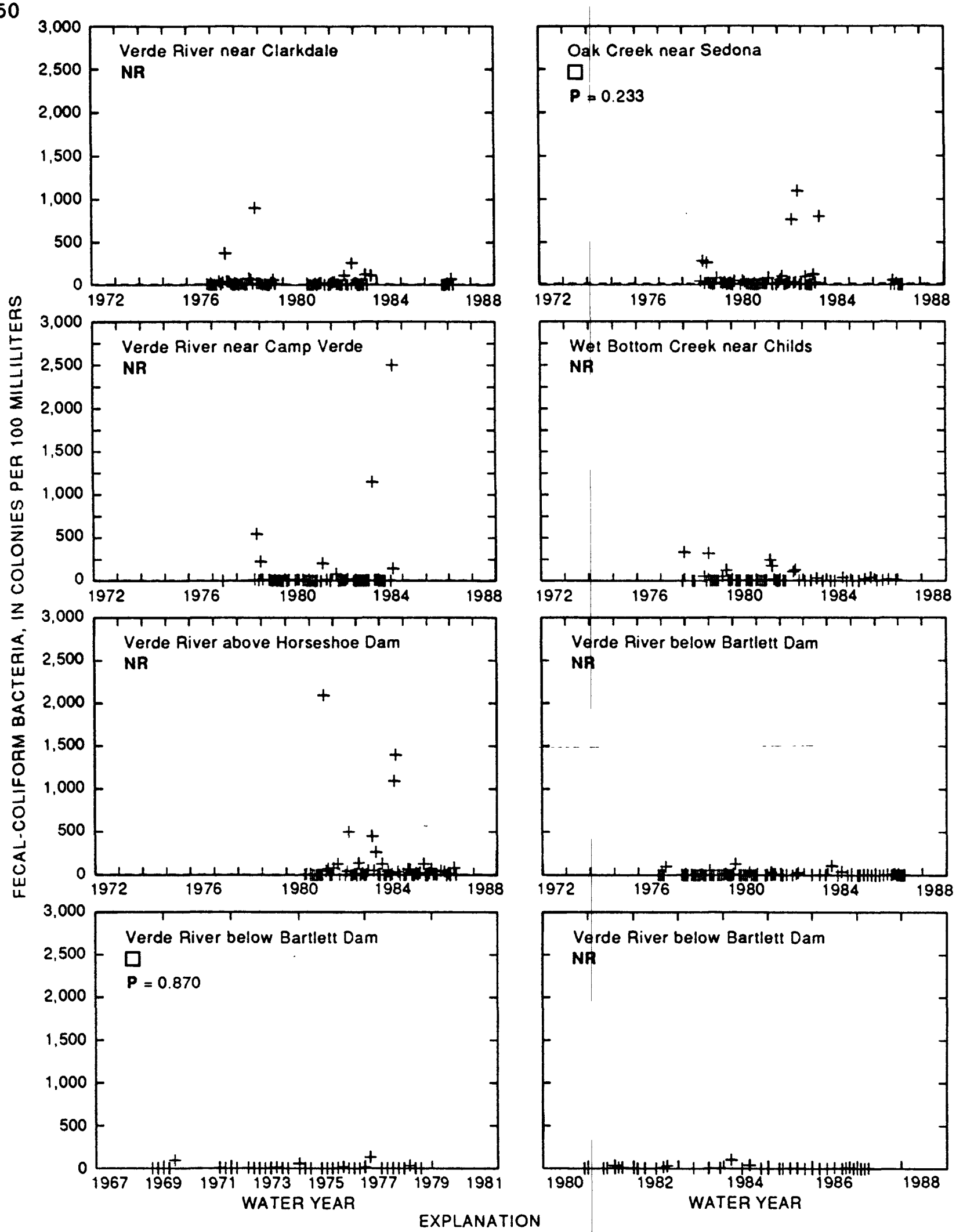

TREND-SIGNIFICANCE LEVEL, IN PERCENT: NR NO RELATION BETWEEN DISCHARGE AND CONCENTRATION Less than 95

$P$ P VALUE OF THE VARIABLE TIME IN THE REGRESSION OF LINE INDICATES MEDIAN CONCENTRATION DISCHARGE AND TIME ON CONCENTRATION VALUES

Figure 18.-Temporal trends in fecal-coliform bacteria concentrations using the ordinary least-squares regression analysis. 

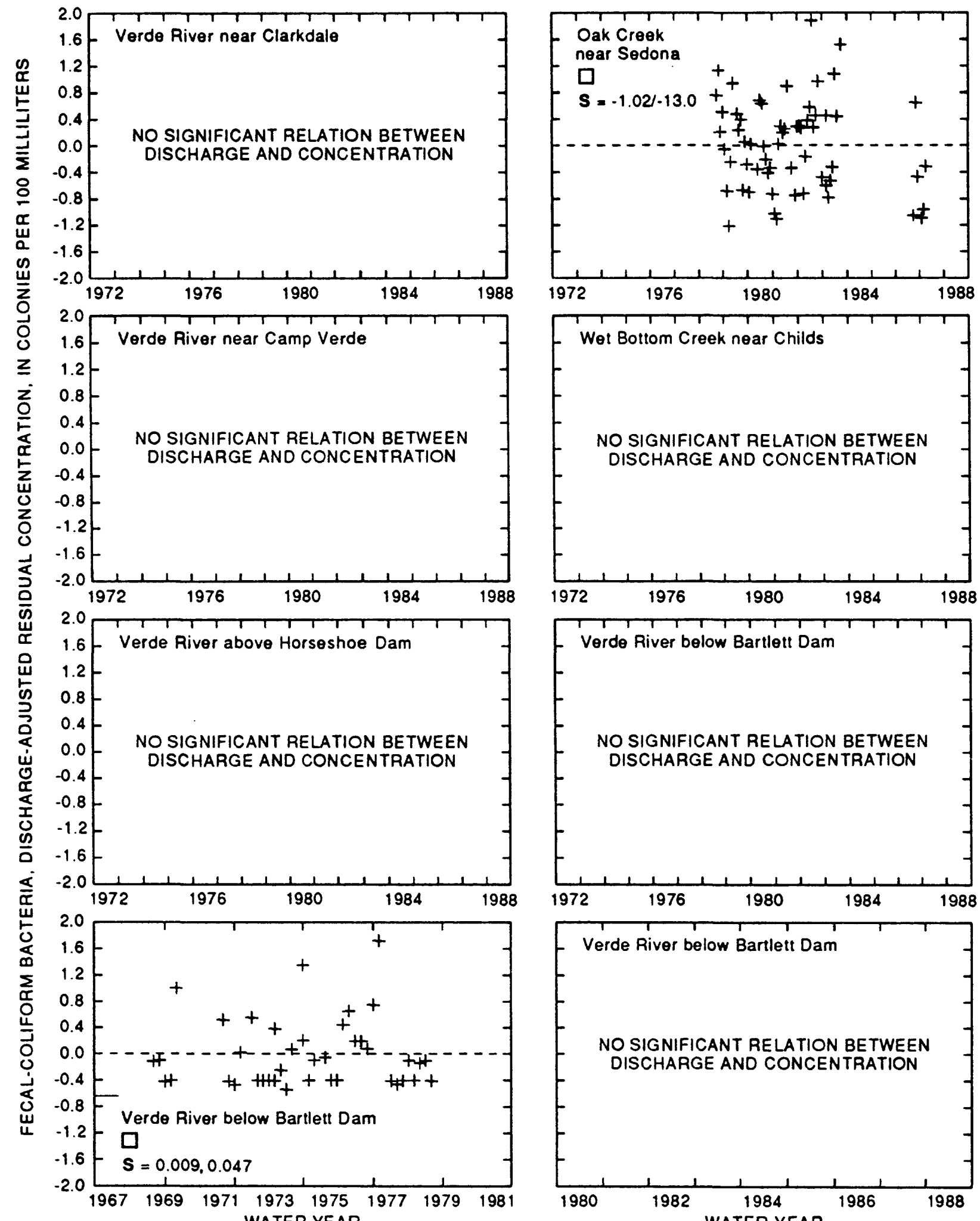
WATER YEAR

\section{EXPLANATION}

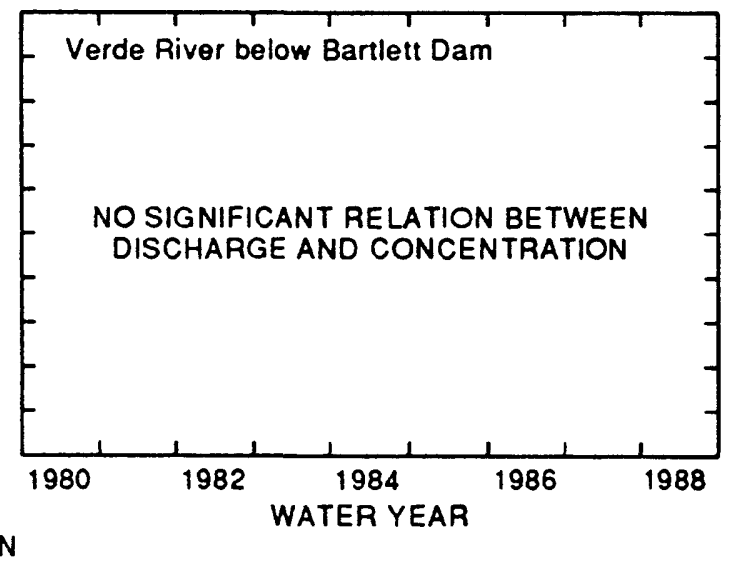

TREND-SIGNIFICANCE LEVEL. IN PERCENT: Less than 95

LINE INDICATES MEDIAN CONCENTRATION VALUES

S TREND SLOPE IN MILLIGRAMS PER LITER. WHERE VARYING RATE OF CHANGE WAS COMPUTED. TWO VALUES ARE GIVEN: FIRST VALUE IS CHANGE FOR 1 YEAR AND SECOND VALUE IS CHANGE OVER SAMPLE COLLECTION PERIOD 
summer weekends when large-scale recreational use occurred (Julie E. Tupper, hydrologist, Coconino National Forest, oral commun., 1990). The infrequency in data collection at this site and the time of sampling (generally on a weekday) could be a possible explanation why the seasonal Kendall tau test on DAC data did not show any trend in fecal-coliform bacteria concentrations. Additional sampling of Oak Creek during periods of high recreational use is necessary to verify the existence or lack of a trend.

\section{SUMMARY AND CONCLUSIONS}

Detection of statistically significant increasing trends of 6.89 milligrams per liter per year (mg/L)/yr of dissolved-solids concentrations using the seasonal Kendall tau test on discharge-adjusted concentrations data at the Verde River near Camp Verde site could indicate the emergence of inorganic water-quality problems on a local basis. An increasing trend, $3.59(\mathrm{mg} / \mathrm{L}) / \mathrm{yr}$ of dissolved-sulfate concentrations at a $\mathrm{p}$ value of 0.2690 , was calculated at the Verde River near Camp Verde site. Analysis of data collected at sites downstream indicated a reduction in concentrations of these two constituents of almost equal amounts; therefore, the increasing trends for these two constituents do not appear to be basinwide. The mean dissolved-sulfate concentration at the Camp Verde site, $95.4 \mathrm{mg} / \mathrm{L}$, is within the levels for drinking water promulgated by the U.S. Environmental Protection Agency and the State of Arizona. The mean dissolved-solids concentration of $403 \mathrm{mg} / \mathrm{L}$ at the Camp Verde site is within levels for drinking water promulgated by the U.S. Environmental Protection Agency.

Increasing trends of dissolved-iron concentrations were found at the two sites on tributaries to the Verde River but not at sites on the main stem. The increases of $3.7(\mu \mathrm{g} / \mathrm{L}) / \mathrm{yr}$ (micrograms per 1iter per year) at Oak Creek near Sedona and $2.57(\mu \mathrm{g} / \mathrm{L}) / \mathrm{yr}$ at Wet Bottom Creek near Childs are reflected in the largest mean dissolved-iron concentrations of the study sites. The comparisons of the average yearly increase and the mean dissolved-iron concentrations at each site with the criteria promulgated by the U.S. Environmental Protection Agency for drinking water do not indicate the emergence of inorganic water-quality problems.

Analyses of the data collected at the six study sites do not show indications of point-source or nonpoint releases, with the possible exception of the reach between the clarkdale and Camp Verde sampling sites. Few extreme constituent values above limits recommended by the U.S. Environmental Protection Agency for drinking| water and the State of Arizona for drinking water and other uses were found in the data set; maximum contamintant levels (MCL) and maximum allowable limits (MAL) criteria generally were exceeded only once or twice per constituent at individual sites.

A source of water that contains large concentrations of dissolved solids and sulfate exists between the two main stem Verde River sites at Clarkdale and Camp Verde. The increasing trend in dissolved sulfate and dissolved solids at Camp Verde for 1976-84, in conjunction with the decreasing trend of the same constituents downstream at the Verde River 
above Horseshoe Dam site for 1980-87, could indicate that a change in direction of trend from increasing to decreasing occurred. This change may have been brought about by a natural change in the water-quality characteristics of the Verde River; however, because of the lack of concurrent data-collection periods, this conclusion cannot be substantiated. Data collection at the Verde River near Camp Verde site would need to be resumed in order to evaluate these trends. Sample collection of the Verde River at intermittent points between the Clarkdale and Camp Verde sites would lend insight to the source of water that contained large concentrations of dissolved solids and sulfate.

Before the seasonal Kendall tau test was applied, data collected during a water year was separated into 12 monthly increments. For constituents collected less than monthly, sampling time need to be varied yearly to optimize the efficiency of the sampling program and the seasonal Kendall tau test. For example, if six arsenic samples are collected bimonthly, alternate months would be used in successive years.

The mean concentrations of the eight constituents determined from samples collected at the study sites are within limits for drinking water set by the U.S. Environmental Protection Agency and the State of Arizona, except for total phosphorus. The only reach of the river where water quality appears to be degrading is between the Clarkdale and Camp Verde sampling sites, where increasing trends in dissolved-solids and dissolvedsulfate concentrations were calculated. The discontinuance of the sampling site at Camp Verde prevents the conclusion that the increasing trends of these constituents could have ended and the direction of the trend changed as indicated by data collected at the next site downstream, Verde River above Horseshoe Dam. To better understand the hydrologic system of the reach of the Verde River between the Verde River near Clarkdale site and the Verde River above Horseshoe Dam site, two actions could be taken. The sampling site at Verde River near Camp Verde could be reinstated to provide concurrent water-quality data at study sites in the Verde Valley. Seepage runs and water-quality sampling would be done at selected points between the Camp Verde and Clarkdale sites and at selected inflow points between the two sites to provide valuable hydrologic information.

\section{SELECTED REFERENCES}

Alley, W.M., 1987 , A note on stagewise regression: The American statistician, May 1987, v. 41, no. 2, p. 132-134.

1988, Using exogenous variables in testing for monotoxic trends in hydrologic time series: Water Resources Research, November 1988, v. 24, no. 11, p. 1955-1961.

Arizona Secretary of State, 1987, Water quality, boundaries and standards, Title 18, R-18-101 through 304: Phoenix, Arizona, p. 1-37.

Arizona Atomic Energy Commission, 1977, Rules and regulations, Title 12: Phoenix, Arizona, State of Arizona report, Supplement 77-3, p. $1-133$. 
Buell, G.R., and Grams, S.C., 1985, The hydrologic bench-mark program-A standard to evaluate time-series trends in selected water-quality constituents for streams in Georgia: U.S. Geological Survey Water-Resources Investigations Report 84-4318, 36 p.

Goetz, C.L., Abeyta, C.G., and Thomas, E.V., 1987, Application of techniques to identify coal-mine and power-generation effects on surfacewater quality, San Juan River basin, New Mexico and Colorado: U.S. Geological Survey Water-Resources Investigations Report $86-4076,79 \mathrm{p}$.

Helsel, D.R., and Cohn, T.A., 1988, Estimation of descriptive statistics for multiple censored water quality data: Water Resources Research, December 1988, v. 24, no. 12, p. 1997-2004.

Hem, J.D., 1985, Study and interpretation of the chemical characteristics of natural water: U.S. Geological Survey Water-Supply Paper 2254 , $263 \mathrm{p}$.

Hirsch, R.M., 1981, Techniques of trend analysis for monthly water-quality data: U.S. Geological Survey Open-File Report $81-488,30 \mathrm{p}$.

Hjalmarson, H.W., and Davidson E.S., 1966, Anticipated changes in the flow regimen caused by the addition of water to the East Verde River, Arizona: Arizona State Land Department Water-Resources Report 28, $10 \mathrm{p}$.

Iman, R.L., and Conover, W.J., 1983, A modern approach to statistics: New York, Wiley and Sons, 497 p.

Kendall, M.G., 1975, Rank correlation methods: London, Charles Griffin and Company, $202 \mathrm{p}$.

McClennan, J.J., 1984, Official compilation of administrative rules and regulations: Phoenix, Arizona, State of Arizona report, Supplement $84-3$, p. $68-84$.

1986, Official compilation of administrative rules and regulations: Phoenix, Arizona, State of Arizona report, Advance Supplement $86-4$, p. 1-49.

McLeod, A.I., Hipe1, K., and Camancho, F., 1984, Trend assessment of water quality time series: Water Resources Bulletin 19, p. 537-547.

Owen-Joyce, S.J., 1984, Hydrology of a stream-aquifer system in the Camp Verde area, Yavapai County, Arizona: Arizona Department of Water Resources Bulletin 3, $60 \mathrm{p}$.

Owen-Joyce, S.J., and Bell, C.K., 1983, Appraisal of water resources in the upper Verde River area, Yavapai and Coconino Counties, Arizona: Arizona Department of Water Resources Bulletin 2, 219 p.

Sellers, W.D., Hill, R.H., and Sanderson-Rae, Margaret, eds., 1985, Arizona climate-The first hundred years: Tucson, University of Arizona Press, $143 \mathrm{p}$. 
Smith, R.A., Hirsch, R.M., and Slack, J.R., 1982, A study of trends in total phosphorus measurements at NASQAN stations: U.S. Geological Survey Water-Supply Paper 2190, 34 p.

Smith, R.A., Alexander, R.B., and Wolman, M.G., 1987, Analysis and interpretation of water-quality trends in major U.S. rivers, 1974-81: U.S. Geological Survey Water-Supply Paper 2307, 25 p.

U.S. Environmental Protection Agency, 1976, Quality criteria for water: U.S. Environmental Protection Agency, 256 p.

1986, Quality criteria for water, 1986: EPA 440/5-86-001, v.p.

1990, Drinking water regulations and health advisories: U.S. Environmental Protection Agency, Office of Drinking Water, $10 \mathrm{p}$.

Valley National Bank, 1988, Arizona statistical review: Phoenix, Valley National Bank of Arizona, 44th edition, $89 \mathrm{p}$.

Wilson, E.D., Moore, R.T., and Cooper, J.R., 1969, Geological map of Arizona: Arizona Bureau of Mines map, scale, 1:500,000. 